INSTITUTO DE PESQUISAS ENERGÉTICAS E NUCLEARES Autarquia associada à Universidade de São Paulo

SÍNTESE DE ZEÓLITAS E WOLASTONITA À PARTIR DA CINZA DA CASCA DO ARROZ

ALBERTO DE ANDRADE FERNANDES

Tese apresentada como parte dos requisitos para obtenção do grau de doutor em Ciências na Área de Tecnologia Nuclear-Materiais.

Orientador:

Prof. Dr. Humberto Gracher Riella

SÃO PAULO

2006 


\section{AGRADECIMENTOS}

- Aos meus pais.

- Ao meu filho Murilo e minha mulher Cristina.

- Ao IPEN por propiciar a realização deste trabalho.

- Ao Cnpq pela bolsa de Doutorado (processo n¹41311/2002-9).

- A orientação do Dr. Humberto Gracher Riella.

- A Dr ${ }^{a}$. Elita Urano Frajndlich pelo apoio no uso das instalações do MCR (Ipen).

- Ao Dr. Afonso Rodrigues de Aquino pela ajuda na revisão do texto.

- Ao técnico Edvaldo Dal Vecchio pela ajuda técnica imprescindível. 


\title{
SÍNTESE DE ZEÓLITAS E WOLASTONITA À PARTIR DA CINZA DA CASCA DO ARROZ
}

\section{Alberto de Andrade Fernandes}

\begin{abstract}
RESUMO
A cinza da casca do arroz (CCA) é um resíduo rico em sílica amorfa. Um método simples e de baixo consumo energético para extração desta sílica foi pesquisado, obtendo-se um material com baixo teor de impurezas e alta reatividade, adequado para a síntese de zeólitas e wolastonita $\left(\mathrm{CaSiO}_{3}\right)$. As zeólitas sintéticas, que não possuem estruturas similares na natureza, são cada vez mais valorizadas no mercado devido a pureza e eficiência em aplicações específicas nas áreas de troca iônica, peneira molecular e catálise. A wolastonita com elevado grau de pureza tem várias aplicações na indústria e agricultura. $O$ mineral wolastonita pode ser formado de várias maneiras na natureza. Em geral é aceito que existem dois processos de formação; os quais envolvem o metamorfismo (calor e pressão) do calcário. Neste trabalho, foi desenvolvido um novo processo para a síntese das zeólitas e da wolastonita, ambas a partir da sílica coloidal da CCA; tendo como objetivo um processo de um menor custo energético, menor número de etapas e menor consumo de reagentes. Foram sintetizadas neste trabalho as zeólitas: $A$, usada em detergentes, e a ZSM-5, empregada na indústria petroquímica, devido a sua alta seletividade em reações catalíticas e grande estabilidade térmica e resistência aos ácidos. A primeira etapa na síntese da wolastonita foi estudada com o objetivo da formação do hidrossilicato de cálcio (CSH). Contudo, onze hidrossilicatos de cálcio diferentes ocorrem no sistema $\mathrm{Ca}(\mathrm{OH})_{2}-\mathrm{SiO}_{2}-\mathrm{H}_{2} \mathrm{O}$ que em uma segunda etapa passam por um tratamento térmico para dar formação a fase wolastonita.
\end{abstract}


ZEOLITE AND WOLASTONITE SYNTHESIS FROM RICE HULL ASH

\title{
Alberto de Andrade Fernandes
}

\begin{abstract}
Rice hull ash (RHA) is a industry scrap rich in amorphous silica. A simple and lowenergy cost method for the extraction of this silica was researched. A low level of impurity and high reactivity material was produced, which is appropriate for the synthesis of zeolites and wolastonite $\left(\mathrm{CaSiO}_{3}\right)$. The synthetic zeolites, has not similar structures in nature, and they have been more and more valued in the market due to their purity and efficiency in specific applications like ion exchange, molecular sieve and catalysis areas. High purity wolastonite has many applications in manufacturing and agriculture. The mineral wolastonite can be formed in nature in different ways; it is generally accepted two forming processes, both encompassing limestone metamorphism (heat and pressure). In this work, a new process for the synthesis of zeolites and wolastonite from RHA colloidal silica was developed. Moreover, the process is aimed at lower energy costs, fewer stages and fewer reactants consume. In this work, zeolite $A$ used in detergent and zeolite ZSM-5, employed in the petrochemical industry due to its high selectivity in catalytic reactions and its high thermo and acid stability, were synthesized. The first step of the wolastonite synthesis was studied, with the purpose of obtaining calcium hydrosilicate. Eleven different hydrosilicates occur in the system $\mathrm{Ca}(\mathrm{OH})_{2}$ $\mathrm{SiO}_{2}-\mathrm{H}_{2} \mathrm{O}$, in the second step, it was annealed to form the wolastonite phase.
\end{abstract}




\section{SUMÁRIO}

páginas

1. INTRODUÇÃO

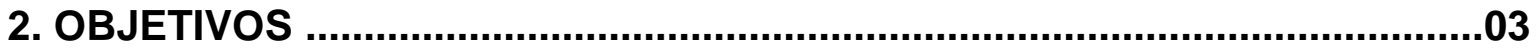

3. CONSIDERAÇÕES GERAIS SOBRE MATERIAIS E PROCESSOS .............04

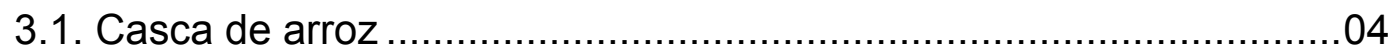

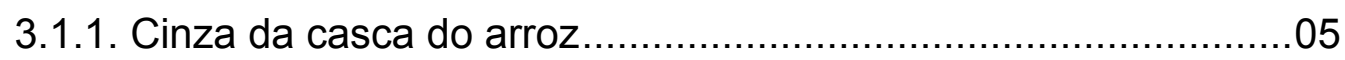

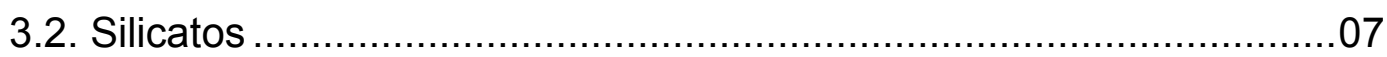

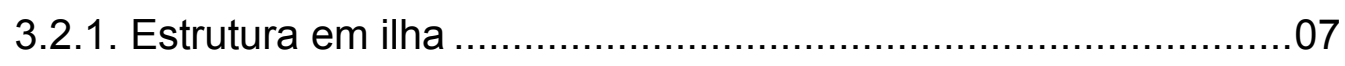

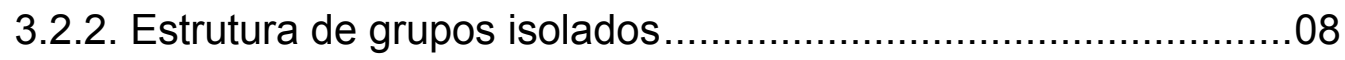

3.2.3. Estrutura em cadeia (metassilicatos) ………….......................08

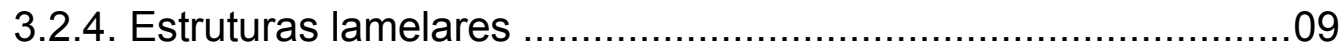

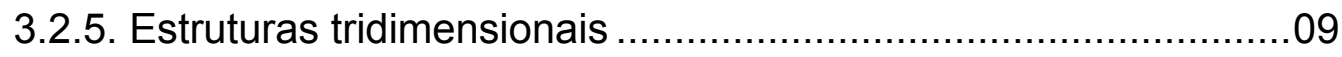

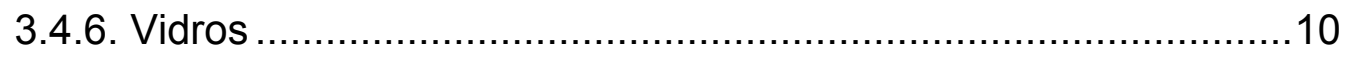

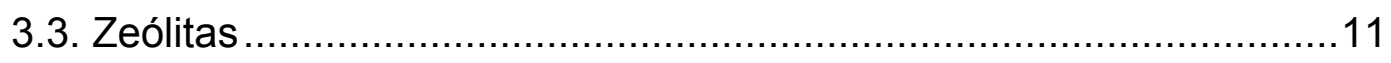

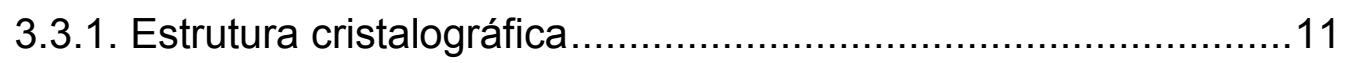

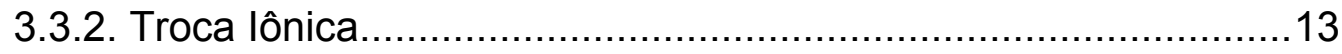

3.3.3. Peneira molecular ............................................................ 14

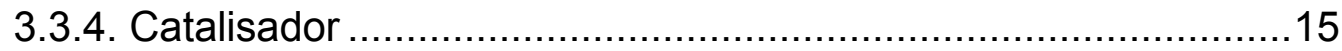

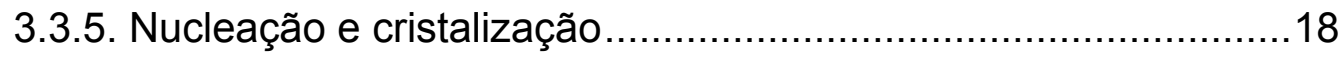

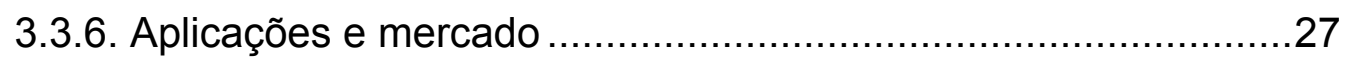

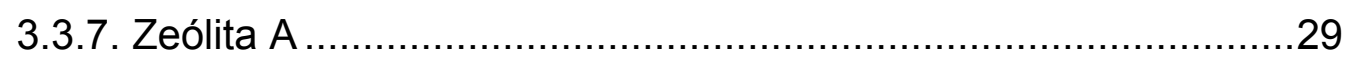

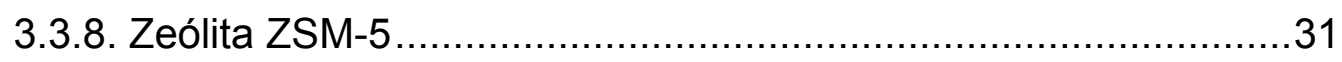

3.4. Wolastonita

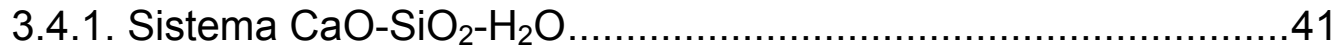

3.4.2. Síntese da wolastonita ............................................................ 44

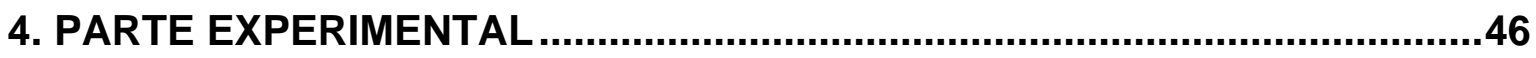

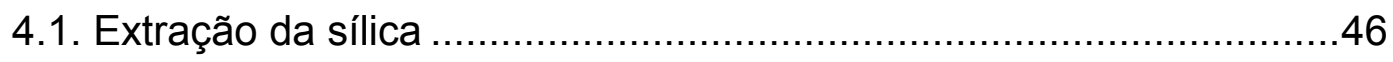

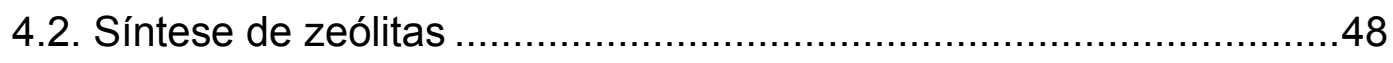

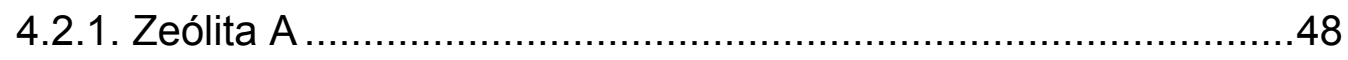


4.2.2. Zeólita ZSM-5. 51

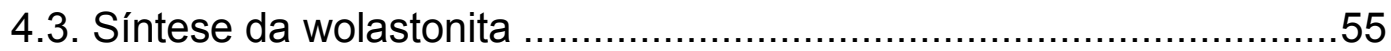

4.4. Métodos de caracterização .............................................58

5. RESULTADOS .60

5.1. Extração da sílica .........................................................60

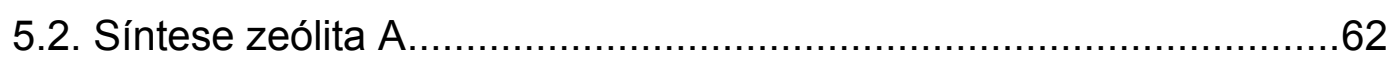

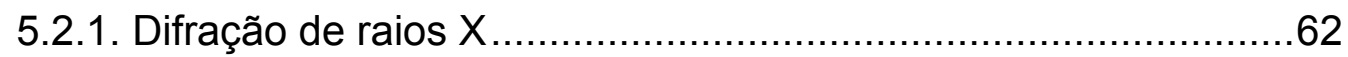

5.2.2. Medidas físicas e químicas ...........................................65

5.2.3. Microscopia eletrônica de varredura ...................................66

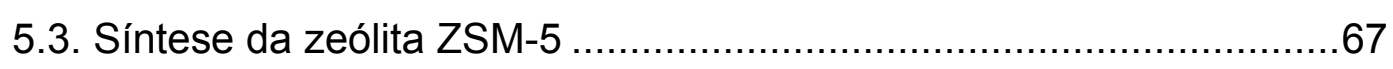

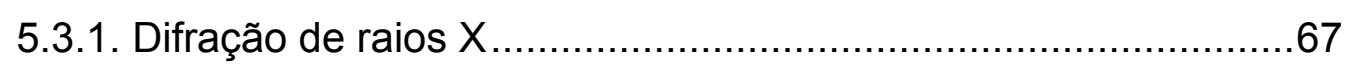

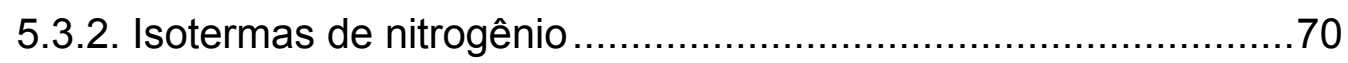

5.3.3. Microscopia eletrônica de varredura .................................. 71

5.4. Síntese da wolastonita .......................................................... 72

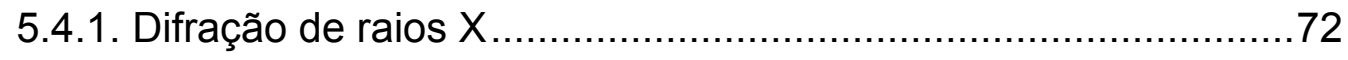

5.4.2. Análise química quantitativa............................................. 76

5.4.3. Microscopia eletrônica de varredura ....................................76

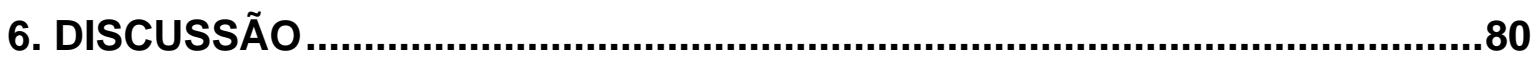

6.1. Extração da sílica da CCA................................................. 80

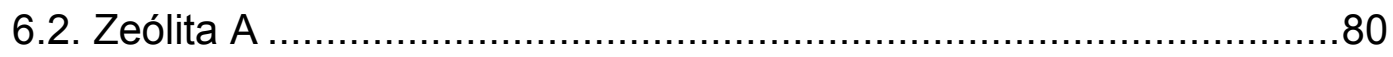

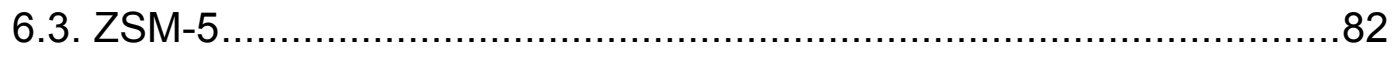

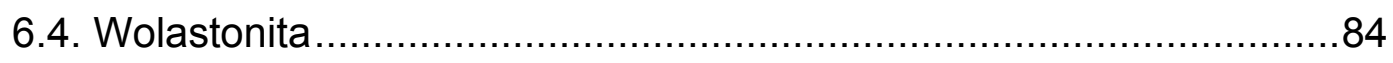

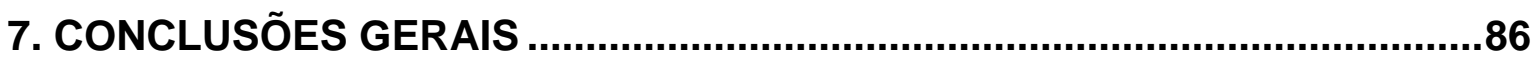

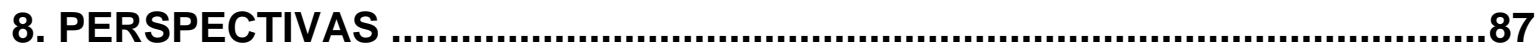

REFERÊNCIAS BIBLIOGRÁFICAS...........................................................88 


\section{LISTA DE TABELAS}

páginas

Tabela 1- Relação entre a propriedade da zeólita e o efeito catalítico. 15

Tabela 2 - Relação e vantagens das principais zeólitas usadas atualmente como catalisador 17

Tabela 3 - Fases formadas no sistema $\mathrm{CaO}-\mathrm{SiO}_{2}-\mathrm{H}_{2} \mathrm{O}$ até $200^{\circ} \mathrm{C} \ldots \ldots \ldots \ldots \ldots \ldots . . . \ldots 3$

Tabela 4 - Condições de síntese das amostras de zeólita A...............................51

Tabela 5 - Relação das amostras sintetizadas com etanol ..............................54

Tabela 6 - Etapas no processo de síntese das amostras W1 até W6 ................57

Tabela 7 - Etapas no processo de síntese das amostras W7 até W9 .................57

Tabela 8 - Peneiramento e etapa 6 na síntese das amostras W10 até W17 ......58

Tabela 9 - Resultados das soluções de silicato de sódio ................................61

$\underline{\text { Tabela } 10}$ - Análise química da amostra A3 ..........................................6

Tabela 11 - Análise química e física das amostras de zeólita ZSM-5 ................70

Tabela 12 - Informações em um padrão de DRX .......................................81 


\section{LISTA DE FIGURAS}

páginas

Figura 1 - Representação gráfica da composição quantitativa da CCA ................04

Figura 2 - Estrutura cristalina da wolastonita ........................................... 09

Figura 3 - Estrutura da sílica cristalina e amorfa ........................................11

Figura 4 - Unidades secundárias de construção ...........................................13

Figura 5 - Catálise por seleção de forma ................................................17

Figura 6 - Representação esquemática da formação do núcleo no gel reacional.21

Figura 7 - Relações de energia livre esquemática entre várias fases zeolíticas ...22

Figura 8 - Vista da estrutura da zeólita A através da direção [001] .....................30

Figura 9 - Diagrama de fase da mistura reacional do sistema $\mathrm{SiO}_{2}-\mathrm{Al}_{2} \mathrm{O}_{3}-\mathrm{Na}_{2} \mathrm{O}$..31

Figura 10 - Estrutura da ZSM-5 vista através da direção [010] ..........................32

Figura 11 - Anéis das zeólita ZSM-5 e ZSM-11 visto nas direções [100] e [010]..33

Figura 12 - Diferença na disposição dos canais entre a ZSM-5 e ZSM-11 ...........33

Figura 13 - A orientação do TPA nos canais da ZSM-5 ................................. 34

Figura 14 - A estrutura da wolastonita em cadeia ........................................... 37

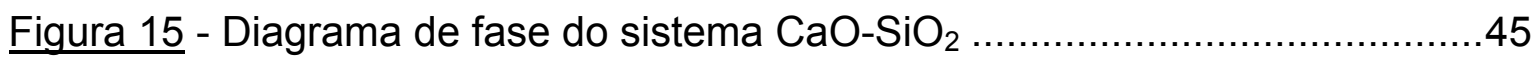

Figura 16 - Fluxograma da seqüência de extração da sílica na CCA ..................47

Figura 17 - Fluxograma da seqüência de síntese da zeólita $A$...........................50

Figura 18 - Fluxograma de síntese da zeólita ZSM-5 ................................52

Figura 19 - Fluxograma de síntese da wolastonita.........................................55

Figura 20 - Difratograma de raio $X$ da CCA queimada a $1100^{\circ} \mathrm{C} \ldots \ldots \ldots \ldots \ldots \ldots \ldots . . . . . . . . .60$

Figura 21 -Massa de sílica extraída, em valor absoluto e porcentagem, da CCA queimada a alta temperatura em função das diferentes relações de silício e sódio

Figura 22 -Gráfico de densidade entre o silicato de sódio (P.A.) e o silicato obtido da CCA

Figura 23 -Difratograma de raios $X$ da amostra A1, que mostra a nucleação da zeólita X.

Figura 24 -Difratograma de raios $X$ da amostra A2, que mostra a nucleação das fases $A$ e $X$.

Figura 25 - Difratograma de raios $X$ da amostra $A 3$, que mostra a zeólita $A$ .64

Figura 26 -Difratograma de raios $X$ da amostra A4 com cristalização da zeólita

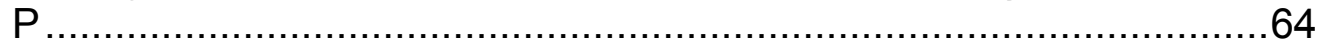

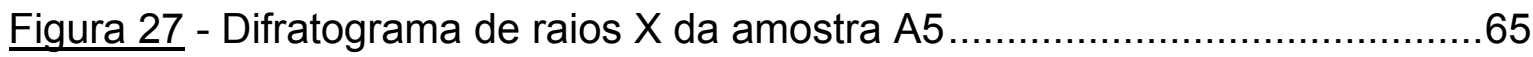


Figura 28 - Difratograma de raios $X$ da amostra A6.

Figura 29 -Representação fotográfica do MEV para a amostra A3 com um aumento de 500x.

Figura 30 -Representação fotográfica MEV para a amostra A3 com um aumento de $1600 x$.

Figura 31 - Difratograma de raios $X$ da amostra AZSM-5

Figura 32 - Difratograma de raios $X$ da amostra Zeo2 .68

Figura 33 - Difratograma de raios $X$ da amostra ET I.

Figura 34 - Difratograma de raios $X$ da amostra ET II. 69

Figura 35 - Difratograma de raios $X$ da amostra ET $V$ .70

Figura 36 -Representação fotográfica do MEV da amostra DZSM-5 com aumento de 4000X.

Figura 37 -Representação fotográfica do MEV da amostra Zeo2 com aumento de 2000X

Figura 38 -Representação fotográfica do MEV da amostra SILZ2 com aumento de 4000X.

Figura 39 - Difratogramas de raios $X$ das amostras W1, W2 e W3 ......................73

Figura 40 - Difratogramas de raios $X$ das amostras $W 4$, W5 e W6 .......................73

Figura 41 - Difratogramas de raios $X$ das amostras W8 e W7 ……....................74

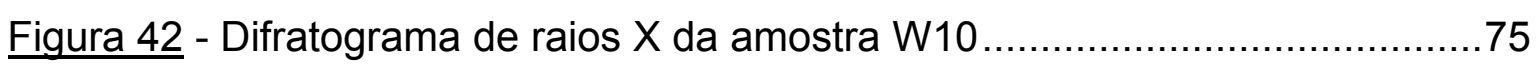

Figura 43 - Difratograma de raios $X$ da amostra W14 …...............................

Figura 44 -Gráfico representativo dos resultados obtidos de análise química quantitativa das amostras W4 até W17 em relação a proporção em

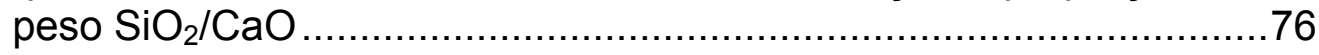

Figura 45 - Representação fotográfica de MEV da amostra W5 com aumento de $1600 \mathrm{X}$

Figura 46 - Representação fotográfica de MEV da amostra W5 com aumento de $3200 X$

Figura 47 - Representação fotográfica da amostra W10 com aumento de 46X....78

Figura 48 - Representação fotográfica da amostra W10 com aumento de 500X..78

Figura 49 - Representação fotográfica da amostra W13 com aumento de 40x ....79

Figura 50 - Representação fotográfica da amostra W14 com aumento de 500x ..79

Figura 51 - Planos de clivagem do cristal de ZSM-5 .83 


\section{LISTA DE ABREVIATURAS}

BET - Brunauer, Emmett \& Teller.

CCA - Cinza da casca do arroz.

$\mathrm{CSH}$ - Silicato de cálcio hidratado.

DRX - Difração de raios $X$.

ICP - Inductively coupled plasma.

MEV - Microscopia eletrônica de varredura.

OES - Optical emission spectrometry.

Sbus - Secondary building unit.

TPA - Cátion de tetrapropilamônio.

ZSM - Zeolite socony mobil. 


\section{INTRODUÇÃO}

A pesquisa visando a transformação e o aproveitamento de resíduos industriais e agrícolas em produtos de interesse comercial exerce um papel cada vez mais relevante, no mundo que tem no agronegócio uma fonte de renda cada vez maior. Em vista do crescente aprimoramento da indústria de cerâmicas, a necessidade de avanços tecnológicos para melhorar a relação custo/benefício dos materiais torna legítima a diversificação dos fornecimentos de matériasprimas buscando integrar diferentes cadeias produtivas. Portanto, a criação de produtos a partir destes resíduos que, atualmente, são importados pelo Brasil, agrega valor e cria riqueza e, por isso, se torna importante para o país.

As zeólitas e wolastonita sintéticas com elevado grau de pureza têm muitas aplicações na indústria e agricultura e, atualmente, são importadas pelo Brasil. Reduzir a geração de resíduos nos processos industriais e agrícolas, melhor aproveitá-los e criar rotas com menor custo e produtos mais baratos, é o objetivo de toda economia que busca a modernização.

As cinzas da casca do arroz (CCA), um rejeito da indústria do arroz, pode-se tornar verdadeiramente útil na fabricação de diferentes materiais, já que são produzidas em grandes quantidades no país. A alta concentração de sílica, $\mathrm{SiO}_{2}$, nas CCA e sua extração com baixo custo e elevado teor de pureza, torna-se útil para a indústria dos silicatos.

A extração de sílica das CCA por lixiviação alcalina é um processo de baixo custo energético e de extrema eficiência, obtendo uma sílica de alta pureza, com estrutura amorfa de grande reatividade, o que a torna extremamente interessante para a produção de zeólitas e wolastonita. Um subproduto deste processo é um carvão puro com granulometria extremamente fina, com um bom valor comercial e de interessantes aplicações.

O Brasil é um dos maiores produtores de grãos, sendo o primeiro da América Latina na produção de arroz. A produção anual de arroz em casca na safra 2000/2001, segundo o IBGE, foi de 11 milhões de toneladas. Em média, do total do arroz colhido, $23 \%$ corresponde à casca e $4 \%$ corresponde a cinza. Assim, tem-se cerca de 440.000 toneladas de resíduo gerado como cinza. Visto que $75 \%$ da cinza é sílica amorfa, tem-se a disposição 330.000 toneladas deste material. Um processamento de $15 \%$ deste material obteríamos 45.500 toneladas 
de sílica, que comercializada a um preço de $R \$ 600,00 / t$, possibilitará um faturamento anual, somente em relação a extração, de aproximadamente $R$ \$ 27.300.00,00.

Os processos comerciais atuais para produzir o vidro sólido (Stephens et al., 2002; Reiber et al., 1998.), necessitam de soluções de silicatos alcalinos obtidos por fusão de areia (quartzo) e soda cáustica em fornos à temperaturas de 1300 a $1500^{\circ} \mathrm{C}$. A solução de silicato de sódio é obtida dissolvendo o vidro com vapor e água quente. Esta é a base de todos os processos comerciais atuais para a produção de silicatos solúveis. O processo requer muita energia, tem alto custo, e os silicatos, geralmente, contém contaminantes da ordem de 500 a 10.000 ppm. 


\section{OBJETIVOS}

Este trabalho tem como objetivo geral desenvolver um processo de síntese, e economicamente, viável para a produção de zeólitas e wolastonita de alta pureza, a partir de casca do arroz. Esse resíduo agrícola, atualmente é descartado, gerando um passivo ambiental, que pode ser bastante promissor para a produção de materiais de alto valor agregado. O Brasil não possui minérios com valor econômico destes produtos e nem processa seus similares sintéticos. Portanto, o presente estudo tem a finalidade de reduzir o passivo ambiental com a diminuição de resíduos de processos industriais e agrícolas, além de permitir dominar cientifica e tecnologicamente processos de síntese com menor custo e conseqüentemente produtos mais baratos.

Como objetivos específicos temos:

- Estudo do processo de lixiviação da CCA com NaOH como fonte de sílica coloidal de obtenção fácil e reatividade alta.

- Desenvolvimento de processo alternativo e inovador na síntese das zeólitas: A e ZSM-5, usando a CCA como matéria-prima.

- Desenvolvimento de processo alternativo e inovador na síntese de wolastonita sintética, usando a CCA como matéria prima. 


\section{CONSIDERAÇÕES GERAIS SOBRE MATERIAIS E PROCESSOS}

\subsection{Casca de arroz}

O arroz após a colheita é armazenado em silos e submetido a um processo de secagem que reduz a umidade para cerca de $12 \%$. Durante o beneficiamento os grãos são separados de impurezas e descascados, dando origem as seguintes frações: arroz inteiro, grãos quebrados, farelo, palha, haste e casca. (Gomes et al., 2000).

O grão quebrado é adicionado ao grão inteiro em diferentes proporções. Com o farelo se produz óleo comestível, concentrado protéico, fibras para nutrição e amido. A palha é usada para alimento do gado e a haste na indústria de papel.

Esforços visando a utilização direta da casca têm encontrado sucesso limitado por causa de seu caráter altamente abrasivo, pobre valor nutritivo, alta resistência a degradação, baixa densidade e alto teor de cinzas (Souza et al., 2000).

Os principais constituintes orgânicos da casca são celulose e hemicelulose ( $48 \%$ ), lignina ( $23 \%$ ) e o restante sendo outros compostos orgânicos como óleo e proteínas. A concentração de cinzas totais na casca seca pode ser até de $27 \%$ em peso de acordo com a Figura 1.

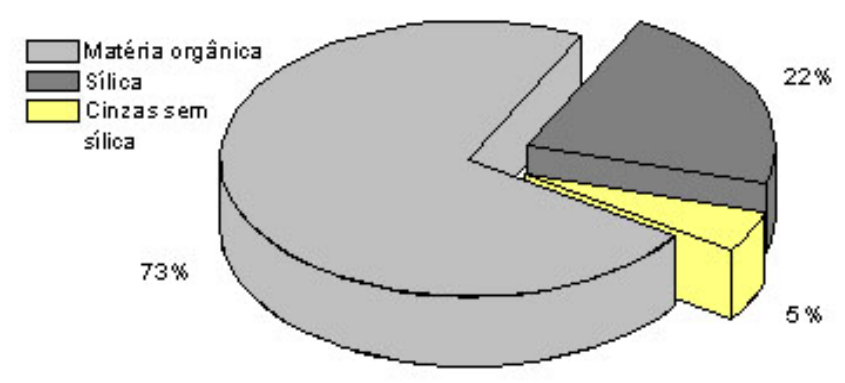

Figura 1 - Representação gráfica da composição quantitativa da CCA.

A cinza, sem a sílica, consiste de $\mathrm{K}_{2} \mathrm{O}, \mathrm{CaO}, \mathrm{MgO}, \mathrm{Al}_{2} \mathrm{O}_{3}, \mathrm{MnO}, \mathrm{P}_{2} \mathrm{O}_{5}$ em proporções que dependem da natureza do solo e variedade da planta. São classificados como impurezas porque eles mudam as propriedades da sílica, produzida da casca. 
A sílica está distribuída principalmente na camada exterior da casca. Na planta a palha contem também alta concentração de sílica, com cerca de 13\%. A relação em massa palha/casca é de cerca de 3,6 (Persegil et al., 2002).

A sílica amorfa é a forma predominante no arroz, a sílica cristalina é encontrada em várias plantas.

\subsubsection{Cinza da casca do arroz}

Devido à casca do arroz ser uma fonte de energia renovável, com um razoável teor energético de 12-18 MJ/Kg (Mansaray et al.,1998) e ter um alto custo de transporte em face ao baixo empacotamento, esta acaba sendo usada como combustível no próprio processo de beneficiamento do arroz. A queima, dependendo das condições, produz um resíduo negro que contém em média cerca de $15 \%$ de carbono e o restante de sílica, este resíduo conhecido como cinza da casca de arroz (CCA) apresenta como principais impurezas $\mathrm{K}, \mathrm{Ca}, \mathrm{Mg} \mathrm{e}$ Al e é danoso para o meio ambiente e à saúde humana (Souza et al.,2000).

Vários processos têm sido propostos para o aproveitamento da CCA, objetivando produtos de baixo valor agregado ou não. Devido ao seu elevado teor de sílica foi estudada a utilização na fabricação de vidros, isolantes térmicos, tijolos prensados, materiais refratários, cimento Portland, agregado em argamassas e refratários silicosos ácidos (Della et al.,2001). Com aplicação também na indústria farmacêutica, cosméticos, detergentes, ligantes e agentes adesivos (Kalapathy et al.,2000). Vários pesquisadores têm considerado à sílica obtida da CCA como matéria-prima para a obtenção de silício com grau solar (SiGS), carbeto de silício whiskers (SiC) (Martinelli \& Bressiani.,1990), cerâmicas de nitreto de silício $\left(\mathrm{Si}_{3} \mathrm{~N}_{4}\right)$ (Martinelli \& Bressiani.,1992), mulita e silicato de sódio e potássio.

Diferentes métodos de obtenção da sílica afetam sua estrutura e morfologia, que influenciam na sua reatividade. A sílica amorfa é em geral extremamente ativa para a síntese da zeólita (Hamdan et al.,1997).

Existem dois métodos para a obtenção da sílica a partir da CCA, calcinação com atmosfera controlada (entre $400-700^{\circ} \mathrm{C}$ ) e lixiviação em meio alcalino.

O primeiro consome muita energia e produz uma sílica cristalina e pouco reativa com uma área de superfície específica de cerca de $10 \mathrm{~m}^{2} / \mathrm{g}$ e baixo 
valor econômico. Existem estudos recentes em que a CCA é previamente tratada em lixiviação ácida para remover os óxidos de metais alcalinos e alcalinos terrosos. Estes funcionam como fundentes, com parte da sílica, produzindo vidros soda-cal e diminuindo a área superficial específica (Persegil et al.,2002).

No segundo método a sílica amorfa pode ser extraída por lixiviação em baixa temperatura, cerca de $90^{\circ} \mathrm{C}$. A solubilidade da sílica amorfa é muito baixa em $\mathrm{pH}<10$ e aumenta bruscamente com pH > 10 (Kalapathy et al.,2000). Este comportamento único permite a extração de sílica da CCA, em uma forma pura, por solubilização sob condições alcalinas, e uma subseqüente precipitação em baixo pH (Brinker et al.,1990).

Na produção da solução de silicato alcalino, como o silicato de sódio, usando como matéria prima uma cinza de origem orgânica com sílica amorfa, a quantidade de carbono pode chegar a $30 \%$ da cinza na lixiviação alcalina. O carbono é um material inerte durante a reação e o excesso não é danoso (Stephens et al.,2002). A principal reação química do processo de extração cáustica é a seguinte:

$$
2 \mathrm{NaOH}+\mathrm{nSiO}_{2}+\mathrm{H}_{2} \mathrm{O} \rightarrow \mathrm{Na}_{2} \mathrm{O}: \mathrm{nSiO}_{2}+2 \mathrm{H}_{2} \mathrm{O}
$$

onde $\mathrm{n}$ pode variar de 1,6 a 3,8 .

$\mathrm{Na}$ precipitação da sílica com ácido obtém-se a sílica gel ou sol dependendo da concentração.

Entre a classificação de solução homogênea e mistura heterogênea existe a dispersão coloidal ou simplesmente, colóide. Neste, as partículas dispersas são pequenas para serem visualizadas, não se sedimentam e não podem ser separadas por filtração comum. A partícula coloidal típica tem a sua dimensão entre $10^{-6} \mathrm{~m}$ e $10^{-9} \mathrm{~m}$. Os tipos diferentes de colóides incluem o sol (dispersão de partículas sólidas em um líquido), a emulsão (dispersão de gotas de um líquido em outro líquido), a fumaça (partículas sólidas dispersas em um gás) e o nevoeiro (gotas de um líquido em um gás), este últimos são conhecidos também como aerossóis.

Um outro tipo de colóide é o gel (ou alcogel), no qual ambas as fases dispersa e dispersante se distribuem, uniformemente, pelo sistema formando uma rede tridimensional. No gel, a fase dispersa forma filamentos finos ou retículo denso que mantém a fase dispersante em uma estrutura semi-rígida. A estrutura 
tri-dimensional da fase dispersa em alguns géis pode ser temporariamente rompida pela aplicação de força de agitação. Este, em seguida, se reverte a sol o qual não é mais semi-rígido. Mantido sem perturbação, o sistema reconstitui o gel, este fenômeno é conhecido como tixotropia.

O aerogel é o que resta do gel quando a parte líquida é removida sem danos na parte sólida (freqüentemente alcançado por extração supercrítica). Se feito corretamente, o aerogel preserva a forma original do gel com $50 \%$ do volume, no mínimo. O xerogel é o que resta quando a parte líquida do gel é removida por evaporação. O xerogel pode reter sua forma original mas geralmente há rupturas, aonde a contração durante a secagem é geralmente extrema $(\sim 90 \%)$.

\subsection{Silicatos}

$\mathrm{Na}$ estrutura dos silicatos a unidade fundamental é o tetraedro que consiste de pequenos cátions, como o $\mathrm{Si}^{4+}$, em uma coordenação tetraédrica com quatro oxigênios (primeira regra de Pauling)(Kingery et al.,1976). O raio da ligação Si-O é 0,29Á com uma força de ligação igual a 1 (valência 4/coordenação 4), o baixo número de coordenação faz a estrutura de empacotamento denso impossível para o $\mathrm{SiO}_{2}$, e em geral os silicatos tem estrutura mais aberta. $\mathrm{O}$ íon $\mathrm{Al}^{3+}$ geralmente se coordena em tetraedros, assim como, em octaedros, com o oxigênio nos silicatos. Isto tem um efeito profundo na estrutura dos aluminosilicatos e sua composição. Outros íons que se coordenam em tetraedros são o $\mathrm{P}^{5+}, \mathrm{Ga}^{2+}$ e o $\mathrm{Ge}^{4+}$. A complexidade da estrutura dos silicatos ocorre devido às várias opções em que os grupos de tetraedros podem se conectar, dividindo o oxigênio comum, e formando estruturas complexas (Kingery et al.,1976). Considerável variação na composição química resulta da substituição de cátions nas posições tetraédricas e octaédricas como permitido pela regra de eletrovalência de Pauling.

Existem seis tipos principais de estruturas de silicatos, que são:

\subsubsection{Estruturas em Ilha.}

O tetraedro $\mathrm{SiO}_{4}{ }^{4-}$ existe com diferentes íons nos silicatos, são conhecidos como ortossilicatos ou mesossilicatos. Os quatro átomos de 
oxigênio não estão ligados a nenhum outro átomo de silício. Eles apresentam a fórmula $\mathrm{M}^{\mathrm{IV}} \mathrm{SiO}_{4}$ como a zirconita, $\mathrm{ZrSiO}_{4}$, ou dois cátions diferentes como o ortossilicato de cálcio e sódio, $\mathrm{Na}_{2} \mathrm{CaSiO}_{4}$.

\subsubsection{Estruturas de grupos isolados.}

Duas estruturas $\mathrm{SiO}_{4}{ }^{4-}$ podem se conectar formando grupos com a divisão do oxigênio da quina que são os pirossilicatos ou dissilicatos, $\left(\mathrm{SiO}_{7}{ }^{6-}\right)$. Estas estruturas são raras e como exemplo tem-se a thortveitita, $\mathrm{Sc}_{2} \mathrm{Si}_{2} \mathrm{O}_{7}$.

\subsubsection{Estruturas em cadeia (metassilicatos).}

Se os tetraedros são conectados por duas quinas, isto é, dois oxigênios divididos, então a estabilidade da estrutura é consideravelmente reduzida devido à repulsão coulombiana dos cátions. Isto aproxima o centro dos cátions em um fator de 0,58. Esta é a base da terceira regra de Pauling.

A estrutura em cadeia compreende três grandes grupos:

Os de cadeia simples, $\left(\mathrm{SiO}_{3}\right)_{\mathrm{n}}{ }^{2 \mathrm{n}-}$, chamados de piroxênios, que apresentam na estrutura os tetraedros divididos em duas quinas, isto é, dois oxigênios. Dependendo da disposição dos tetraedros no espaço, o tamanho das unidades repetitivas ao longo da cadeia pode variar, alterando a estrutura do silicato como a diopsita, $\mathrm{MgCa}\left(\mathrm{SiO}_{3}\right)_{2}$. Na wolastonita de cadeia simples a unidade repetitiva é constituída por três tetraedros (Figura 2).

Os de cadeia dupla, $\left(\mathrm{Si}_{4} \mathrm{O}_{11}\right)_{n}{ }^{6 n-}$, chamados de anfibólios. Nesse caso, tem-se na verdade duas cadeias simples conectadas. Um exemplo é a tremolita, $(\mathrm{OH})_{2} \mathrm{Ca}_{2} \mathrm{Mg}_{5}\left(\mathrm{Si}_{4} \mathrm{O}_{11}\right)_{2}$, em que a substituição isomórfica é comum, e como outro exemplo tem-se os asbestos.

As ligações Si-O nas cadeias são fortes e direcionais. Cadeias adjacentes são mantidas unidas pelos íons metálicos presentes. Por isso, os piroxênios e os anfibólios podem ser facilmente clivados na direção paralela às cadeias, formando assim fibras.

Existem também os de cadeia cíclica, $\left(\mathrm{SiO}_{3}\right)_{\mathrm{n}}{ }^{2 \mathrm{n}-}$, como os tetraedros que dividem as arestas formando anéis contendo três, quatro, seis e oito unidades tetraédricas, sendo mais comum as que contêm de três a seis como na benitoíta, $\mathrm{BaTi}\left[\mathrm{Si}_{3} \mathrm{O}_{9}\right]$, que contém o íon cíclico $\mathrm{Si}_{3} \mathrm{O}_{9}{ }^{6-}$. 


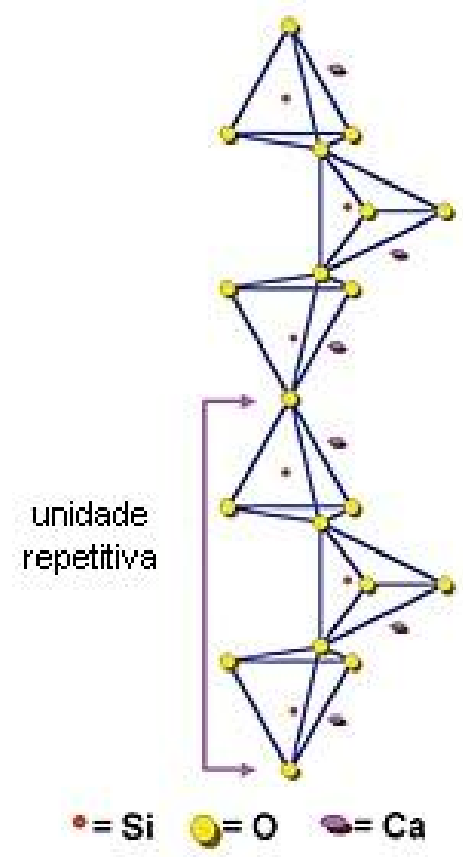

Figura 2- Estrutura cristalina da wolastonita(Ciullo \& Robinson.,2002).

\subsubsection{Estruturas lamelares.}

Conectando três quinas de cada tetraedro com o tetraedro vizinho é formada uma rede planar bi-dimensional que forma infinitos anions de composição $\left(\mathrm{Si}_{2} \mathrm{O}_{5}\right)_{\infty}{ }^{2-}$.

Se está estrutura bi-dimensional é conectada a outro plano $\mathrm{AlO}(\mathrm{OH})_{2}$, as camadas que estão juntas formam a composição $\mathrm{Al}_{2}\left(\mathrm{Si}_{2} \mathrm{O}_{5}\right)(\mathrm{OH})_{4}$, conhecida como caolinita, a argila mais comum. $\mathrm{Na}$ interposição de uma folha de octaedros, $\mathrm{Mg}(\mathrm{OH})_{2}$, entre duas folhas $\mathrm{Si}_{2} \mathrm{O}_{5}$, forma-se o talco.

\subsubsection{Estruturas tridimensionais}

Uma armação estrutural que cresce nas três dimensões é o resultado quando todos os oxigênios no tetraedro são divididos com outros tetraedros de silício ou alumínio. A substituição de um quarto do $\mathrm{Si}^{4+}$ por $\mathrm{Al}^{3+}$, leva a formação do íon tridimensional $\mathrm{AlSi}_{3} \mathrm{O}_{8}{ }^{-}$. Os cátions são geralmente íons metálicos grandes, tais como $\mathrm{K}^{+}, \mathrm{Na}^{+}, \mathrm{Ca}^{2+}$ ou $\mathrm{Ba}^{2+}$. Íons menores como $\mathrm{Fe}^{3+}$, $\mathrm{Cr}^{3+} \mathrm{e} \mathrm{Mn}^{2+}$, que são comuns nos silicatos em cadeia e lamelares, não ocorrem nos silicatos tridimensionais, porque os interstícios no retículo cristalino são muito grandes. As estruturas do tipo $\mathrm{M}^{\prime}\left[\mathrm{AlSi}_{3} \mathrm{O}_{8}\right]$ e $\mathrm{M}^{\prime \prime}\left[\mathrm{Al}_{2} \mathrm{Si}_{2} \mathrm{O}_{8}\right]$ são responsáveis pelos grupos de minerais: feldspatos, ultramares e zeólitas. 
Na estrutura da sílica existem 17 variações cristalinas polimorficas, correspondendo as diferentes formas de combinação dos tetraedros que dividem as quatro quinas. As estruturas básicas são o quartzo, tridimita e cristobalita.

Os feldspatos são caracterizados por uma estrutura em que o $\mathrm{Al}^{3+}$ substitui alguns $\mathrm{Si}^{4+}$ formando uma rede de carga negativa que é balanceada por grandes íons em posições intersticiais como na albita, $\mathrm{NaAISi}_{3} \mathrm{O}_{8}$. A estrutura cristalina é similar a cristobalita com os cátions alcalinos e alcalinos terrosos ocupando os interstícios.

Os feldspatos são os minerais formadores das rochas mais importantes e constituem dois terços das rochas ígneas.

Os ultramares constituem um grupo de compostos que não contém

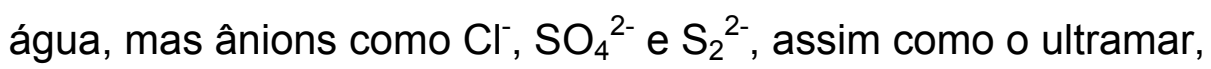
$\mathrm{Na}_{8}\left[\left(\mathrm{AlSiO}_{4}\right)_{6}\right] \mathrm{S}_{2}$, e a sodalita, $\mathrm{Na}_{8}\left[\left(\mathrm{AlSiO}_{4}\right)_{6}\right] \mathrm{Cl}_{2}$.

As zeólitas têm uma estrutura muito mais aberta que os feldspatos. O esqueleto com carga negativa contém canais que será detalhado no próximo item.

\subsubsection{Vidros}

Os vidros sólidos, no qual os silicatos formam o grupo tecnologicamente mais importante, usualmente tem uma estrutura mais complexa do que os líquidos que são derivados.

De acordo com o modelo de rede randômica, os vidros são vistos como redes tridimensionais com deficiência de simetria e periodicidade, no qual nenhuma unidade da estrutura é repetida a intervalos regulares. No caso de vidros de óxidos esta rede é composta por poliedros de oxigênio.

Adotando a hipótese de que o vidro deva ter uma quantidade de energia similar ao cristal correspondente, foi considerada a condição para a construção de uma rede randômica, como mostrado na Figura 3, e sugerido quatro regras para a formação de um vidro feito de óxidos:

- Cada oxigênio não pode estar conectado a mais que dois cátions.

- O número de coordenação do íon oxigênio deve ser pequeno, entre 4 ou menos.

- Os poliedros de oxigênio dividem quinas, não arestas ou faces. 
- No mínimo três quinas de cada poliedro devem ser divididas.

Os silicatos alcalinos formam vidros facilmente, e é o íon alcalino, supõe-se, que ocupa posições randômicas distribuídas através da estrutura, localizados de forma que provêem a neutralidade das cargas.

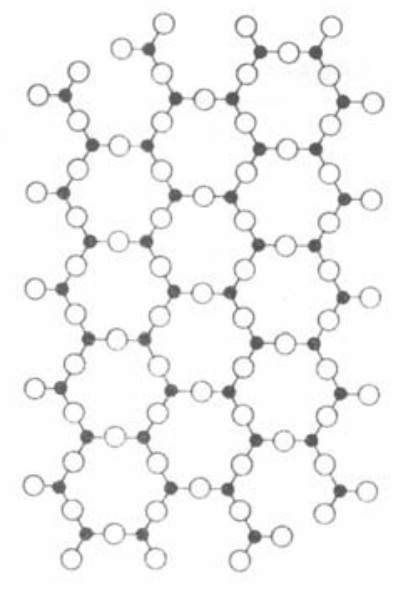

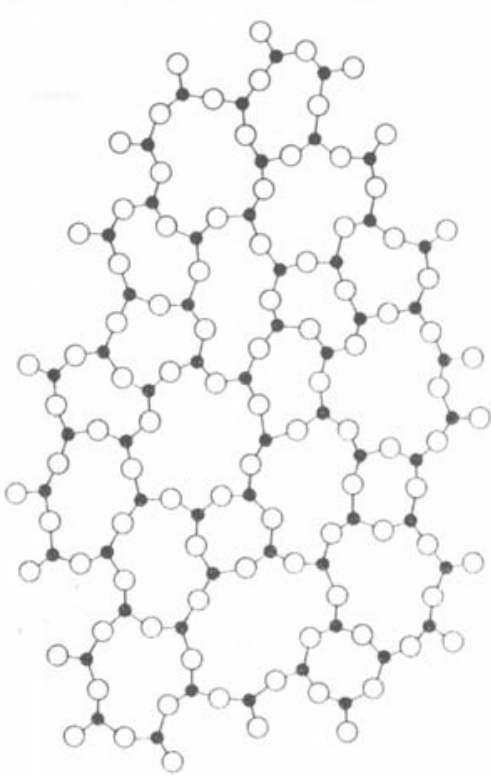

(b)

Figura 3 - Estrutura da sílica (a) cristalina e (b) amorfa. Círculos pretos são átomos de silício e círculos brancos átomos de oxigênio (Kingery et al.,1976).

$\mathrm{O}$ caráter randômico do vidro $\mathrm{SiO}_{2}$ resulta essencialmente da variação da distância Si-Si (o ângulo das ligações Si-O-Si). Através dos diferentes ângulos que ligam os tetraedros, a estrutura da sílica fundida é completamente randômica.

\subsection{Zeólitas}

\subsubsection{Estrutura cristalográfica.}

As zeólitas foram descritas pela primeira vez, como um grupo mineral, pelo mineralogista sueco Barão Axel Cronstedt em 1756. Elas são uma classe de aluminossilicatos hidratados cristalinos, constituída por metais alcalinos ou alcalinos terrosos, baseada em uma estrutura aniônica rígida, com canais e cavidades bem definidos. Estas cavidades contêm cátions metálicos permutáveis e podem segurar moléculas hospedeiras. Este tipo de estrutura microporosa faz com que as zeólitas apresentem uma enorme superfície interna em relação a externa. A estrutura da zeólita permite a transferência de matéria entre os 
espaços intracristalinos, no entanto essa transferência é limitada pelo diâmetro dos poros das zeólitas (Rabo., 1976).

A formula geral da composição da zeólita é:

$\mathrm{M}_{x / \mathrm{n}}\left[\left(\mathrm{AlO}_{2}\right)_{x}\left(\mathrm{SiO}_{2}\right)_{\mathrm{y}}\right] \cdot \mathrm{mH}_{2} \mathrm{O}$

Onde o cátion $M$ de valência $n$ neutraliza as cargas negativas na estrutura do aluminossilicato.

A estrutura é construída pela ligação dos tetraedros $\left[\mathrm{SiO}_{4}\right]^{4-} \mathrm{e}$ $\left[\mathrm{AlO}_{4}\right]^{5-}$ em que cada oxigênio do tetraedro é dividido com o próximo tetraedro seja este de Al ou Si (Dyer., 1988). Uma forma de classificar a estrutura das zeólitas seria relacionar a simetria de sua célula unitária. Isto poderia ser incômodo, e é muito simplista, pela observação que a estrutura das zeólitas muitas vezes tem idêntica (ou muito similar) as sub-unidades estruturais repetitivas que são menos complexas que sua célula unitária.

Estas unidades são chamadas de "unidade secundaria de construção" (sbus) e é a mais simples e útil classificação, que descreve todas as estruturas conhecidas de zeólitas em 18 sbus como mostrado na Figura 4. Esta representação é somente do esqueleto do aluminosilicato e exclui cátions adsorvidos e água. As quinas nas representações são átomos de oxigênio.

Com base na estrutura cristalina, as zeólitas podem ser divididas em dois tipos gerais: Um tipo inclui zeólitas tendo uma relação molar $\mathrm{SiO}_{2} / \mathrm{Al}_{2} \mathrm{O}_{3}$ menor que 12, que são convencionalmente preparadas sem modeladores orgânicos e muitas delas contém a sodalita na subestrutura (Miller.,2001). Estas possuem a estrutura mais fechada e com menor abertura dos canais. Os tipos com esta relação maior que 12 tem estrutura mais aberta e formam uma rede de canais. São geralmente preparadas com modeladores orgânicos. 


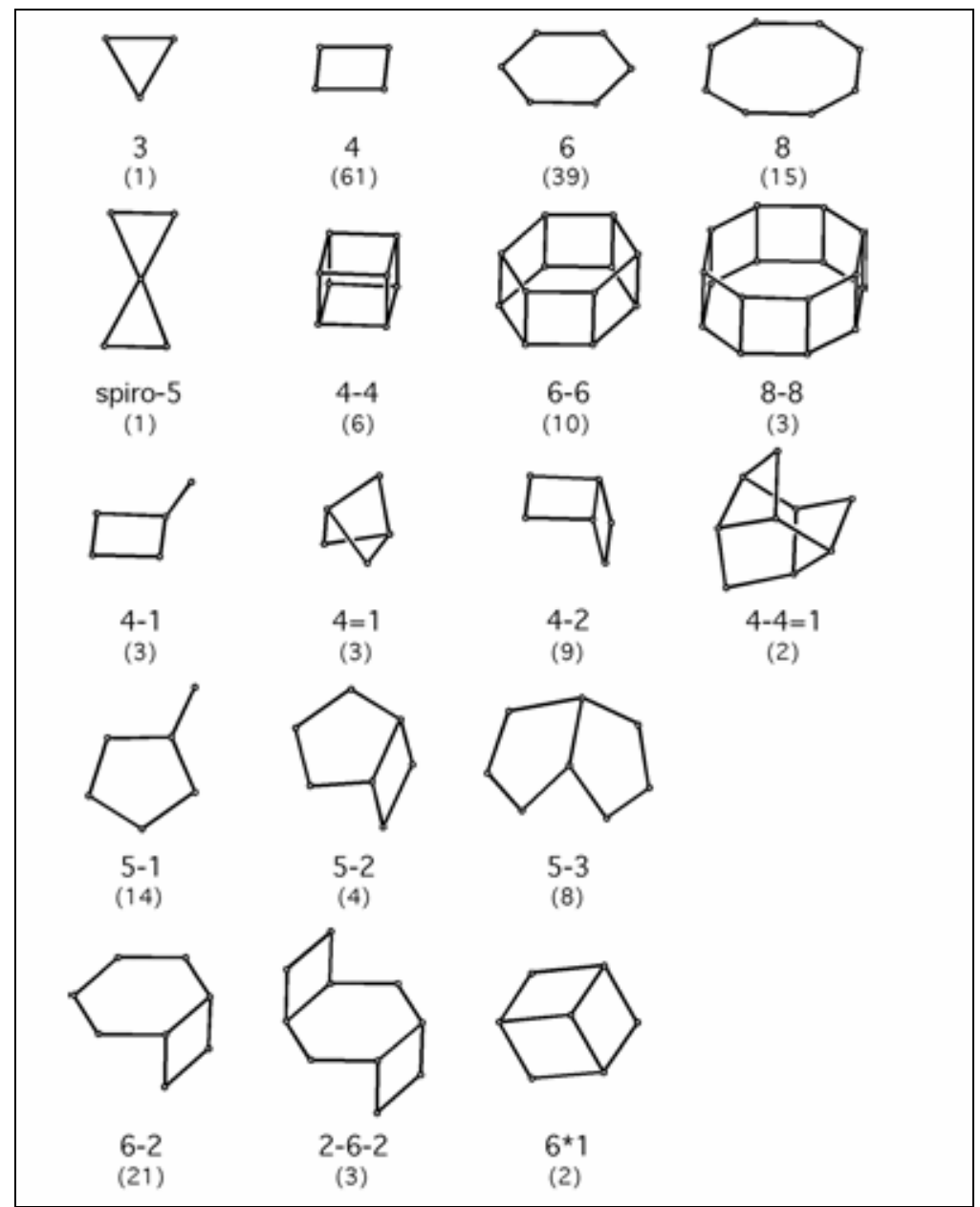

Figura 4 - Unidades secundárias de construção, número em parêntese se refere a freqüência de ocorrência(Baerlocher et al., 2001).

\subsubsection{Troca lônica.}

A propriedade de troca iônica da zeólita é uma função da relação $\mathrm{Si} / \mathrm{Al}$, quanto menor a relação, maior a disponibilidade de cátions para troca. Também tem forte influência o diâmetro dos poros e o tamanho do cátion a ser trocado. A capacidade é expressa em número de cátions por unidade de massa ou volume disponível para troca (Luz et al.,1995).

A localização e grau de incorporação das moléculas de água dependem da estrutura molecular, isto é, tamanho e forma das cavidades e canais, e também do número e natureza dos cátions presentes. Zeólitas com aberturas pequenas de poros não trocam cátions maiores que as mesmas. $\mathrm{A}$ troca de cátions também é dificultada na medida que aumenta o grau de hidratação dos cátions. A velocidade de troca é função da energia de interação entre o solvente e o cátion, por exemplo, em solução aquosa a troca do cálcio é 
muito mais rápida em relação à do magnésio à temperatura de $25^{\circ} \mathrm{C}$ na zeólita A de sódio.

De uma maneira geral a troca de cátions nas zeólitas pode ser influenciada pelas seguintes variáveis:

- Natureza, tamanho e carga do cátion.

- Estrutura cristalina da zeólita e relação Si/Al.

- Temperatura da solução.

- Concentração de cátions em solução.

- Ânion associado ao cátion em solução.

- pH da solução.

- Tratamento intermediário (ativação).

Conforme o aumento da relação Si/Al, a zeólita se torna mais hidrofóbica, quando esta relação tende a infinito esse material fica completamente sem água adsorvida (Kerr.,1989). As zeólitas essencialmente puras em sílicas, como algumas amostras de ZSM-5, tem na superfície de seus canais somente ligações do tipo Si-O-Si. A superfície de outras formas de $\mathrm{SiO}_{2}$ (como por exemplo: sílica gel e quartzo) consiste de grupos terminais $\mathrm{Si}-\mathrm{OH}$ que torna a superfície hidrofílica.

\subsubsection{Peneira molecular}

Os principais materiais utilizados nos processos de separação de misturas gasosas por adsorção são a sílica-gel, carvão ativo, alumina ativada, argilas ativadas e zeólitas. As zeólitas destacam-se entre as demais devido a sua estrutura cristalina apresentar poros com um único diâmetro ao contrário dos demais adsorventes com tamanhos variáveis.

Trabalhando com zeólitas é possível fabricar um adsorvente específico a uma dada separação pela escolha apropriada do cátion trocável. Desde que a estrutura cristalina de uma zeólita seja suficientemente aberta para admitir moléculas de substâncias a serem adsorvidas, a quantidade de moléculas adsorvidas por unidade de massa de zeólita é função somente da pressão de vapor das moléculas e da temperatura. A facilidade da entrada destas moléculas na estrutura cristalina depende das seguintes variáveis:

- Tamanho e forma das aberturas de entrada dos canais e cavidades das zeólitas. 
- Tamanho e forma das moléculas a serem adsorvidas.

- Número, tipo de sítios e tamanho dos cátions trocáveis.

- Presença ou ausência de defeitos na estrutura cristalina.

- Presença de resíduos deixados nos canais durante a síntese, ou introduzidos subseqüentemente.

- Presença de outras moléculas fortemente adsorvidas como água, amônia e sais.

Um exemplo de uso de zeólitas como peneira molecular é a chabazita que é usada como absorvedor de $\mathrm{SO}_{2}$ das chaminés. Outro exemplo é a zeólita A que admite a molécula do metano, mas exclui a do benzeno que é maior.

\subsubsection{Catalisador}

As zeólitas são catalisadores muito úteis possuindo várias propriedades importantes que não são achadas nos catalisadores tradicionais amorfos.(Lesley et al.,1992).

A propriedade catalítica de um composto está relacionada principalmente com a sua morfologia, superfície ativa, com o sistema interno de passagens e vazios, o tamanho das cavidades internas, estabilidade térmica e a propriedade de troca catiônica. Isto leva a uma reação de catálise por seleção de forma, que ocorre dentro do sistema de microporo (Grieken et al.,2000). Na Tabela 1, está descrita a relação entre a propriedade da zeólita e a sua função catalítica.

Tabela 1 - Relação entre a propriedade da zeólita e o efeito catalítico.

\begin{tabular}{|l|l|}
\hline \multicolumn{1}{l}{ Propriedade } & Funcionalidade catalítica \\
\hline Vazios cristalinos & $\begin{array}{l}\text { Superfície interna extensa que encoraja o processo } \\
\text { catalítico. }\end{array}$ \\
\hline $\begin{array}{l}\text { Variação de } \\
\text { tamanho de poro }\end{array}$ & $\begin{array}{l}\text { Cria a seletividade de regentes e produtos via peneira } \\
\text { molecular. }\end{array}$ \\
\hline Troca iônica & $\begin{array}{l}\text { O cátion controla o tamanho do poro, criando campos de } \\
\text { alta energia potencial dentro dos vazios (sítios ativos) e } \\
\text { permitem a distribuição dos metais cataliticamente ativos } \\
\text { no substrato da zeólita. }\end{array}$ \\
\hline Oclusão de sais & $\begin{array}{l}\text { Controla o tamanho do poro, fornece um outro método } \\
\text { da incorporação do metal e pode melhorar a estabilidade } \\
\text { térmica. }\end{array}$ \\
\hline $\begin{array}{l}\text { Modificação da } \\
\text { estrutura } \\
\text { cristalina }\end{array}$ & $\begin{array}{l}\text { Varia a carga do retículo (por síntese ou modificação) } \\
\text { para melhorar a produção de sítios ativos e estabilidade } \\
\text { térmica. }\end{array}$ \\
\hline
\end{tabular}


A maioria das aplicações da zeólita para catálise são baseadas em tecnologias adaptadas dos catalisadores ácidos sílica/alumina, originalmente desenvolvidos para reações de craqueamento. Isto significa que a atividade requerida é baseada na produção de sítios Brønsted que surgem da criação de cátions de hidrogênio dentro da estrutura porosa. Estes cátions são usualmente formados tanto pela troca catiônica da amônia ou cátion polivalente seguido de calcinação. Sítios Lewis podem ser criados também, expondo o íon $\mathrm{Al}^{+3}$ tricoordenado, que tem propriedades receptoras de par eletrônico (Lesley \& Moore., 1992).

Existem três tipos de catálise por seleção de forma nas zeólitas:

- Catálise por seleção de reagentes (Figura 5a): somente moléculas com dimensões menores que o tamanho crítico podem entrar nos poros alcançar as posições de catálise e,em seguida, reagir.

- Catálise por seleção de produto: somente produtos menores que certas dimensões podem deixar as posições ativas e difundir para fora através dos canais. Como ilustrado na Figura $5 \mathrm{~b}$ na preparação do xileno, a mistura dos três isômeros é formada na cavidade, mas somente a forma "para" consegue sair do canal.

- Catálise de restrição do estado de transição: certas reações são evitadas porque o estado de transição requer mais espaço do que o disponível na cavidade, como mostrado na Figura $5 \mathrm{c}$, na transalquilação do dialquilbenzeno somente ocorre a reação que necessita de menor espaço.

Uma alta relação Si/Al favorece o craqueamento catalítico, resistência a ácidos e estabilidade térmica.

A Tabela 2 mostra as principais zeólitas usadas como catalisador, sua função e vantagens. Destaca-se a indústria petroquímica como a grande consumidora de zeólitas para esta função. 
Seleção de reagente

a)

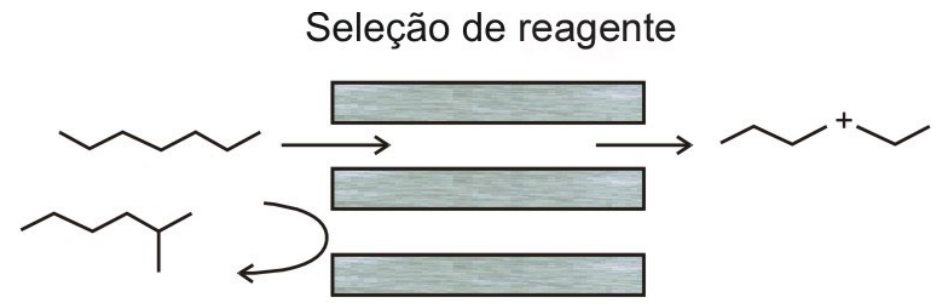

Seleção de produto

b) $\mathrm{CH}_{3} \mathrm{OH}+$ 으-

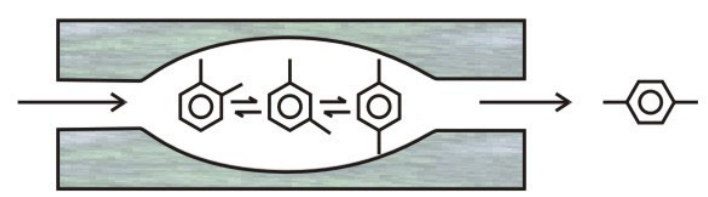

Seleção de restrição do estado de transição

c)
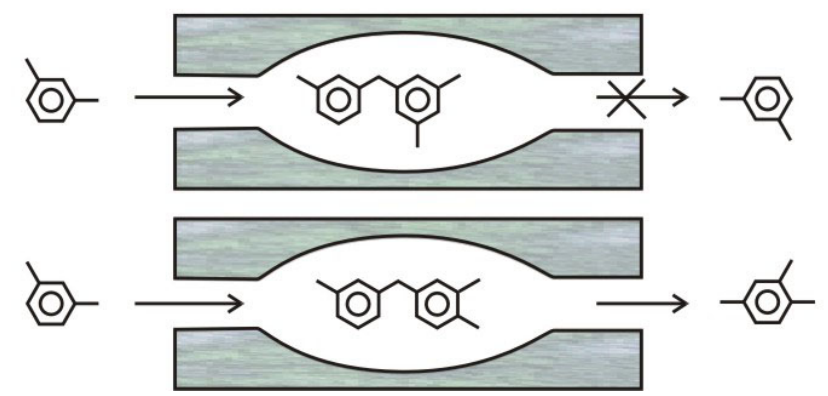

Figura 5 - Catálise por seleção de forma. (a) seleção de reagente (b) seleção de produto e (c) seleção de reação(Lesley \& Moore., 1992).

Tabela 2 - Relação e vantagens das principais zeólitas usadas atualmente como catalisador (Dyer., 1988).

Processo

Catalisador

Vantagem da zeólita

\begin{tabular}{|c|c|c|}
\hline $\begin{array}{l}\text { Craqueamento } \\
\text { catalítico. }\end{array}$ & $\begin{array}{l}\text { REY, REX, } \\
\text { HY }\end{array}$ & $\begin{array}{l}\text { Seletividade } \\
\text { e altas taxas } \\
\text { de } \\
\text { conversão. }\end{array}$ \\
\hline Hidrocraqueamento. & $\begin{array}{l}\mathrm{X}, \mathrm{Y}, \\
\text { Mordenita, H- } \\
\text { ZSM-5 }\end{array}$ & $\begin{array}{l}\text { Altas taxas } \\
\text { de conversão }\end{array}$ \\
\hline Seleção de forma. & $\begin{array}{l}\text { Ni-Erionita, } \\
\text { Clinoptilolita }\end{array}$ & $\begin{array}{l}\text { Aumento de } \\
\text { numero de } \\
\text { octanos via } \\
\text { produção } \\
\text { LPG. }\end{array}$ \\
\hline Hidroisomerização. & Pt-Mordenita & $\begin{array}{l}\text { Converte } \\
\text { baixa } \\
\text { alimentação } \\
\text { de octano, } \\
\text { pentano e } \\
\text { hexano em } \\
\text { alto } \\
\text { rendimento }\end{array}$ \\
\hline
\end{tabular}




\begin{tabular}{|c|c|c|}
\hline & & de octano. \\
\hline Desparafinação & $\begin{array}{l}\text { Pt-Mordenita, } \\
\text { ZSM-5 }\end{array}$ & $\begin{array}{l}\text { Melhora } \\
\text { pontos } \\
\text { pobres. }\end{array}$ \\
\hline $\begin{array}{l}\text { Alquilação do } \\
\text { benzeno }\end{array}$ & ZSM-5 & $\begin{array}{l}\text { Produção de } \\
\text { Etilbenzeno e } \\
\text { Estireno com } \\
\text { baixa } \\
\text { produção de } \\
\text { co-produtos }\end{array}$ \\
\hline $\begin{array}{l}\text { Isomerização do } \\
\text { xileno }\end{array}$ & ZSM-5 & $\begin{array}{l}\text { Aumenta a } \\
\text { produção do } \\
\text { p-xileno }\end{array}$ \\
\hline $\begin{array}{l}\text { Conversão do } \\
\text { metanol para } \\
\text { gasolina }\end{array}$ & ZSM-5 & $\begin{array}{l}\text { Alta } \\
\text { produção de } \\
\text { gasolina com } \\
\text { alta taxa de } \\
\text { octano. }\end{array}$ \\
\hline Redução $\mathrm{NO}_{\mathrm{X}}$ & H-Mordenita & $\begin{array}{l}\text { Limpeza de } \\
\text { efluentes e } \\
\text { reprocessam } \\
\text { ento de } \\
\text { plantas } \\
\text { nucleares }\end{array}$ \\
\hline
\end{tabular}

\subsubsection{Nucleação e cristalização.}

O comportamento da síntese da zeólita é complexo devido a um delicado jogo de variáveis. Várias zeólitas diferentes podem cristalizar no sistema $\mathrm{Na}_{2} \mathrm{O}-\mathrm{SiO}_{2}-\mathrm{Al}_{2} \mathrm{O}_{3}-\mathrm{H}_{2} \mathrm{O}$. A mistura reacional inicial é um sistema complexo, fora do equilíbrio e muitas vezes com várias fases (Sefcik \& McCormick., 1999).

Na síntese de zeólitas, as variáveis termodinâmicas importantes a serem controladas são: temperatura, pressão e composição dos regentes. Contudo, nas reações hidrotérmicas, devido à fase reagente ser heterogênea na maioria dos casos e a nucleação parece ser determinada e controlada cinéticamente, ao invés de termodinamicamente, só o controle das variáveis acima relacionados não determina os produtos a serem obtidos (Tome et al.,1995). Existem outros fatores não termodinâmicos, tais como: tratamento dos reagentes antes da reação, natureza física e química dos reagentes, mineralizadores, aditivos e modeladores ou templates (cátions que vão servir de suporte e ordenação na cristalização de zeólitas). As condições geralmente usadas na síntese são: 
- Reagentes com alta reatividade, como géis recentemente coprecipitados ou sólidos amorfos.

- $\mathrm{pH}$ relativamente alto conseguido na forma de um hidróxido de metal alcalino ou outra base forte.

- Condições hidrotérmicas de baixa temperatura, com conseqüente baixa pressão autógena em pressão de vapor saturada.

- Alto grau de supersaturação dos componentes no gel, conduzindo a nucleação de um grande número de cristais.

O gel é definido como um aluminossilicato hidratado que é preparado tanto de soluções aquosas, sólidos reativos, sois coloidais ou aluminossilicatos reativos.

Durante a reação hidrotérmica é formada, na presença de agentes mineralizadores (como por exemplo, hidróxido de metal alcalino), uma zeólita contendo ligações Si-O-Al. Nenhuma grande mudança de entalpia pode ocorrer desde que os tipos de ligações do produto são muito similares às existentes nos óxidos precursores. De fato, a mudança total de energia livre na síntese da zeólita é usualmente bem pequena, então o resultado é freqüentemente controlado de maneira cinética (Cox et al.,2005).

A cristalização de soluções geralmente ocorre via etapas seqüenciais de nucleação da fase, ou fases, ditados pela composição da solução, seguido do crescimento do núcleo pela incorporação de material da solução. A nucleação e a taxa de crescimento do cristal são governadas pela força motriz relacionada à supersaturação (Thompson.,2001).

Em sistemas hidrotérmicos para a nucleação da zeólita é mais difícil identificar a "supersaturação" devido a grande quantidade de espécies presentes na solução de aluminossilicato, a função dos agentes direcionadores em alguns casos e, também, às concentrações variáveis no sistema com a cristalização. Por estas razões, a definição da força motriz na nucleação da zeólita e crescimento do cristal ainda precisa ser aperfeiçoada.

A nucleação primária é caracterizada como sendo conduzida pela própria solução, ou estritamente dentro da solução, como numa nucleação homogênea, ou catalisada por materiais estranhos a solução, como numa nucleação heterogênea. Certamente, com a presença do gel amorfo na maioria 
dos sistemas de nucleação de zeólitas pode-se prever que a nucleação heterogênea na superfície do gel pode ser importante.

A nucleação secundária é catalisada pela presença de cristais fontes da mesma fase, e ocorre com uma menor energia de ativação que a nucleação primária. Os cristais fontes podem ser adicionados como cristais sementes no inicio da síntese.

A cristalização da zeólita é um fenômeno muito complexo que não pode ser adequadamente descrito somente pelas variáveis na composição dos reagentes, temperatura e pressão. A cristalização também envolve polimerização-despolimerização (Figura 6), solução-precipitação, nucleaçãocristalização e outros fenômenos complexos encontrados numa dispersão coloidal aquosa (Wilson.,2001).

\section{Modelador (Templating)}

Nas primeiras descrições da síntese de zeólitas, as espécies que formam a estrutura dos óxidos são diferenciadas das espécies extra estruturais como os cátions permutáveis e a água. Obviamente, os cátions têm um importante papel na compensação de carga do tetraedro de alumínio. Menos óbvio, a associação freqüente de certos cátions alcalinos com a presença de estruturas pequenas em "cela" levam a um conceito de um papel mecânico que foi designado como "modelamento" ou templating. Modeladores são espécies catiônicas adicionadas ao meio da síntese para guiar na organização da polimerização dos blocos de construção aniônicos que formam a estrutura.

As características únicas estruturais da zeólita contendo celas poliédricas têm levado a postulação que os cátions estabilizam a formação estrutural das sub-unidades que são os precursores ou espécies nucleadoras na cristalização.

Na década de 80 foram feitas revisões do papel das moléculas orgânicas na síntese de zeólitas, no mesmo tempo em que muitas das estruturas novas eram resultados da síntese na presença de diferentes cátions quartenários de amônia ou aminas (Rubin et al.,1979). A distribuição de cargas e o tamanho e forma geométrica do padrão foram invocados para explicar a ordem estrutural. Já se sabe que em alguns casos: a) Um modelador pode resultar em diferentes estruturas cristalinas, b) Vários modeladores podem resultar na mesma estrutura e c) Algumas estruturas necessitam da presença 
de um modelador específico. A solução para este dilema é a ação conjunta do modelador e da "química do gel" onde esta última representa todos os outros parâmetros que governam o gel, como a composição dos óxidos, temperatura, tempo, tipo do reagente e $\mathrm{pH}$. O modelador é necessário, mas não condição suficiente para a formação da estrutura.

\section{Tempo e temperatura}

Tempo e temperatura tem uma influência positiva no processo de formação da zeólita, que ocorre sob uma considerável faixa de temperatura. Baseado em evidências geológicas, um limite máximo de $350^{\circ} \mathrm{C}$ foi sugerido. Mas a analcima tem sido obtida a $365^{\circ} \mathrm{C}$, mordenita a $430^{\circ} \mathrm{C}$ e ferrierita a $375^{\circ} \mathrm{C}$.

Um aumento na temperatura irá aumentar tanto a taxa de nucleação como de crescimento linear. Mas, a síntese das zeólitas é governada pela ocorrência de sucessivas transformações de fase. Muitas substâncias que podem existir em várias formas polimorficas tendem a cristalizar-se inicialmente na forma de mais alta temperatura de modificação e termodinamicamente menos favorável, de acordo com a regra de Ostwald (Breck.,1984). 


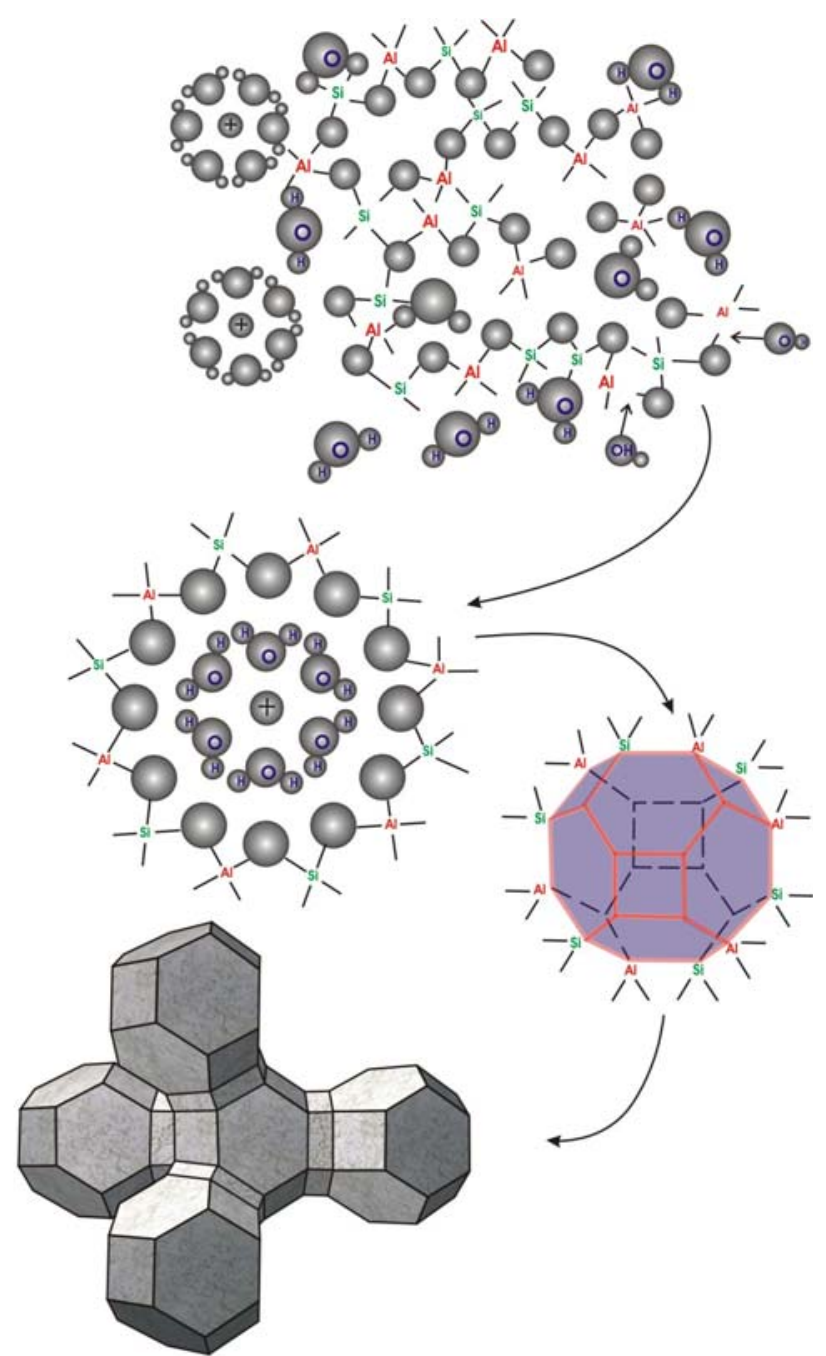

Figura 6 - Representação esquemática da formação do núcleo no gel reacional. A estrutura do gel é despolimerizada pelos íons $\mathrm{OH}^{-}$. Os tetraedros se reagrupam sobre os íons do cátions hidratados para formar as unidades básicas poliédricas(Cox \& Cundy.,2005).

A cristalização de silicatos oriundos de géis reativos pode ser discutida em termos das relações de energia livre (Figura 7). A mistura reacional inicial tem componentes que primeiro formam a fase $a$, que pode se converter $a, b$ ou $c$ no tempo. Na região que a temperatura é tal que $a$ ou $b$ podem se formar, a nucleação e taxa de crescimento podem ser importantes. A fase metaestável a se forma preferencialmente e pode se transformar nas fases $b$ e $c$ mais estáveis.

Um aumento na temperatura leva a cristalização de fases mais densas porque a fração de água na fase líquida, que estabiliza o produto preenchendo os poros, irá sair. Por esta razão, a existência de um limite máximo na formação de zeólitas pode ser previsto. $\mathrm{O}$ uso de substâncias não 
voláteis fazendo este papel, em princípio, permitem a síntese de estruturas abertas em maior temperatura.

O efeito da composição total da mistura reacional na zeólita final está usualmente presente na forma de diagramas de cristalização. Tem sido especulado que as regiões nestes diagramas simplesmente correspondem à composição necessária para a nucleação de uma fase particular. Se de fato apenas uma única zeólita pode nuclear a uma dada composição, então a dinâmica da cristalização competitiva poderia ser totalmente determinada pelo processo de nucleação. Durante o crescimento da zeólita a composição da mistura reacional pode mudar e eventualmente pode entrar na região de nucleação de outra zeólita. Então um segundo produto pode aparecer e crescer causando a dissolução do primeiro (Sefcik et al., 1999).

Uma zeólita natural que existiu por longos períodos geológicos e uma zeólita sintética de mesma estrutura, mas que foi sintetizada rapidamente no laboratório podem exibir diferenças nas propriedades devido a ordenação que pode ocorrer no mineral em relação a falta da mesma na versão sintética. É provável que muitas das zeólitas sintéticas que não tem sua versão natural são fases fora do equilíbrio, e que não existem quando as condições de equilíbrio são alcançadas.

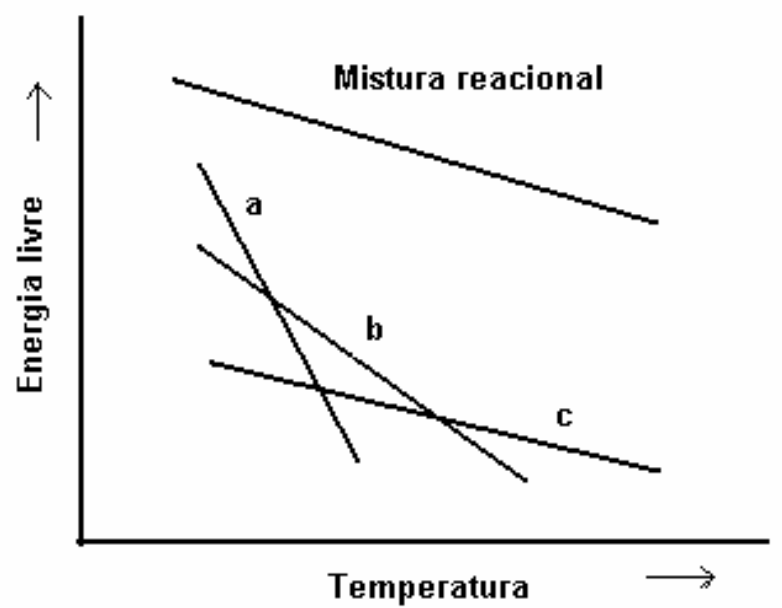

Figura 7 - Relações de energia livre esquemática entre várias fases zeolíticas.

\section{pH}

A alcalinidade da solução de síntese é o mais importante parâmetro para o controle da cristalização da zeólita. Ele determina a composição e é em 
grande parte responsável pelo tipo de fase no produto cristalizado (Lechert.,2000).

A mistura reacional pode ser descrita pela fórmula:

$$
\mathrm{MAIO}_{2} \mathrm{n}\left[\mathrm{M}_{\mathrm{m}} \mathrm{H}_{4-\mathrm{m}} \mathrm{SiO}_{4}\right] \mathrm{pH}_{2} \mathrm{O}
$$

O excesso de alcalinidade $(\mathrm{m})$ nesta formula é a diferença entre a alcalinidade total $(\mathrm{MOH})$ e o óxido de alumínio alcalino $\left(\mathrm{MAIO}_{2}\right)$ por mole de $\mathrm{SiO}_{2}$

$$
\mathrm{m}=\left(\mathrm{MOH}-\mathrm{MAIO}_{2}\right) / \mathrm{SiO}_{2}
$$

$\mathrm{O}$ valor do $\mathrm{pH}$ têm sido discutido em poucos trabalhos em conexão com os parâmetros de cristalização. Geralmente, diferentes zeólitas cristalizam dentro de estreitas faixas de $\mathrm{pH}$.

$\mathrm{O}$ pH influencia a supersaturação, cinética, morfologia, tamanho e cristalinidade do material, com os ânions $\mathrm{OH}^{-}$preenchendo um papel fundamental como agente mineralizador. Um aumento na concentração das hidroxilas geralmente irá acelerar o crescimento do cristal e diminuir o período de indução na formação de um núcleo viável.

Na síntese das zeólitas, o pH é usualmente de 8 a 12. A maior função do pH é associar na solução, os óxidos de Al e Si ou hidróxidos, a uma velocidade adequada (Byrappa et al.,2001).

$\mathrm{O}$ íon $\mathrm{OH}^{-}$é um bom agente complexante. A solubilidade da sílica cresce quase que exponencialmente com a concentração alcalina e, na mistura resultante, uma faixa de ânions de silicato podem aparecer com vários graus de oligomerização. No caso da alumina em alto pH há uma mínima oligomerização, existe um ânion dominante, sempre o $\mathrm{Al}(\mathrm{OH})_{4}^{-}$.

\section{Aspectos cinéticos.}

Vários mecanismos tem sido propostos para descrever a cinética do crescimento de cristais em soluções, isto juntamente com a teoria do controle de filme, primeiro definido por Nerst, é o que é mais usado para interpretar e predizer a taxa de crescimento de cristais de muitos sólidos, incluindo zeólitas (Cardew et al.,1985). Entretanto a equação de Nerst, descrita abaixo, é falha em descrever a cinética do crescimento do cristal em vários casos (Cook et al., 1988). 


$$
\frac{d L}{d t_{c}}=\frac{D\left(C-C^{*}\right)}{V \delta}=k_{1}\left(C-C^{*}\right)
$$

onde:

$L=$ tamanho do cristal.

$t_{c}=$ tempo de cristalização

$D=$ coeficiente de difusão dos íons ou moléculas na solução

$C=$ concentração do sal na solução

$C^{*}=$ solubilidade do sal

$V=$ volume da solução

$\delta=$ espessura da camada limite hidrodinâmica

A equação:

$$
\frac{d L}{d t_{c}}=k_{2}\left(C-C^{*}\right)^{n}
$$

Onde $n=a+b$ para o retículo cristalino $\mathrm{A}_{a} \mathrm{~B}_{b}$ foi proposta por Davis e Jones.

Aplicando os argumentos cinéticos convencionais para o crescimento superficial controlado do sólido $A_{a} B_{b}$, isto é:

$a \mathrm{~A}^{\mathrm{b+}}{ }_{(\mathrm{aq})}+b \mathrm{~B}^{\mathrm{a+}}{ }_{(\mathrm{aq})} \leftrightarrow \mathrm{A}_{a} \mathrm{~B}_{b}$

leva a:

$$
\frac{d L}{d t_{c}}=k_{3}\left[C^{n}-\left(C^{*}\right)^{n}\right]
$$

e por esta razão é falha em explicar a dependência da concentração na equação [2]. A relação entre a taxa de crescimento do cristal $d L / d t_{c}$ e a dependência da concentração na eq. [2] pode ser explicada pelo modelo de Davis e Jones de dissolução e crescimento, que prediz a formação de uma monocamada de íons solvatados com uma composição constante na superfície do cristal que esta crescendo/dissolvendo. Em conformidade com este modelo, a taxa de crescimento do cristal de um sólido $A_{a} B_{b}$ é proporcional ao produto de fluxo dos íons (ou moléculas) que participa na reação superficial. Então:

$$
\frac{d L}{d t_{c}}=k_{4}\left(C_{A}-C_{A}^{*}\right)^{a}\left(C_{B}-C_{B}^{*}\right)^{b}
$$

Tal crescimento de cristal controlado pela reação superficial é característico de sistemas bem agitados, no qual o gradiente de concentração de 
espécies reativas não pode ser formado em torno do cristal em crescimento. Entretanto, em muitos sistemas de cristalização o incremento é dependente do tamanho, que pode ser calculado pela relação empírica de Bransom.

$$
\frac{d L}{d t_{c}}=k_{g} f(C) / L_{m}
$$

onde $f(C)$ é o termo de concentração nas equações 1 à $4, k_{g}$ é a taxa constante de crescimento e $m$ é a constante relacionada as condições hidrodinâmicas da suspensão, isto é, o modo e intensidade da agitação.

Existem abundantes evidências experimentais que o tamanho do cristal de zeólita aumenta linearmente durante a maior parte do processo de cristalização, tanto do gel como da solução de aluminossilicato, isto é:

$$
L=K_{g} t_{c}
$$

Onde $K_{g}$ é a taxa constante.

Entretanto, a taxa de crescimento do cristal começa a decrescer no final do processo de cristalização, e o cristal alcança o seu tamanho final quando o aluminossilicato amorfo é completamente dissolvido e as concentrações de aluminato, silicato e aluminossilicatos na fase líquida alcançam seus valores característicos para a solubilidade da zeólita formada sob uma dada condição de síntese (Falamaki et al.,1987). O perfil específico da curva $L x t_{c}$ é causado pela constância da mudança relativamente pequena na concentração do alumínio e silício na fase líquida (isto é, $f(C) \approx c o n s t a n t e$ durante a maior parte do processo de cristalização), e sua rápida mudança no final do processo de cristalização.

Baseado em descoberta que: (1) o crescimento dos cristais de zeólitas são independentes do tamanho, (2) o crescimento do cristal de zeólita é governado pela reação de um ín aluminato, silicato ou aluminossilicato monomérico da fase líquida na superfície do cristal em crescimento e (3) existe uma analogia entre a dissolução e o crescimento do cristal (Buckley.,1950), foi postulado que o crescimento cristalino das zeólitas está de acordo com o modelo de Davies e Jones para crescimento e dissolução. Então, levando-se em consideração as particularidades do sistema de crescimento das zeólitas, a cinética do crescimento das zeólita pode ser definido como:

$$
\frac{d L}{d t_{c}}=k_{g}\left(C_{A l}-C_{A l}^{*}\right)\left(C_{S i}-C_{S i}^{*}\right)^{r}
$$


onde:

$C_{A l}$ e $C_{S i}=$ concentração de alumínio e silício na fase líquida.

$C^{*}{ }_{A l}$ e $C^{*}{ }_{S i}=$ concentração de alumínio e silício na fase líquida que corresponde a solubilidade da zeólita em uma dada condição de cristalização.

$r=$ relação molar Si/Al da zeólita cristalizada.

\section{Nanocristais.}

Recentemente a síntese de zeólitas nanocristalinas tem recebido muita atenção, isto é em parte devido ao interesse no crescimento do cristal. Entretanto, a principal razão é que a síntese de zeólitas nanocristalinas pode ser usada, por exemplo, em filmes ultra-finos, membranas e nanocompósitos (Rakoczy et al.,2003).

\section{Impurezas}

A síntese da zeólita está sujeita a perturbações causadas por impurezas presentes nas matérias-primas. Tais contaminantes podem permanecer insolúveis durante a cristalização e causar a nucleação de espécies indesejadas. Eles podem também ser solúveis e resultar na formação de diferentes silicatos e metassilicatos na solução, ou podem causar a precipitação de silicatos insolúveis. Por isto é desejado o uso de produtos químicos puros como material de partida (Kühl.,2001).

A maioria dos laboratórios na síntese da zeólita usam aluminatos de um metal para prover o alumínio na mistura reacional. Alternativamente são usados $\mathrm{Al}(\mathrm{OH})_{3}, \mathrm{Al}_{2} \mathrm{O}_{3}$ e $\mathrm{AlO}(\mathrm{OH})$. Algumas sínteses usam sais de alumínio (particularmente sulfato) ou mesmo fontes naturais de alumínio de vidros, sedimentos, feldspatos e feldspatóides. A desvantagem de usar sais é que, após o ajuste do pH ou adição de soluções de silicato alcalino, sais alcalinos são formados no qual tem um forte efeito eletrolítico na formação do gel. Por exemplo, alguns sais podem causar a cristalização da sodalita ao invés da zeólita A. Por esta razão é vantajoso, particularmente em misturas de baixa relação $\mathrm{SiO}_{2} / \mathrm{Al}_{2} \mathrm{O}_{3}$, introduzir o alumínio na forma aniônica.

As mais usadas fontes de silício são silicatos solúveis e seus hidratos (ex. metasilicato de sódio pentahidratado), sílica sol feito de sílicas com alta área superficial. Menos freqüente é o uso de sílica gel e vidros (incluindo vidros vulcânicos), argilas (ex. caolinita), areia e quartzo. 
Desde que a composição da mistura reacional é dada na relação de óxidos, qualquer hidróxido empregado é considerado como óxido mais água, por exemplo, $\mathrm{NaOH}=1 / 2 \mathrm{Na}_{2} \mathrm{O}+1 / 2 \mathrm{H}_{2} \mathrm{O}$ (22,5\% em peso de água). A quantidade de água nas matérias-primas pode-se constituir em uma importante fração do total de água, por isto tem que ser calculada.

Vários outros fatores podem influenciar na síntese da zeólita. Muitos estudos tratam da influência de pequenas quantidades de sais (sais de ferro devem ser excluídos da síntese) (Dyer.,1988). Outros estudos tratam da influência da agitação da mistura reacional antes e durante a cristalização e também do uso de recipientes de vidro que são atacados pela mistura alcalina e pode reter pequenos cristais alternado o curso da síntese seguinte.

\subsubsection{Aplicações e mercado.}

Por muitos anos as zeólitas têm sido úteis para troca iônica seletiva, abrandamento de água e peneiras moleculares para separar moléculas de diferentes tamanhos e formatos. Recentemente, entretanto, pesquisas têm focado sua habilidade de agir como catalisadores em uma larga variedade de reações, muitas delas extremamente específicas, e elas são agora extensivamente usadas na indústria com este propósito. Aproximadamente 40 zeólitas naturais tem sido caracterizadas, mas na busca de novos catalisadores mais de 150 estruturas sintéticas tem sido desenvolvidas. A zeólita natural não tem o sucesso comercial da sintética. Estas últimas tem preferência porque são monominerálicas, apresentam um único tipo de cátion com capacidade de troca prevista, têm poucas impurezas e poros, e apresentam canais e cavidades com dimensões préestabelecidas. A única vantagem da zeólita natural é o preço (Holmes., 1997).

As principais áreas de uso das zeólitas são a agricultura, nutrição animal, aqüicultura, catálise e refino de petróleo, gaseificação do carvão, dessecadores, separação gasosa, processos de troca iônica, aplicações médicas, purificação de gás natural, tratamento de resíduos nucleares, controle de odor, limpeza de derramamento de óleo, carga de papel, tratamento de esgoto e energia solar.

Embora exista um mercado da ordem de 500.000 t/ano, grande porcentagem de seu uso é devido às propriedades não inerentes ao seu caráter zeolítico, por exemplo, blocos para construção civil. Seu forte interesse comercial 
começou após a década de 60 . Os principais fornecedores de zeólitas naturais são: EUA, Japão, Itália, Hungria, Bulgária, México, Cuba e Alemanha. Zeólitas sintéticas são produzidas principalmente pelo EUA, Inglaterra e Alemanha.

O preço da zeólita depende principalmente do tipo e grau de processamento que precisa ser feito para satisfazer um mercado específico. A maioria das zeólitas naturais é vendida por 30 a 70 US $\$$ /t com granulometria abaixo de 40 mesh, e 50 a 120 US $\$ / t$ no intervalo de 40 a 325 mesh. Os produtos sintéticos com aplicações industriais bem específicas, como filtro para resíduo radioativo ou catalisadores no refino de petróleo (Mordenita-Pt na hidroisomerização), podem ter valores chegando a milhares de dólares a tonelada, apesar de sua demanda ser bem limitada (Holmes.,1997).

O Japão usa cerca de 6.000 toneladas por ano de clinoptilolita e mordenita para controlar o $\mathrm{pH}$, umidade e odor do solo na agricultura. O controle do $\mathrm{pH}$ é relacionado à habilidade da zeólita de melhorar a retenção do nitrogênio no solo. Experimentos em laboratório têm mostrado que a zeólita $A$ tem o mesmo efeito benéfico. $O$ custo decrescente da zeólita $A$ está tornando-a interessante para o uso na agricultura mesmo em áreas onde existem zeólitas naturais disponíveis.

A indústria de catalisadores representa um faturamento mundial de cerca de US\$ 8 bilhões, divididos em partes mais ou menos iguais entre refino, química/petroquímica, polimerização e meio ambiente (sobretudo os automotivos). O consumo atual das zeólitas sintéticas nos processos químicos catalíticos corresponde a $40 \%$ da necessidade mundial de catalisadores (Fernandes et al.,1988) Os segmentos dessa indústria que mais crescem são o dos catalisadores para poliolefinas e a das zeólitas. Destes o mais promissor é o das aplicações mais sofisticadas, em que o catalisador pode custar até US\$200300/kg. (Hahn.,2000).

Algumas destas aplicações são puramente petroquímicas. Um bom exemplo é representado pelas reações de alcoilação, onde a produção mundial de alguns grandes intermediários, como etilbenzeno ou cumeno, caminha para $100 \%$ à base de catalisadores zeolíticos. Outras se colocam na zona limítrofe entre refino e petroquímica: à medida que as especificações para os combustíveis automotivos vão ficando mais severas, a composição das gasolinas começa a parecer mais uma mistura de produtos individuais do que uma simples "corrente", 
definida sobretudo pela sua faixa de ebulição. Essa tendência abre mais espaço para diversos processos catalisados por zeólitas: isomerização e transformação de benzeno (por exemplo, em metilciclopentano) são dois exemplos.

Outros processos, estes mais próximos da petroquímica, andam empolgando a indústria de catalisadores zeolíticos. Um deles é a conversão de GLP em aromáticos. Outra, de enorme interesse potencial, é a transformação de gás natural em gás de síntese e esse, por sua vez, em olefinas, passando ou não pelo metanol.

Os principais produtores de zeólitas para catálise são Zeolyst (join venture entre Shell e PQ, outrora Philadelphia Quartz), UOP (em parceria com Union Carbide) e Süd-Chemie, de Munique, Alemanha. E no Brasil, a Fábrica Carioca de Catalisadores no Rio de Janeiro (Petrobrás).

\subsubsection{Zeólita A}

A zeólita A descoberta por Milton e Breck em 1956 (Cundy et al.,2003) é de grande importância industrial tanto como adsorvente e aditivo em detergente e também para agricultura e ração animal.

A estrutura cristalina da zeólita A pode ser descrita em termos de dois tipos de poliedros; um de arranjo cúbico simples de oito tetraedros, o 4 ou D4R (Figura 4); o outro é o octaedro truncado de 24 tetraedros, que consiste de 12 tetraedros $\mathrm{AlO}_{2}$ e $12 \mathrm{SiO}_{2}$ (Figura 8). A cavidade resultante se chama $\beta$-cage. Quando totalmente hidratada, possui 27 moléculas de água.

Normalmente a zeólita $A$ é sintetizada tendo o sódio como cátion trocável. Outras formas catiônicas são preparadas por troca iônica em solução aquosa (Breck., 1984).

A preparação do gel e cristalização é representada esquematicamente usando o sistema $\mathrm{Na}_{2} \mathrm{O}-\mathrm{Al}_{2} \mathrm{O}_{3}-\mathrm{SiO}_{2}-\mathrm{H}_{2} \mathrm{O}$ como um exemplo:

$$
\begin{gathered}
\mathrm{NaOH}(\mathrm{aq})+\mathrm{NaAl}(\mathrm{OH})_{4}(\mathrm{aq})+\mathrm{Na}_{2} \mathrm{O} \cdot \mathrm{nSiO}_{2}(\mathrm{aq})+\mathrm{H}_{2} \mathrm{O} \\
\downarrow \mathrm{T} \approx 25^{\circ} \mathrm{C} \\
{\left[\mathrm{Na}_{a}\left(\mathrm{AlO}_{2}\right)_{\mathrm{b}}\left(\mathrm{SiO}_{2}\right)_{\mathrm{c}} \cdot \mathrm{NaOH} \cdot \mathrm{H}_{2} \mathrm{O}\right] \mathrm{gel}} \\
\downarrow \mathrm{T} \approx 25^{\circ} \mathrm{C} \text { a } 180^{\circ} \mathrm{C} \\
\mathrm{Na}_{\times}\left[\left(\mathrm{AlO}_{2}\right)_{\times}\left(\mathrm{SiO}_{2}\right)_{\mathrm{x}}\right] \cdot \mathrm{mH}_{2} \mathrm{O}+\text { solução. }
\end{gathered}
$$




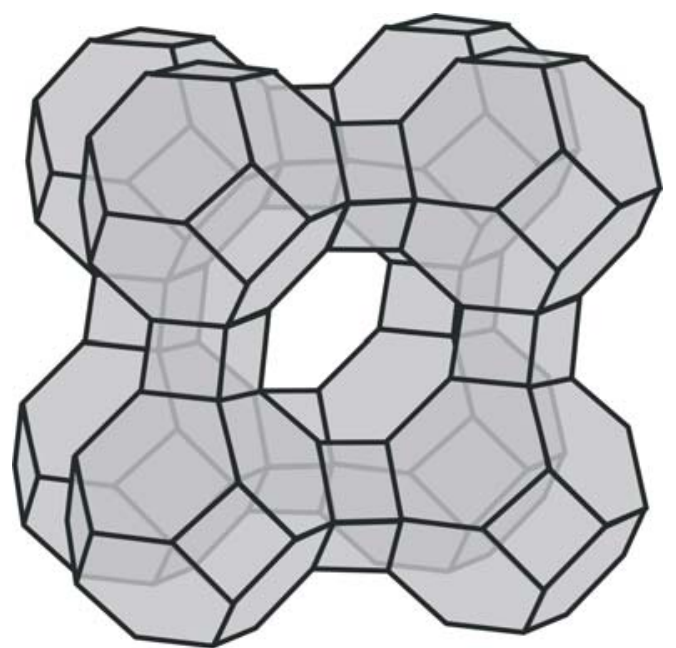

Figura 8 - Vista da estrutura da zeólita A através da direção [001] (Lesley \& Moore.,1992).

Foi estabelecido um estudo relacionando a composição da mistura reacional no sistema $\mathrm{SiO}_{2}-\mathrm{Al}_{2} \mathrm{O}_{3}-\mathrm{Na}_{2} \mathrm{O}$ e a fase cristalina obtida (Figura 9).

Uma zeólita $A$ rica em sílica cristaliza-se bem em um período de 1 hora no qual é seguida de uma rápida conversão para hidroxisodalita. Isto é esperado também para composições rica em sódio ou muito básicas.

A zeólita $A$ é cristalizada a temperaturas que variam de 25 a $150^{\circ} \mathrm{C}$ com o tempo de cristalização variando de 3 horas a 14 dias. Se após a cristalização, a zeólita $\mathrm{A}$ permanece em contato com a água de cristalização ( 1N $\mathrm{NaOH})$ a recristalização para zeólita $P$ pode ocorrer. A zeólita $P$ tem formula $\mathrm{Na}_{6}\left[\left(\mathrm{AlO}_{2}\right)_{6}\left(\mathrm{SiO}_{2}\right)_{10}\right] \cdot 15 \mathrm{H}_{2} \mathrm{O}$ com abertura do canal de $3,5 \AA$ e estrutura estável, tem como unidade secundaria de construção a 4 ou S4R (Figura 4) (Breck., 1984).

Uma desvantagem de usar sais de alumínio é que, após o ajuste do $\mathrm{pH}$ ou adição de uma solução de silicato alcalino, são formados sais alcalinos que têm um forte efeito eletrolítico na formação do gel. Por exemplo, alguns sais podem causar a nucleação da sodalita ao invés da zeólita A. Por esta razão é vantajoso, particularmente para misturas reacionais de baixa relação $\mathrm{SiO}_{2} / \mathrm{Al}_{2} \mathrm{O}_{3}$, introduzir o alumínio na forma aniônica, isto é, o aluminato de sódio (Coker et al., 1995).

A sodalita tem como formula $\mathrm{Na}_{6}\left[\left(\mathrm{AlO}_{2}\right)_{6}\left(\mathrm{SiO}_{2}\right)_{6}\right] \cdot 7,5 \mathrm{H}_{2} \mathrm{O}$ com abertura de canal de 2,2A e unidade secundária de construção 6 ou S6R (Figura 4). 


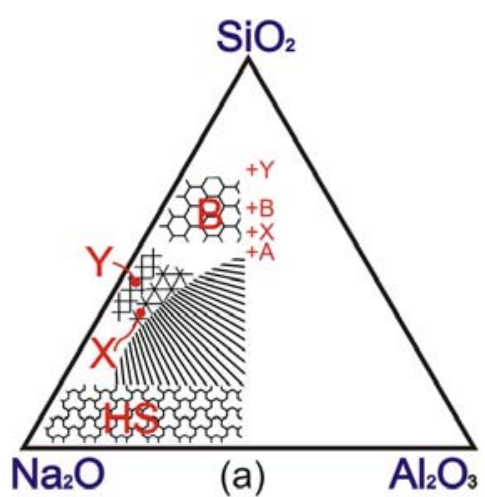

(a)

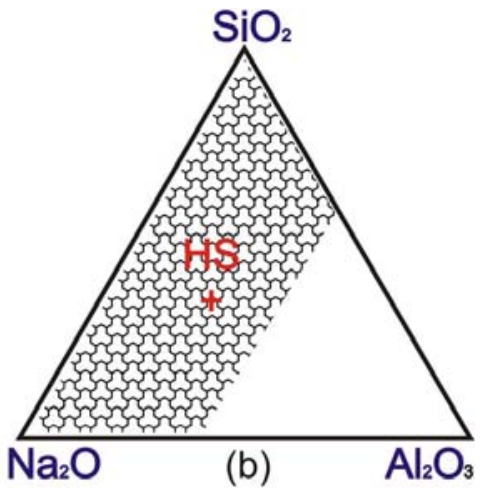

(b) $\quad \mathrm{Al}_{2} \mathrm{O}_{3}$

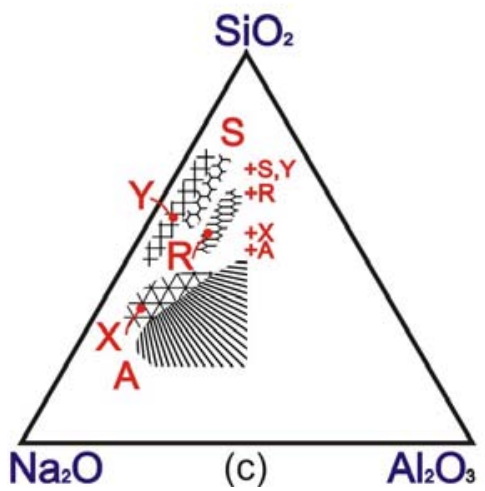

Figura 9 - Diagrama de fase da mistura reacional do sistema $\mathrm{SiO}_{2}-\mathrm{Al}_{2} \mathrm{O}_{3}-\mathrm{Na}_{2} \mathrm{O}$.

(a) Projeção a $100^{\circ} \mathrm{C} .90-98 \%$ molar de $\mathrm{H}_{2} \mathrm{O}$. Silicato de sódio usado como fonte de $\mathrm{SiO}_{2}$.

(b) Mesmo que (a) mas $60-85 \%$ molar de $\mathrm{H}_{2} \mathrm{O}$.

(c) Mesmo que (a) mas sílica coloidal usada como fonte de $\mathrm{SiO}_{2}$.

Marcas com + indicam a composição típica da fase obtida. (Breck.,1984).

A atividade do $\mathrm{SiO}_{2}$ na mistura depende do $\mathrm{pH}$. O aumento deste abaixa a atividade, então a síntese de zeólitas com alta relação $\mathrm{SiO}_{2} / \mathrm{Al}_{2} \mathrm{O}_{3}$ requerem baixo $\left[\mathrm{OH}^{-}\right]$.

Cerca de 30 anos atrás um aumento do controle dos danos ambientais criados pelo uso de polifosfatos em detergentes fizeram os produtores de detergentes procurarem substitutos. A função dos polifosfatos é melhorar a eficiência dos detergentes removendo os íons $\mathrm{Ca}^{2+}$ e $\circ \mathrm{Mg}^{2+}$ da água de lavagem prevenindo assim a sua precipitação pelas moléculas surfatantes. $O$ uso da zeólita foi sugerido na década de 70 e depois de muito estudo e uso a zeólita A foi escolhida como a mais efetiva.

\subsubsection{Zeólita ZSM-5}

Uma zeólita sintética de grande interesse industrial é a chamada zeólita Socony Mobil-5, ou simplesmente ZSM-5, em que o "5" significa o 
tamanho da abertura do poro em angstrom $\left(1 \hat{A}=10^{-10} \mathrm{~m}\right)$. Possui muitas aplicações industriais devido à sua alta seletividade em reações catalíticas e ao alto grau de estabilidade térmica e ácida. Caracteriza-se por um alto teor de silício (Si/Al>15) (Folletto et al.,2000). Apresenta a seguinte fórmula:

$$
\mathrm{M}_{\mathrm{n}} \mathrm{Al}_{\mathrm{n}} \mathrm{Si}_{(96-\mathrm{n})} \mathrm{O}_{192 .} .16 \mathrm{H}_{2} \mathrm{O}
$$

Sua estrutura é gerada de unidades do pentasil como outras zeólitas deste grupo. Estas unidades se conectam em cadeias que se juntam para formar camadas. Empilhamentos apropriados destas camadas resultam em varias estruturas pentasil (Figura 10). Tanto a ZSM-5 como a ZSM-11 são caracterizadas por canais controlados por janelas de 10 lados com diâmetros de cerca de 5,5Á (Figura 11).

O sistema de poros destas zeólitas não conectam grandes cavidades mas eles contém intersecções em que há maior espaço disponível para interações moleculares. A Figura 12 mostra a diferença das conexões dos canais nas zeólitas ZSM-5 e ZSM-11.

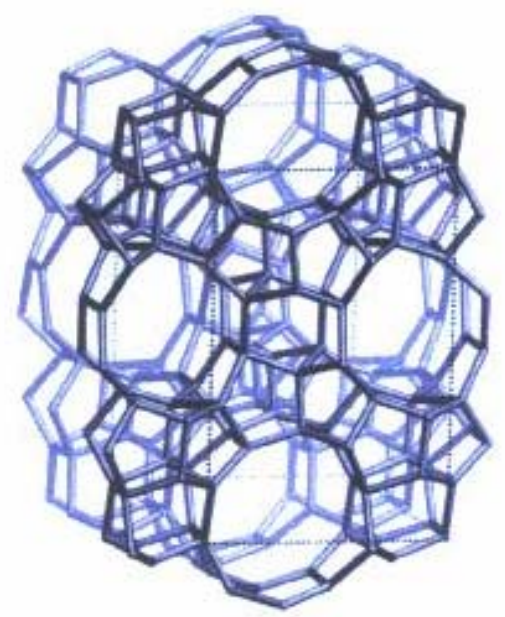

Figura 10 - Estrutura da ZSM-5 vista através da direção [010] (Baerlocher et al., 2001). 

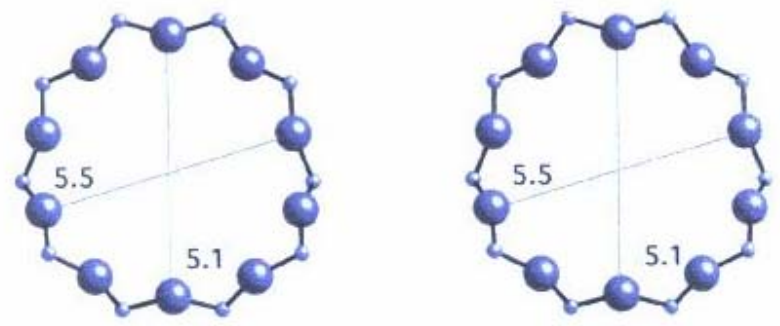

anel de 10 lados visto pela direção [100]
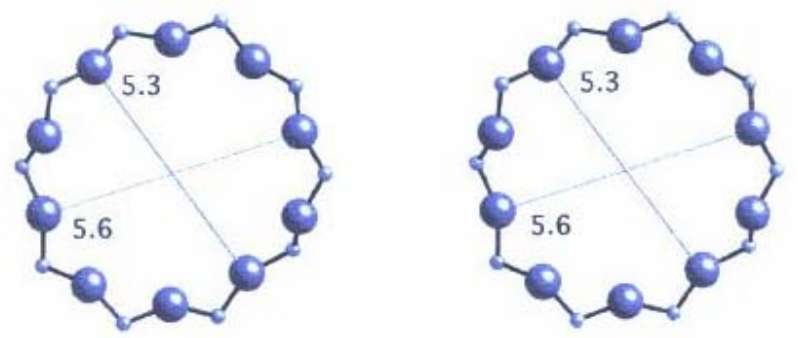

anel de 10 lados visto pela direção [010]

Figura 11 - Anéis das zeólita ZSM-5 e ZSM-11 visto nas direções [100] e [010] (Baerlocher et al., 2001).

ZSM-5

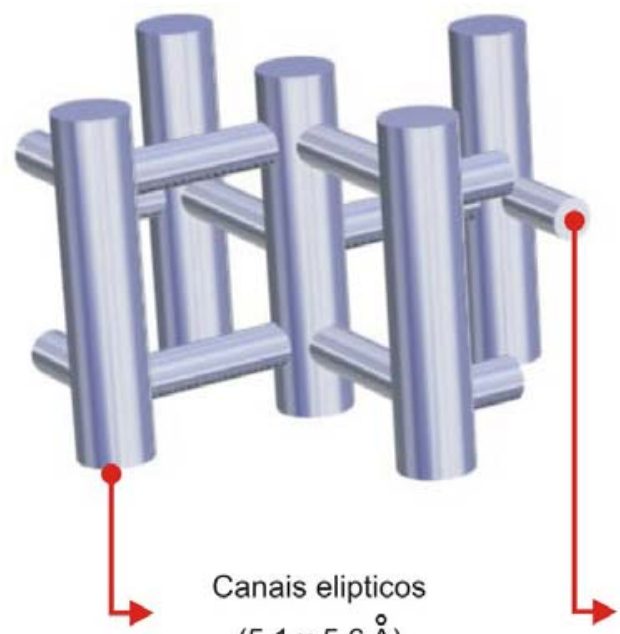

$(5,1 \times 5,6 \AA)$
ZSM-11

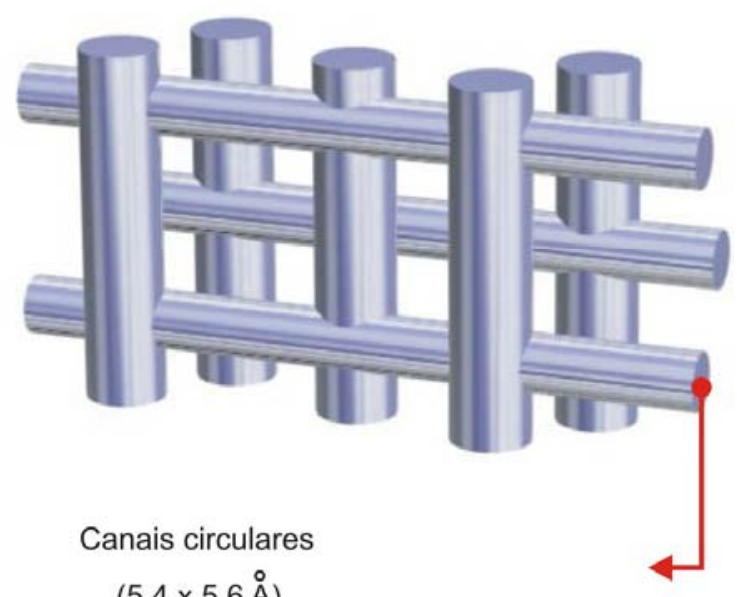

$(5,4 \times 5,6 \AA)$

Figura 12 - Diferença na disposição dos canais entre as zeólitas ZSM-5 e ZSM11. (Lesley \& Moore., 1992)

As primeiras ZSM-5 foram preparadas usando um modelador (template) na síntese da mistura que direciona a estrutura porosa da ZSM-5 e também controla a química do gel precursor (Lau et al.,1989). A estrutura final da ZSM-5 tem uma configuração do retículo cristalino que engloba três grupos funcionais básicos: $\mathrm{Al}_{2} \mathrm{O}_{3}, \mathrm{SiO}_{2}$ e $\mathrm{Na}_{2} \mathrm{O}$. Então, a ZSM-5 é geralmente descrita em termos destes grupos funcionais e suas razões relativas. As razões destes grupos, especialmente a razão molar $\mathrm{SiO}_{2} / \mathrm{Al}_{2} \mathrm{O}_{3}$, é um importante indicador 
das propriedades da zeólita. Resistência ácida e estabilidade térmica são beneficiadas com o aumento desta razão. Por outro lado, capacidade de adsorção e troca catiônica são prejudicadas com aumento desta relação (Cardoso et al.,1995).

Existem várias desvantagens em usar o modelador. Desde que a síntese da ZSM-5 deve ser feita sob pressão enquanto é aquecida, estes modeladores podem provocar danos ambientais se liberados para a atmosfera ou para o sistema de água. $O$ alto custo destes também encarecem o custo de produção da ZSM-5, sendo as vezes responsável por $50 \%$ do custo total. Remover o padrão, que é feito por combustão do material, pode resultar em degradação do retículo cristalino (Vempati.,2002). Então um processo para produzir ZSM-5 sem o modelador é desejável.

Um padrão típico usado na cristalização da ZSM-5 é o cátion de tetrapropilamônio (TPA) que direciona a cristalização (Figura 13).

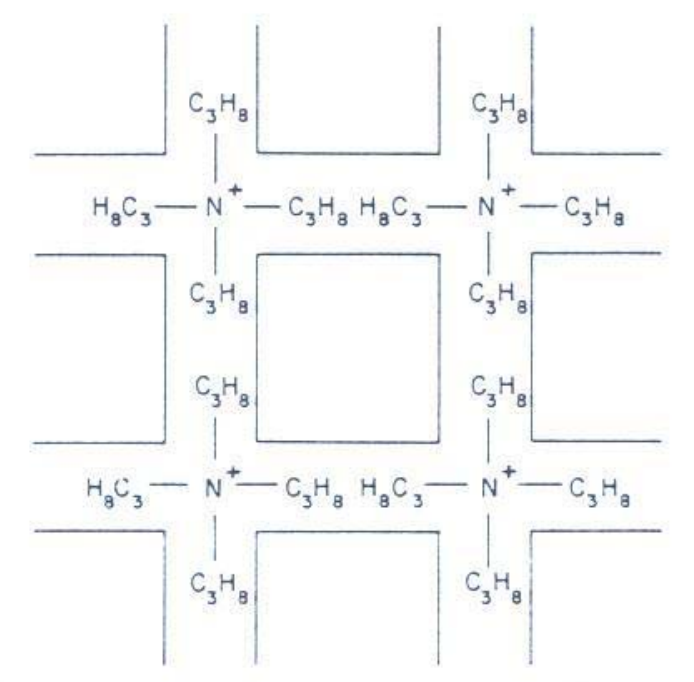

Figura 13 - A orientação do TPA nos canais da ZSM-5 (Dyer., 1988).

Neste processo as moléculas de TPA ficam fechadas na interseção dos canais com os hidrocarbonetos $\mathrm{C}_{3} \mathrm{H}_{8}$ se estendendo pelos mesmos (Lai et al.,2000). Como conseqüência após a síntese é necessária a calcinação pra a remoção do cátion.

O campo de cristalização da ZSM- 5 se torna muito estreito sem o uso de modelador. Por exemplo, apesar de não ser necessário a adição de alumínio na formação da ZSM-5 com modelador, a cristalização da mesma sem o modelador é limitada a uma estreita faixa de concentração de alumínio 
com a relação $\mathrm{SiO}_{2} / \mathrm{Al}_{2} \mathrm{O}_{3}$ geralmente na faixa de 40-180 (Lai et al.,2000). Alternativamente, a cristalização da ZSM-5 pode ser facilitada por aditivos, usualmente álcoois, cetonas e aminas, que tem diversas funções como agentes co-modeladores, preenchimento de vazios, estabilizadores do cristal e modificadores da química do gel (Iwamoto et al.,1991). Para misturas reacionais sem modelador com a relação $\mathrm{SiO}_{2} / \mathrm{Al}_{2} \mathrm{O}_{3}$ menor que 40 a fase mordenita é obtida (Lechert., 2001).

O envelhecimento da mistura reacional utilizada na síntese da ZSM5 acarreta uma diminuição dos cristais formados devido ao maior número de núcleos formados. Paralelamente há um enriquecimento do teor de alumínio na superfície dos cristais indicando que é o silício responsável pela formação dos núcleos (Carvalho et al.,1992). Outros fatores que acarretam a diminuição do tamanho de partícula final e o aumento da relação molar $\mathrm{SiO}_{2} / \mathrm{Al}_{2} \mathrm{O}_{3}$ e $\mathrm{OH} / \mathrm{SiO}_{2}$ e o decréscimo da relação $\mathrm{H}_{2} \mathrm{O} / \mathrm{SiO}_{2}$ na mistura reacional (Van Grieken et al., 2000).

A ZSM-5 é usada como catalisador no desproporcionamento do tolueno (um sub-produto do refino de petróleo) para formar benzeno e paraxileno, ambos são produtos de maior valor (Lesley \& Moore.,1992; Munhoz \& Rodrigues., 1992). A seletividade da reação na ZSM-5 ocorre devido e diferença da taxa de difusão dos diferentes isômeros através do canal. A taxa de difusão do para-xileno é aproximadamente 1000 vezes maior do que os outro dois isômeros.

A ZSM-5 é também o catalisador usado na conversão do metanol em hidrocarbonetos maiores. Esta pesquisa recebeu um grande estímulo no final dos anos 70 quando o óleo estava com baixa oferta e aumento dos preços, um cenário semelhante ao atual.

Passaram-se 18 anos entre a descoberta da ZSM-5 em 1965 e o seu primeiro uso comercial em uma unidade de craqueamento em 1983. (Degnan et al., 2000).

\subsection{Wolastonita}

A wolastonita, nomeada devido a W.H. Wollaston um mineralogista e químico inglês, é um metasilicato de cálcio tendo a formula química $\mathrm{CaSiO}_{3}$. Apesar de ser o único mineral natural acicular não metálico, tem uma história 
curta na indústria. Esta acicularidade é a principal razão de sua ascendência no final da década de 70 e 80 , como substituto do amianto e fibra de vidro.

A wolastonita é um material polimórfico e tem a composição teórica de $48,3 \%$ de óxido de cálcio e $51,7 \%$ de dióxido de silício mas pode conter impurezas como Al, $\mathrm{Fe}, \mathrm{Mg}, \mathrm{Mn}, \mathrm{K}$ e Na. Seu ponto de fusão é $1540^{\circ} \mathrm{C}$.

O mineral pode ser formado na natureza de várias formas, entretanto para jazidas comerciais é em geral aceito que existem duas possibilidades de formação. As duas envolvem metamorfismo (calor e pressão) do calcário. A sílica (quartzo) e o calcário reagem para formar a wolastonita, isto ocorre normalmente através de contato metamórfico como resultado de atividade ígnea intrusiva. A wolastonita pode se formar também pela passagem de soluções hidrotérmicas com alto teor de sílica através de leitos de calcário em um processo chamado metasomatismo.

O mineral é usualmente branco, mas pode ser cinza, marrom ou vermelho de acordo com as impurezas. Ele é quimicamente inerte, mas pode ser decomposto com ácido clorídrico concentrado.

Experimentos objetivando a síntese da wolastonita começaram com grande impulso em meados dos anos 70 . Haviam duas razões para isto; de um lado problemas de variação de qualidade da wolastonita natural, e de outro lado o aumento da importância de processos tecnológicos com economia de energia.

É aceito que o mineral wolastonita existe em três tipos cristalinos diferentes (Bedelean et al.,2000):

$1 \mathrm{~A}$ - wolastonita, triclínica $\left(\alpha-\mathrm{CaSiO}_{3}\right)$. Com os parâmetros de célula: a $=7,94 \hat{A}, b=7,32 \AA \hat{,}, c=7,07 \AA \hat{;} ; \alpha=90^{\circ} 02^{\prime}, \beta=95^{\circ} 22^{\prime}, \gamma=103^{\circ} 20^{\prime}$. Transformação a baixa temperatura, forma cristais prismáticos aciculares. Embora tenha forte clivagem nos planos $\{100\}$ e $\{001\}$ à $84^{\circ}$, similar aos piroxênios, ela tem também forte clivagem no plano $\{201\}$. Este efeito de ter três planos de clivagem paralela ao eixo cristalográfico $b$ resulta na quebra das partículas de forma acicular (igual agulha). A variação da acicularidade parece estar relacionada ao grau de desenvolvimento da ruptura do plano $\{010\}$, se é bem desenvolvido as agulhas tendem a quebrar no plano perpendicular ao comprimento com maior facilidade, tornando-se mais curta com a moagem. 
$2 \mathrm{M}$ - Parawolastonita, monoclínica $\left(\beta-\mathrm{CaSiO}_{3}\right)$. Com os parâmetros de célula: $a=5,42 \hat{A}, b=7,32 \hat{A}, c=7,07 \hat{A} ; \alpha=90^{\circ}, \beta=95^{\circ} 24^{\prime}$. Transformação $a$ baixa temperatura mas raramente ocorre na natureza, tem um habito prismático.

$7 \mathrm{M}$ - Pseudowolastonita, triclínica $\left(\mathrm{CaSiO}_{3}\right)$. Com os parâmetros de célula: $a=6,90 \AA \hat{,} b=11,78 \AA \hat{,}, c=19,65 \AA \hat{\AA} ; \alpha=90^{\circ}, \beta=90^{\circ} 48^{\prime}, y=119^{\circ} 18^{\prime}$. Transformação a alta temperatura, pseudo-ortorrômbica, tem uma estrutura caracterizada por prismas curtos ou fibras.

Enquanto as formas em baixa temperatura formam silicatos em cadeia, na fase polimorfica de alta temperatura os tetraedros $\left(\mathrm{SiO}_{4}\right)^{4-}$ formam anéis de três unidades $\left(\mathrm{Si}_{3} \mathrm{O}_{9}\right)^{6-}$, como conseqüência está fase pertence a família dos ciclosilicatos.

O tipo $1 \mathrm{~A}$ é a forma predominante sendo as outras duas muito raras na natureza.

A wolastonita de baixa temperatura é construída em cadeias de tetraedros $\mathrm{SiO}_{4}$ e camadas de octaedros $\mathrm{CaO}_{6}$ que dividem as arestas (Figura 14), uma estrutura de duas redes quase isoladas: Si-O de uma dimensão e a CaO de duas dimensões (Mihailova et al.,1995).

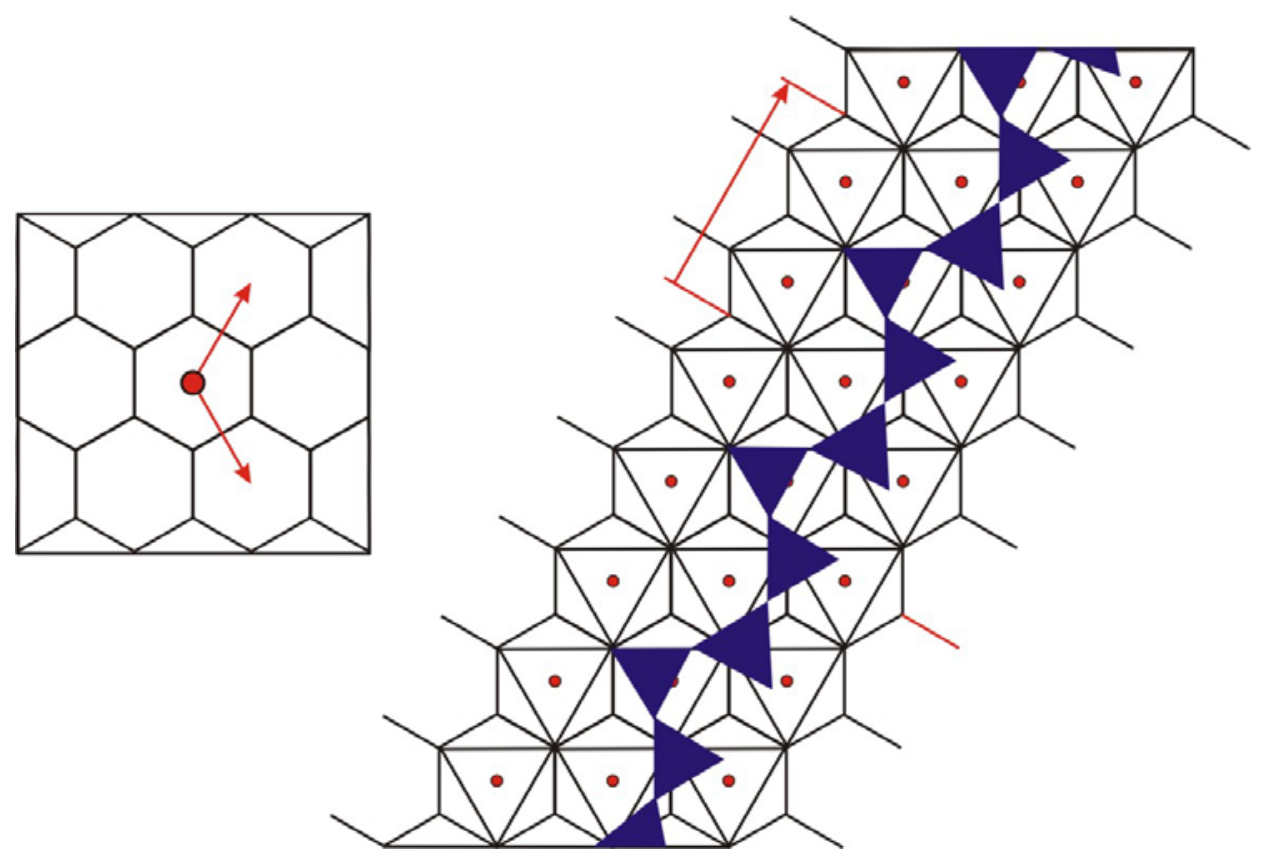

Figura 14 - A estrutura da wolastonita em cadeia. Triângulos pretos representam o tetraedro $\mathrm{SiO}_{4}$, enquanto que os poliedros representam o octaedro $\mathrm{CaO}_{6}$. A figura do quadrado mostra os vetores de translação no qual o octaedro $\mathrm{Ca}-\mathrm{O}$ é polimerizado(Mihailova et al.,1995). 
$\mathrm{Na}$ mineralogia do minério de wolastonita o fator determinante na avaliação da prospecção é a habilidade em produzir concentrados de alta pureza (Bauer et al.,1997). O ideal no sistema de processamento do minério é a obtenção de um concentrado de 97 a 99\% de pureza. Os depósitos de wolastonita geralmente contêm granada (silicato de cálcio e ferro ou alumínio) e diopsita (silicato de cálcio e magnésio). Os dois minerais são fracamente magnéticos e podem ser removidos da wolastonita com separadores magnéticos de alta intensidade.

A wolastonita também existe associada com grandes quantidades de carbonato de cálcio (calcita). Para algumas aplicações, como plásticos, o carbonato de cálcio e feldspatos devem ser removidos por flotação em espuma.

O metassilicato de cálcio sintético tem sido produzido comercialmente pelo EUA, Dinamarca, Itália e Alemanha. Os compostos sintéticos, diferentemente do natural, têm alta absortividade e não possuem a morfologia acicular. Atualmente os usos potenciais dos metassilicatos de cálcio sintéticos são os mesmos que a wolastonita natural. Em países em que a wolastonita é abundante e pode ser produzida com baixo custo, ela é preferida em detrimento da sintética. O preço da sintética equivale a duas vezes a wolastonita natural.

O metassilicato de cálcio comercial é feito atualmente com areia e carbonato de cálcio que são misturados com pequenas quantidades de dolomita que age como fundente. A pasta fluida é aquecida em um forno a $1560^{\circ} \mathrm{C}$ que forma uma pasta viscosa que é então resfriada com água. Quando solidificado o material é moído e peneirado e então reaquecido em um segundo forno à $1250^{\circ} \mathrm{C}$ para permitir a cristalização. O produto final tem $50 \%$ de wolastonita, $50 \%$ de gelenita $\left(\mathrm{Ca}_{2} \mathrm{Al}_{2} \mathrm{SiO}_{7}\right)$ e aquermanita $\left(\mathrm{MgCa}_{2} \mathrm{Si}_{2} \mathrm{O}_{7}\right)$ e é usado em superfície de estradas, telhas, pisos e feltro para forro (Bauer et al.,1997).

Um outro processo é o uso da escória fundida na produção do fósforo (Strassen \& Rauschenfels.,1979). A fluorapatita é reduzida pelo carbono com sílica na equação seguinte:

$$
3 \mathrm{Ca}_{3}\left(\mathrm{PO}_{4}\right)_{2} \cdot \mathrm{CaF}_{2}+15 \mathrm{C}+9 \mathrm{SiO}_{2} \rightarrow 6 \mathrm{P} \uparrow+15 \mathrm{CO} \uparrow+9 \mathrm{CaSiO}_{3}+3 \mathrm{CaF}_{2} .
$$

O fósforo e o monóxido de carbono são volatilizados. Os componentes remanescentes são coletados na escória. A escória fundida é temperada com 
água resultando em uma areia vítrea. Após a remoção de impurezas e adição de substâncias modificadoras, esta é queimada a $1200^{\circ} \mathrm{C}$ em atmosfera oxidante, em que a cor final se torna branca.

A produção mundial de wolastonita foi cerca de 145.000 toneladas em 1986 e dobrou em 1993, aumentou para 500.000 t em 2000 e 600.000 t em 2002. Nos EUA os preços em dólares são: 0,11 a US\$ 0,22/kg grau moído (45 a $75 \mu \mathrm{m}$ );

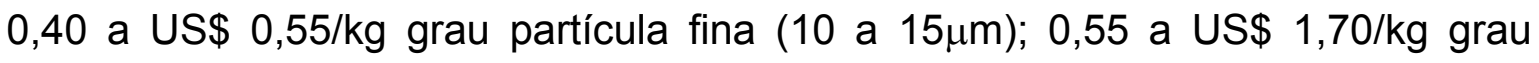
quimicamente modificado (modificado superficialmente para melhorar o desempenho em sistemas baseados em resinas). A produção mundial foi encabeçada pela China com cerca de 300.000 t/ano, seguido dos Estados Unidos com 150.000 t/ano, Índia com 100.000 t/ano, México com 40.000 t/ano e Finlândia com 20.000 t/ano. Pequenas produções são feitas em Marrocos, Namíbia, Coréia do Norte, Paquistão e Turquia.

Em 1999, a indústria de plásticos foi responsável por $37 \%$ do consumo americano, seguido por cerâmica (28\%), metalurgia (10\%), tintas (10\%), produtos de fricção (9\%) e outros (6\%) (Virta.,2002).

O caráter acicular da wolastonita moída é responsável por uma importante aplicação que é de carga de reforço. A grau de acicularidade é medido pela razão de aparência, que é a divisão do comprimento pela largura das agulhas. É importante notar que a razão de aparência do mineral moído não é a mesma que a dos cristais na rocha, pode variar de 2:1 para 20:1. As técnicas e equipamentos específicos de moagem usados pelos produtores de wolastonita de alta razão de aparência é guardado em segredo.

O tamanho ideal de partícula da wolastonita é determinado primeiramente pela aplicação. Em geral partículas grossas são consideradas indesejadas porque podem prejudicar o reforço mecânico, e também segregam e decantam rapidamente prejudicando o processo e levando a uma maior abrasão com danos ao acabamento superficial. Por outro lado, uma quantidade excessiva de finos pode levar a um reforço mecânico ineficaz, alto consumo de resina como enchimento e problemas com o manuseio do material.

Outras características importantes da wolastonita para uso industrial são:

- Alto brilho e brancura.

- Baixa quantidade de voláteis. 
- Baixa contração e ponto de fusão.

- Alcalinidade $(\mathrm{pH}=9,9)$.

- Macieza (Dureza Mohs 5,0-5,5) para não desgastar equipamentos de aço na moldagem.

- Não tóxica.

Os principais usos da wolastonita são:

Substituição do asbesto: Uso em pranchas de construção exteriores e interiores, telhas, isolantes. A wolastonita é usada nestes produtos principalmente como substituto do amianto. O consumo mundial de wolastonita com alta razão de aparência tem esta aplicação como maior mercado. Ela proporciona resistência, estabilidade térmica, baixa densidade e uma natureza coesiva. Outro uso é na indústria de produtos de fricção, como revestimento de freios e embreagens. Parte desta wolastonita usada é tratada superficialmente.

Cerâmicas: É o uso original da wolastonita e continua sendo o maior consumo por tonelada. São aqui as características químicas mais importantes que as físicas, como baixa quantidade de Fe e voláteis. As vantagens do uso da wolastonita em cerâmicas são duas. Ela melhora as propriedades mecânicas da cerâmica e reduz falhas por empenamento e fratura dos matérias cerâmicos que são rapidamente aquecidos. A wolastonita se difunde rapidamente com a sílica e alumina a baixas temperaturas, reduzindo a expansão térmica e minimizando fraturas no encolhimento.

Metalurgia: Usado como agente de fundição na siderurgia para manter o metal em estado fundido durante o refino. Esta prática minimiza defeitos superficiais, evita re-oxidação do aço, lubrifica as paredes do molde e absorve inclusões não-metálicas. A wolastonita é usada também em formulações de soldas, onde ela melhora as características da queima e inibe faíscas durante a soldagem. Consome-se mundialmente wolastonita de baixa qualidade, para este fim.

Tintas e revestimentos: A wolastonita é usada extensivamente em tintas e revestimentos por mais de 45 anos. A wolastonita grau moído (10 $\mu \mathrm{m})$, de todas as razões de aparência, é usada em tintas onde ela proporciona reforço, dureza do filme, abrasividade, redução do brilho, retenção da cor, baixa absorção de óleo e baixa demanda de água e ligante. Em tintas látex à base de água a wolastonita melhora a estabilidade da tinta na estocagem. Em tintas de polivinil 
acetato (PVA) ela ajuda a neutralizar a acidez. Suas características químicas também melhoram a resistência à corrosão em superfícies metálicas exteriores, como pontes.

Plásticos e borracha: Todos os graus de wolastonita são usados na indústria do plástico. É o setor de maior venda de wolastonita por faturamento. Em geral ela é usada porque tem baixa absorção de água, boa estabilidade térmica, baixa demanda de resina, pureza química e propriedades de reforço, ela aumenta a resistência e rigidez dos componentes de plástico.

A wolastonita tratada superficialmente usada como enchimento na indústria de plástico desempenha duas funções: ela permite que a resina plástica molhe a superfície do mineral permitindo uma melhor dispersão das partículas e assim reduzindo a viscosidade (reduz o tempo do ciclo de moldagem) da mistura para uma melhor condição de moldagem; também aumenta a resistência da união entre o enchimento e o plástico melhorando a rigidez do material compósito. Uma variedade de compostos químicos são usados para tratar superficialmente a wolastonita, incluindo ácidos, organosilanos, estearatos, zircoaluminatos e titanatos.

As maiores aplicações têm sido na indústria automobilística principalmente em plásticos termocurados incluindo compostos fenólicos, epóxi, poliuretano, poliuréia, poliéster BMC; termoplásticos como polipropileno, nylon, poliéster, policarbonato e outros plásticos de engenharia e ligas.

A indústria de plástico mundial é o principal mercado para a wolastonita em termos de valores, e o de maior crescimento da demanda da wolastonita superficialmente tratada.

A wolastonita também é usada como condicionador de solos e aditivo em fertilizantes por sua reatividade em condições ácidas. Em oposição à cal e a calcita, ela oferece uma proteção de longo tempo contra a acidificação do solo. Em alguns países, a wolastonita é usada como portador inerte para pesticidas e inseticida.

\subsubsection{Sistema CaO- $\mathrm{SiO}_{2}-\mathrm{H}_{2} \mathrm{O}$}

Silicatos de cálcio hidratados são preparados pela reação de sílica e óxido de cálcio sob condições hidrotermais (Tsunematsu et al.,2004). A hidratação do cimento Portland a temperatura ambiente produz mais que $50 \%$ de 
silicato de cálcio hidratado (CSH). Este produto quase amorfo pode ter uma relação $\mathrm{Ca} / \mathrm{Si}$ variando de 0,8 a 2,0. O entendimento do sistema $\mathrm{CaO}-\mathrm{SiO}_{2}-\mathrm{H}_{2} \mathrm{O}$ incluindo as fases estáveis e metaestáveis é essencial na interpretação da mineralogia e propriedades dos produtos sólidos (Glasser \& Hong.,2003).

A solubilidade do $\mathrm{Ca}(\mathrm{OH})_{2}$ é anômala, isto é, decresce com o aumento da temperatura, enquanto a solubilidade da sílica é normal e aumenta com a temperatura (Ibañes \& Sandoval.,1998).

O gel CSH é termodinamicamente instável em todas as temperaturas. Em sua ocorrência natural ele pode estar intimamente associado com fases cristalinas. Sob condições hidrotermais, o gel CSH de composição apropriada pode se converter rapidamente em fases cristalinas. Por exemplo, cimentos comerciais autoclavados baseados no sistema $\mathrm{CSH}$ freqüentemente produzem mais que $50 \%$ de fases como a tobermorita e xonolita entre $160-190^{\circ} \mathrm{C}$.

As relações das fases no sistema $\mathrm{CaO}-\mathrm{SiO}_{2}-\mathrm{H}_{2} \mathrm{O}$ ainda não são bem definidas, embora condições de síntese de várias das fases constituintes seja bem conhecido. Versões correntes do diagramas de fase $\mathrm{CaO}-\mathrm{SiO}_{2}-\mathrm{H}_{2} \mathrm{O}$ à pressão de vapor saturada e temperaturas entre $85-200^{\circ} \mathrm{C}$ são baseados em dados de qualidade variável (Tabela 3). Eles utilizam em parte dados de critérios experimentais para um equilíbrio de fase mas em parte incluem dados que refletem o modo de ocorrência das fases cristalinas. Além disso, ao menos uma fase, jenita, que é certamente estável a baixa pressão (1 bar) não está em concordância com o diagrama de fase. A descoberta que muitas reações de formação e decomposição no sistema $\mathrm{CaO}-\mathrm{SiO}_{2}-\mathrm{H}_{2} \mathrm{O}$ ocorrem de modo reversível, junto com novos dados na composição e estabilidade da jenita, tem permitido diagramas de fase com maior precisão que foi possível até agora.

Muitas fases $\mathrm{CSH}$ ocorrem na natureza ou tem sido relatadas na literatura mas não aparecem em estudos experimentais. Isto pode ser tanto por não estar na faixa de temperatura como na composição estudada ou também pode estar estabilizada pela pressão. Um exemplo é a rustumita, $\mathrm{Ca}_{4}[\mathrm{OH}] \mathrm{Si}_{2} \mathrm{O}_{7}$, ela é provavelmente estável $\mathrm{a}<200^{\circ} \mathrm{C}$, mas somente a altas pressões.

A presença de compostos cristalinos estáveis somente a temperaturas moderadamente elevadas como fosagita, hilebrandita, dicálcio silicato hidratado e jafeita são dignos de nota. Pela visão termodinâmica, estes compostos se comportam como o $\mathrm{Ca}_{3} \mathrm{SiO}_{5}$ no sistema $\mathrm{CaO}-\mathrm{SiO}_{2}$ anidro. $\mathrm{O} \mathrm{Ca}_{3} \mathrm{SiO}_{5}$ tem a 
temperatura mínima da estabilidade termodinâmica a $1275^{\circ} \mathrm{C}$, abaixo disto ele se decompõe em equilíbrio a $\mathrm{CaO}$ e $\mathrm{Ca}_{2} \mathrm{SiO}_{4}$. A razão desta incrível estabilidade a altas temperaturas é atribuída a sua não usual estrutura cristalina, um em cada cinco oxigênios está ligado somente ao cálcio, e a estrutura como um todo tem uma não ideal soma de valências nas ligações eletrostáticas. Isto então estabiliza a altas temperaturas por contribuições térmicas de entropia.

Tabela 3 - Fases formadas no sistema $\mathrm{CaO}-\mathrm{SiO}_{2}-\mathrm{H}_{2} \mathrm{O}$ até $200^{\circ} \mathrm{C}($ Glasser \& Hong.,2003).

Fase

Fórmula

Relação

$\begin{array}{ccc}\text { Fase } & \text { Fórmula } & \begin{array}{c}\text { Relação } \\ \text { Ca/Si }\end{array} \\ \text { Tobermorita } & \mathrm{Ca}_{5}\left(\mathrm{Si}_{6} \mathrm{O}_{16}\right)(\mathrm{OH})_{2} \cdot 4 \mathrm{H}_{2} \mathrm{O} & 0,83 \\ \text { Xonolita } & \mathrm{Ca}_{6}\left(\mathrm{Si}_{6} \mathrm{O}_{17}\right)(\mathrm{OH})_{2} & 1,0 \\ \text { Fosagita } & \mathrm{Ca}_{4}\left(\mathrm{Si}_{3} \mathrm{O}_{9}\right)(\mathrm{OH})_{2} & 1,33 \\ \text { Jenita } & \mathrm{Ca}_{9} \mathrm{H}_{2}\left(\mathrm{Si}_{6} \mathrm{O}_{18}\right)(\mathrm{OH})_{8} \cdot 6 \mathrm{H}_{2} \mathrm{O} & 1,45 \\ \text { Afilita } & \mathrm{Ca}_{3}\left(\mathrm{SiO}_{3}\right)_{2}(\mathrm{OH})_{2} \cdot 2 \mathrm{H}_{2} \mathrm{O} & 1,5 \\ \text { Hilebrandita } & \mathrm{Ca}_{2} \mathrm{SiO}_{3}(\mathrm{OH})_{2} & 2,0 \\ \text { a-C } & \mathrm{Ca}_{2}\left(\mathrm{HSiO}_{4}\right) \mathrm{OH} & 2,0 \\ \text { Tri-cálcio } & \mathrm{Ca}_{6} \mathrm{Si}_{2} \mathrm{O}_{7}(\mathrm{OH})_{6} & 3,0 \\ \text { silicato } & & \end{array}$

A tobermorita se decompõe numa fase amorfa em tratamento térmico a $800^{\circ} \mathrm{C}$ e sofre completamente uma transição de fase à $\beta$-wolastonita a $1000^{\circ} \mathrm{C}$ (Tsunematsu et al.,2004). A xonolita passa por uma transformação de fase à $\beta$ wolastonita a $800^{\circ} \mathrm{C}$ sem transição por fase amorfa. A decomposição da tobermorita se da pela seguinte equação:

$\mathrm{Ca}_{5}(\mathrm{OH})_{2} \mathrm{Si}_{6} \mathrm{O}_{16} 4 \mathrm{H}_{2} \mathrm{O} \rightarrow 5 \mathrm{CaSiO}_{3}+\mathrm{SiO}_{2}+5 \mathrm{H}_{2} \mathrm{O}$

E a decomposição da xonolita é:

$\mathrm{Ca}_{6}\left(\mathrm{Si}_{6} \mathrm{O}_{17}\right)(\mathrm{OH})_{2} \rightarrow 6 \mathrm{CaSiO}_{3}+\mathrm{H}_{2} \mathrm{O}$

Em que não há a formação da sílica. 
Estudos feitos por Mi \& Hanada(1997) para a formação de tobermorita por moagem a úmido do hidróxido de cálcio e sílica gel em moinho planetário mostraram que apesar da formação da fase desejada o sistema hidrotermal resulta em tobermorita com maior cristalinidade.

Em estudo feitos por Alizadeh \& Marghussian(2000) no sistema $\mathrm{SiO}_{2}-$ $\mathrm{CaO}-\mathrm{MgO}$ para formação de cerâmicas vítreas, foi obtida wolastonita entre outras fases apenas por processo pirometalúrgico à $1400^{\circ} \mathrm{C}$. Atalay et al(2001) obteve wolastonita no sistema $\mathrm{Fe}_{2} \mathrm{O}_{3}-\mathrm{CaO}-\mathrm{SiO}_{2}$.

\subsubsection{Síntese da wolastonita}

A síntese industrial da wolastonita por reação em fase sólida foi precedida por um numero de investigações teóricas feitas por Hedwall e Jander (Kotsis et al.,1989). Estas investigações referiam-se a problemas como:

- Composição química dos materiais de partida.

- Tamanho de partícula dos materiais de partida.

- Relação molar $\mathrm{CaO} / \mathrm{SiO}_{2}$.

- Efeito de mineralizadores na temperatura de formação da wolastonita.

- Cinética de formação.

- Possibilidade de síntese de uma dada modificação da wolastonita.

As matérias primas da síntese da wolastonita são as seguintes: $\mathrm{CaO}$, $\mathrm{Ca}(\mathrm{OH})_{2}, \mathrm{CaCO}_{3}, \mathrm{CaSO}_{4}$, calcário com sílica, areia de quartzo e escória da produção de fósforo. Quase todas as publicações mencionam o tamanho de partícula das matérias primas na determinação da taxa de reação (Withiam et al., 2003). Estudos comprovam uma significante maior conversão na formação da wolastonita aumentando a superfície específica da areia de quartzo (Kotsis et al., 1989).

Em relação a estequiometria da reação, é proposto na literatura a relação molar $\mathrm{CaO} / \mathrm{SiO}_{2}$ variando de 0,7-1,2 (Ohnemuller \& Solf.,1976). Na redução da temperatura de formação, mineralizadores são adicionados como fluorita e sulfato de amônia. A temperatura ótima de calcinação varia entre 1045$1480^{\circ} \mathrm{C}$. Pode-se ver no diagrama de fase do sistema $\mathrm{CaO}-\mathrm{SiO}_{2}$ (Figura 15) que a $\beta$-wolastonita se transforma para $\alpha$-wolastonita a $1125^{\circ} \mathrm{C}$.

Ibañes \& Sandoval(1998) estudou em detalhes a rota hidrotermal para sintetizar wolastonita. A rota hidrotermal tem tido sucesso em sintetizar 
hidrossilicatos de cálcio. A wolastonita é sintetizada por tratamento térmico destes hidrossilicatos a baixa temperatura, isto é, $1000^{\circ} \mathrm{C}$. A água como líquido ou vapor age de duas formas: como meio de transmissão de pressão; e aonde a reação ocorre. Desde que alguns ou todos os reagentes são parcialmente solúveis em água sob pressão. Sob estas condições as reações podem ocorrer, que na falta de água, ocorreriam somente sob altas temperaturas.

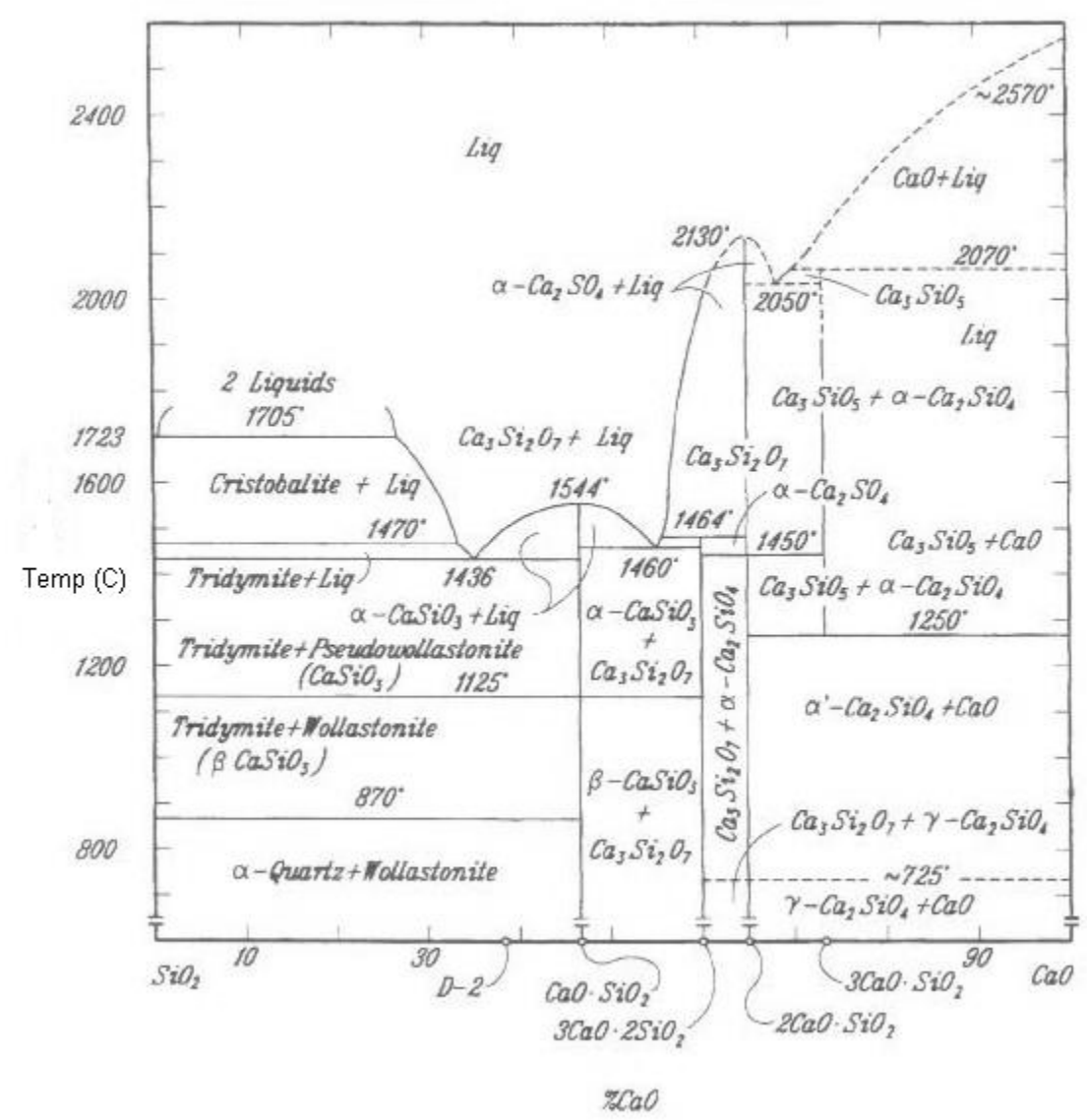

Figura 15 - Diagrama de fase do sistema CaO-SiO ${ }_{2}$ (Kotsis et al.,1989). 


\section{PARTE EXPERIMENTAL}

O trabalho e seus resultados estão fundamentados conforme o diagrama de blocos a seguir:

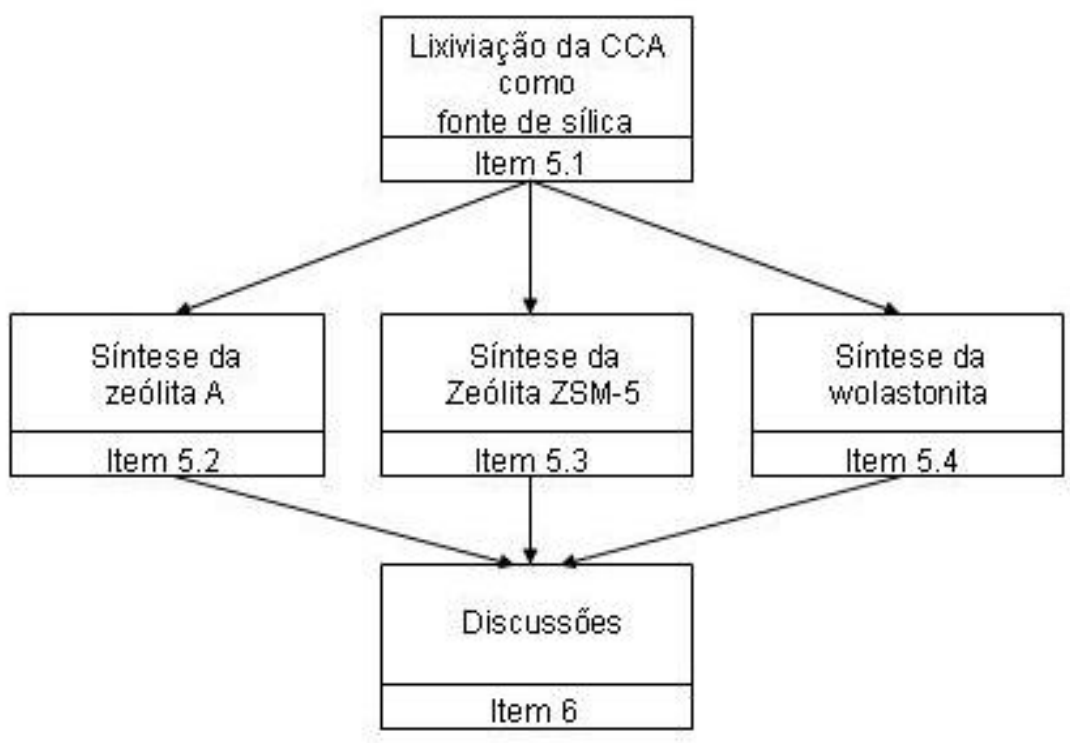

\subsection{Extração da sílica}

No fluxograma da Figura 16 está o processo desenvolvido na lixiviação da sílica na CCA.

Inicialmente, foi usada uma CCA queimada à baixa temperatura $\left(700^{\circ} \mathrm{C}\right)$ originária de Santa Catarina, e depois foi testada a CCA queimada à alta temperatura $\left(1100^{\circ} \mathrm{C}\right)$ originária de Uruguaiana-RS. A análise química foi realizada para o teor de sílica da CCA, cujo dado é importante na relação Si/Na usada na extração e no cálculo de eficiência. As amostras de CCA foram caracterizadas utilizando difração de raios $X$ com o objetivo de identificar as fases de sílica presentes.

A sílica foi extraída da CCA na lixiviação com hidróxido de sódio (1M), sob agitação intensa, à $90^{\circ} \mathrm{C}$. É preparado $1 \mathrm{~L}$ de solução antes da adição da CCA. As relações em massa Si/Na testadas foram 1,0; 2,0; 2,5; 3,0; 3,5 e 4,0. A solução foi agitada por 1 hora até lixiviar à sílica e produzir a solução de silicato de sódio. A solução foi filtrada, a parte retida lavada à quente (repolpada) e 
novamente filtrada. O resíduo foi seco à $110^{\circ} \mathrm{C}$ por 12 horas e, em seguida, pesado.

A solução de silicato de sódio foi analisada quantitativamente por ICPOES.

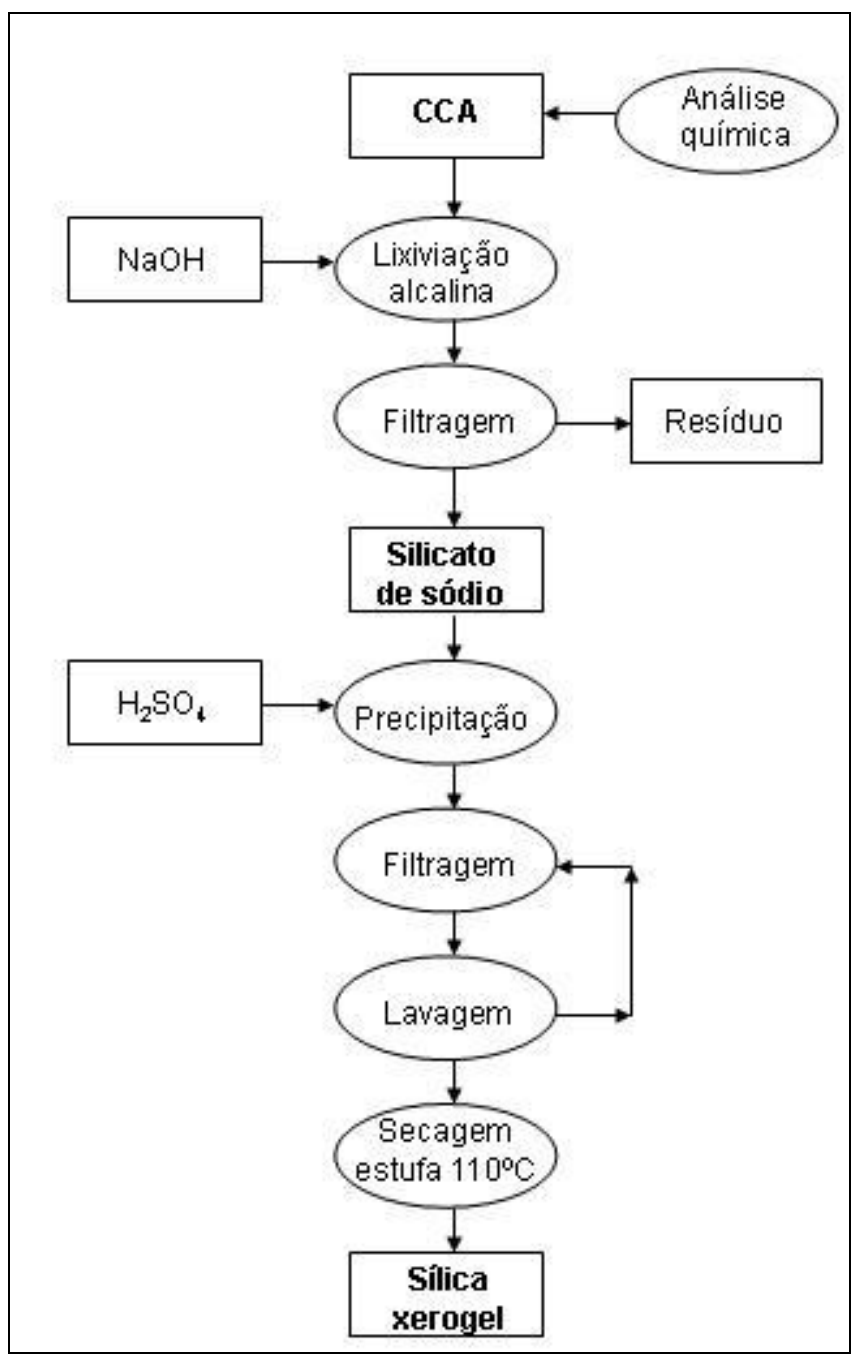

Figura 16 - Fluxograma da seqüência de extração da sílica na CCA.

A precipitação da sílica foi realizada por gotejamento de ácido sulfúrico (P.A.) com pH controlado. Uma vez precitada a sílica gel é lavada sucessivamente até $\mathrm{pH}=8$. Depois é seca em estufa por 24 horas e $110^{\circ} \mathrm{C}$ para a formação do xerogel.

Em seguida, a área superficial específica foi obtida pelas isotermas de nitrogênio.

O processo de gotejamento do ácido foi realizado utilizando uma pipeta e agitação. Em algumas etapas na síntese da wolastonita a adição de ácido foi 
realizada até o $\mathrm{pH}$ atingir o valor de 6,5 com a posterior filtragem e lavagem da sílica sol-gel.

Um estudo de comparação de densidades foi realizado, para testar se o cálculo de sílica na solução de silicato, através da diferença de massa da CCA antes e após a lixiviação, é realmente confiável e relacionar a densidade da solução de silicato com sua concentração, sem o uso de análise química. A não necessidade de sempre analisar quantitativamente as soluções de silicato de sódio tornam os experimentos muito mais ágeis.

Primeiro, a densidade da solução de tri-silicato de sódio comercial $\left(63 \% \mathrm{SiO}_{2}, 18,5 \% \mathrm{Na}_{2} \mathrm{O}, 18,5 \% \mathrm{H}_{2} \mathrm{O}\right)$ foi medida em várias concentrações, diluindo este em $1 \mathrm{~L}$ de água destilada. O cálculo da densidade foi realizado com o uso de uma proveta graduada até $1000 \mathrm{~mL}$ e balança analítica. A composição do tri-silicato possibilitou a obtenção de sólidos totais e sílica total. Depois calculouse as diferentes densidades de silicatos de sódio obtidos da CCA em diferentes concentrações de CCA usadas. O cálculo de sílica lixiviada foi realizado pela diferença de massa da CCA, enquanto, para o cálculo de sólidos totais foi adicionando a quantidade de soda cáustica que foi usada. A lixiviação da pequena quantidade de fase orgânica foi desprezada.

Com os dados obtidos pode-se comparar graficamente as densidades em relação a quantidade de sílica e sólidos totais nos dois processos.

\subsection{Síntese de zeólitas}

Para a síntese das zeólitas foi projetado e construído um autoclave de aço inox 316 com volume de $800 \mathrm{~mL}$. O autoclave foi aquecido em um forno com controle de temperatura. A mistura reacional foi colocada no autoclave dentro de um béquer de teflon de $250 \mathrm{~mL}$.

Posteriormente, a síntese da zeólita $A$ foi realizada utilizando um vaso de pressão de 20L, com o objetivo de preparar uma quantidade de amostra maior para testes industriais.

\subsubsection{Zeólita A}

O fluxograma da Figura 17, mostra a rota de síntese desenvolvida para a produção da zeólita $A$. 
Este material foi sintetizado diretamente da solução de silicato de sódio extraído da CCA com a relação Si/Na de 4,0 e densidade de $1108 \mathrm{~g} / \mathrm{L}$, com sua composição descrita na Tabela 9.

Uma desvantagem de usar sais de alumínio é, após o ajuste do pH ou adição de uma solução de silicato alcalino, a formação de sais alcalinos que tem um forte efeito eletrolítico na formação do gel. Por exemplo, alguns sais podem causar a nucleação da sodalita ao invés da zeólita A. Por esta razão é vantajoso, particularmente para misturas reacionais de baixa relação $\mathrm{SiO}_{2} / \mathrm{Al}_{2} \mathrm{O}_{3}$, introduzir o alumínio na forma aniônica, ou seja, o íon aluminato $\mathrm{Al}(\mathrm{OH})_{4}^{-}$.

A solução de aluminato de sódio foi preparada com a reação de $50 \mathrm{~g}$ de alumínio metálico (papel alumínio) com hidróxido de sódio 1,75 M. A reação foi realizada em capela com boa exaustão devido ao desprendimento de gás hidrogênio.

A solução final é filtrada e guardada em recipiente fechado. É importante que a solução não fique em contato $\mathrm{com} \mathrm{CO}_{2}$, pois pode formar óxidos de alumínio hidratados. A densidade final da solução foi de $1115 \mathrm{~g} / \mathrm{L}$.

O gel foi preparado com a adição da solução de silicato de sódio sobre a de aluminato de sódio sob agitação, em diferentes relações volumétricas das duas soluções. Após a formação do gel a agitação continua de forma manual, exceto para a amostra $A 6$ que não houve agitação após a formação do gel.

$\mathrm{O}$ acerto correto da relação molar $\mathrm{SiO}_{2} / \mathrm{Al}_{2} \mathrm{O}_{3}$ para a zeólita $\mathrm{A}$, foi realizado analisando o diagrama de fase $\mathrm{Na}_{2} \mathrm{O}-\mathrm{SiO}_{2}-\mathrm{Al}_{2} \mathrm{O}_{3}$ obtido da literatura (Figura 9), em que o ideal é que esta relação esteja cerca de 2,5. 


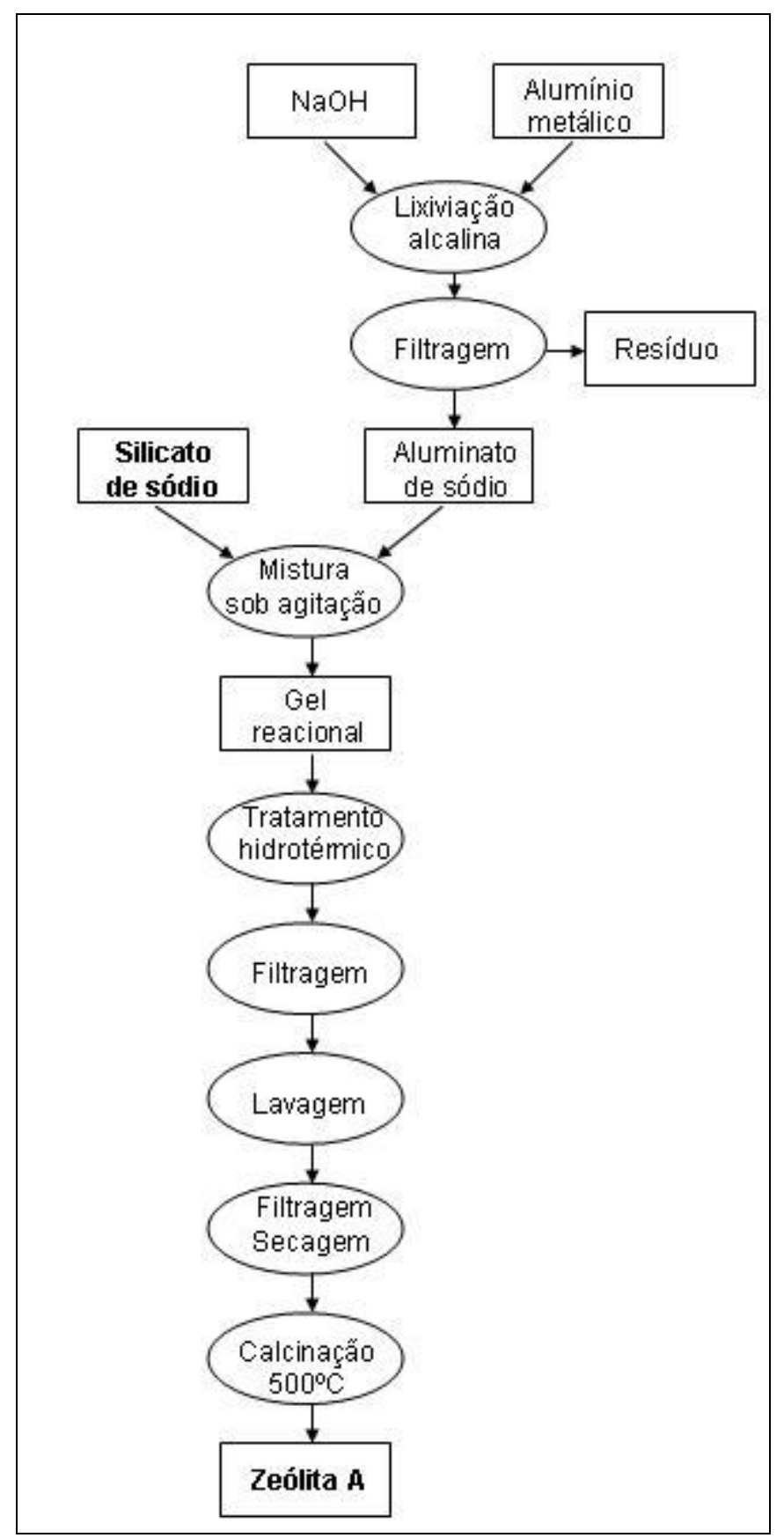

Figura 17 - Fluxograma da seqüência de síntese da zeólita A.

As relações volumétricas e condições de síntese, tempo e temperatura de cristalização, usadas nas diferentes amostras estão descritas na Tabela 4.

O gel não foi envelhecido. Contudo, esse material cristalizado em autoclave sob pressão autógena. Após a cristalização, o sólido foi filtrado e lavado, apenas uma vez, com posterior secagem em estufa a $110^{\circ} \mathrm{C}$. 
Tabela 4- Condições de síntese das amostras de zeólita A.

Amostra

Relação

$T(h)$

$T\left({ }^{\circ} \mathrm{C}\right)$

em volume

silicato/alu

minato

A1

$140 \mathrm{~mL} /$

4

100

$110 \mathrm{~mL}$

A2

$130 \mathrm{~mL} /$

4

100

$110 \mathrm{~mL}$

A3

$120 \mathrm{~mL} /$

4

100

$110 \mathrm{~mL}$

A4

$120 \mathrm{~mL} /$

12

100

$110 \mathrm{~mL}$

A5

$120 \mathrm{~mL} /$

2

100

$110 \mathrm{~mL}$

A6

$120 \mathrm{~mL} /$

4

100

$110 \mathrm{~mL}$,

sem agitar.

As fases formadas em diferentes relações Si/Al no gel, foram caracterizadas por DRX. Contudo, as análises químicas e morfológicas das amostras foram também realizadas.

Uma condição muito importante é que o copo de teflon após cada cristalização seja bem limpo, por causa do material cristalizado que adere em sua superfície, de preferência com ácido fluorídrico, para que este material residual não funcione como "semente" para uma nova cristalização.

Os testes de troca catiônica foram realizados com a amostra que melhor sintetizou a zeólita A.

O melhor processo foi sintetizado em um vaso de pressão de $20 \mathrm{~L}$, aquecido por uma camisa com passagem de vapor d'água, uma quantidade de 2 kg foi utilizada para o teste industrial como aditivo na fórmula de sabão em pó.

\subsubsection{Zeólita ZSM-5}

Para a síntese da ZSM-5 foram utilizadas 4 rotas diferentes, que estão esquematizadas no fluxograma da Figura 18. A primeira de acordo com a 
literatura, com a sílica xerogel da CCA. A segunda, diretamente com o silicato de sódio comercial, com o objetivo de reduzir etapas e obter um material mais cristalino. A terceira, já utilizando o silicato de sódio da CCA, e a quarta e última, otimizando o processo, com o silicato de sódio da CCA e sem adição de modelador (template), usando como um co-modelador (etanol) e "sementes" de ZSM-5.

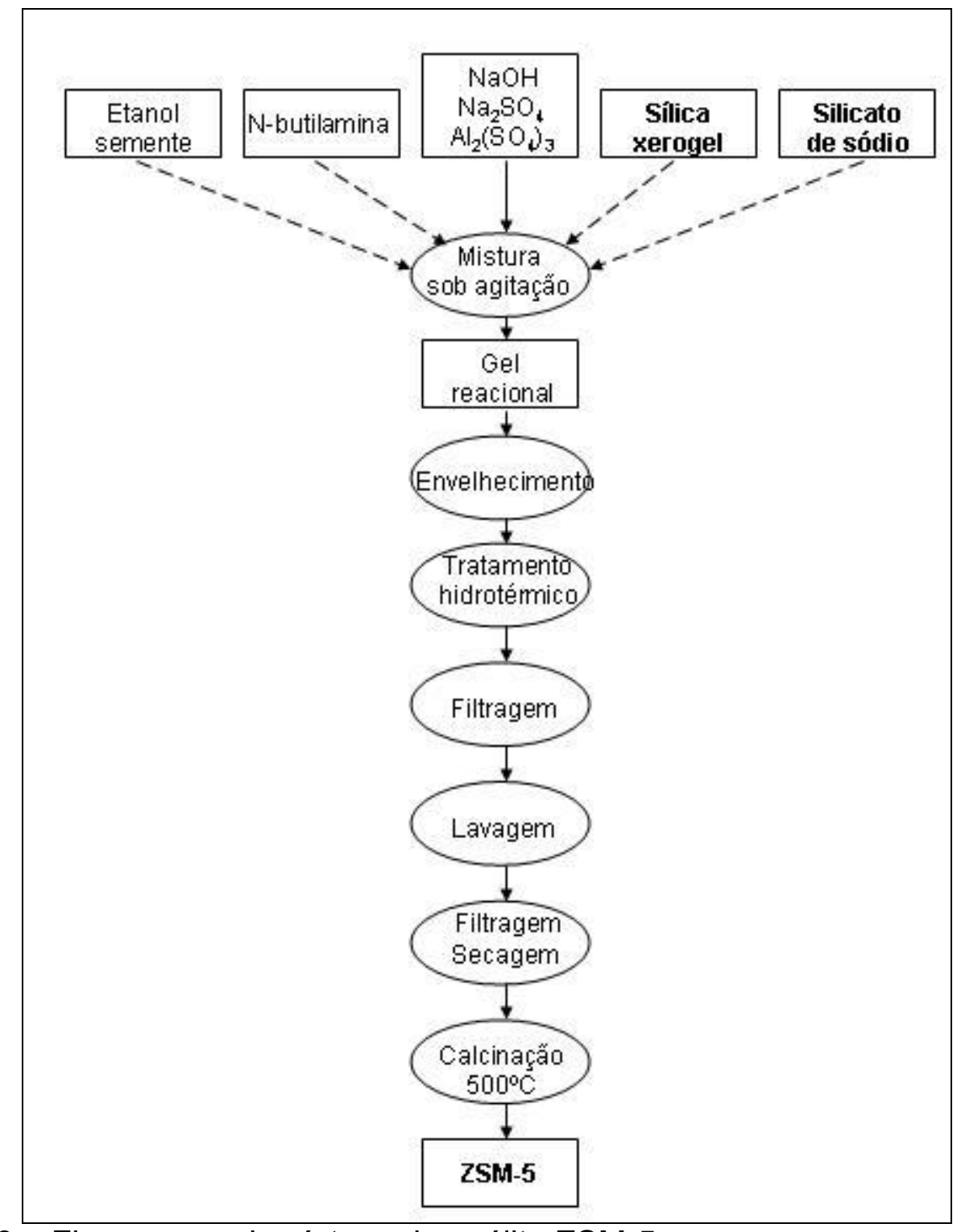

Figura 18 - Fluxograma de síntese da zeólita ZSM-5.

Sílica xerogel: A primeira tentativa, para a síntese da ZSM-5, o método utilizado foi o desenvolvido por Cardoso et al.(1995), que emprega a sílica 
dispersa na forma de xerogel, formado por partículas esferoidais com área específica entre 100 e $400 \mathrm{~m}^{2} / \mathrm{g}$. A superfície específica da sílica usada, sintetizada da CCA, foi de $260 \mathrm{~m}^{2} / \mathrm{g}$.

A síntese da ZSM-5 realizada está descrita nas etapas seguintes:

Mistura reacional preparada com os seguintes reagentes: uma solução de 4,42 $\mathrm{g}$ de sulfato de alumínio dissolvido em 79,3 $\mathrm{mL}$ de água destilada, 14,80 $\mathrm{g}$ de sulfato de sódio dissolvidos em 314,5 mL de água, 6,37 g de hidróxido de sódio em 81,2 mL de água. Sob agitação adicionou-se lentamente a solução de $\mathrm{Al}_{2}\left(\mathrm{SO}_{4}\right)_{3}$ no béquer com o $\mathrm{NaOH}$. Em seguida, foi acrescentada a solução de $\mathrm{Na}_{2} \mathrm{SO}_{4}$ e 19,43 mL de n-butilamina $\left[\mathrm{CH}_{3}\left(\mathrm{CH}_{2}\right)_{3} \mathrm{NH}_{2}\right]$. Em seguida, foi adicionado 39,89 g de sílica xerogel obtido da CCA sob agitação até a total homogeneização (visual) da mistura.

Envelhecimento. A mistura reacional foi dividida em três partes: iguais e envelhecida por 45 horas (amostra Z1), 96 horas (Z2) e 192 horas (Z3) num banho termostático fechado à $40^{\circ} \mathrm{C}$.

Cristalização. O gel foi posto em um recipiente de teflon de $250 \mathrm{~mL}$, e este no autoclave de aço inox. A cristalização foi realizada à $170^{\circ} \mathrm{C}$ por 50 horas para as três amostras.

Lavagem e Secagem. O autoclave foi resfriada em água. O conteúdo foi filtrado e lavados em água destilada até atingir o $\mathrm{pH}$ igual a 8 . A fase sólida precipitada (zeólita) foi seca em estufa $\left(110^{\circ} \mathrm{C}\right)$ por 24 horas.

Preparo da ZSM-5. A fase sólida foi calcinada em mufla sob fluxo de gás inerte (argônio analítico), com vazão de 1,2 L/h, por 4 horas a temperatura de $500^{\circ} \mathrm{C}$, para decompor a base orgânica n-butilamina nos poros. E depois, 2 horas sob fluxo de ar com a mesma vazão, para eliminar o coque que tenha se formado pela decomposição da base orgânica.

Trisilicato de Sódio P.A.: Posteriormente foram sintetizadas 4 amostras rotuladas de AZSM-5, BZSM-5, CZSM-5 e DZSM-5 com o trisilicato de sódio P.A. $\left(63,5 \%\right.$ de $\mathrm{SiO}_{2}, 18,5 \%$ de $\mathrm{Na}_{2} \mathrm{O}$ e $\left.18 \% \mathrm{H}_{2} \mathrm{O}\right)$. A composição da mistura reacional foi de 480,6 $\mathrm{mL}$ de água destilada, 15,6 g de $\mathrm{NaOH}, 3,98 \mathrm{~g}$ de $\mathrm{Al}_{2}\left(\mathrm{SO}_{4}\right)_{3} .14 \mathrm{H}_{2} \mathrm{O}, 45,44 \mathrm{~g}$ de $\mathrm{Na}_{2} \mathrm{SO}_{4}, 63,5 \mathrm{~g}$ de trisilicato de sódio e 19,56 $\mathrm{g}$ $(26,43 \mathrm{~mL})$ de n-butilamina. 
Após a homogeneização da mistura foi gotejado lentamente, com uma pipeta, ácido sulfúrico sob agitação até a formação do gel (branco opaco), a agitação continuou manualmente após a formação do gel.

As amostras A, B, C e D tiveram, respectivamente, tempos de envelhecimento de 48, 70, 118 e 168 horas e tempos de cristalização de 50 horas. As outras etapas foram iguais a primeira rota de síntese da sílica xerogel.

Trisilicato de Sódio da CCA: Nesta etapa sintetizou-se a ZSM-5 usando o silicato de sódio extraído da CCA.

O silicato foi preparado usando a relação 4:1 em solução $1 \mathrm{M}$ de $\mathrm{NaOH}$. Os resultados do silicato de sódio está na Tabela 9.

Foram usadas as relações dos reagentes na mistura reacional iguais a etapa do trisilicato de sódio comercial acima, com a diferença que a quantidade de sulfato de alumínio foi o dobro. Isto, teve como objetivo, ver a influência desta maior concentração na morfologia e composição do produto final.

O tempo de cristalização foi de 50 horas e o tempo de envelhecimento foi de 48 horas (amostra Zeo1), 70 horas (Zeo2) e 118 horas (Zeo3).

Foram feitas mais três amostras também com tempo de cristalização de 50 horas e tempos curtos de envelhecimento, de 10 horas (amostra SILZ1), 14 horas (SILZ2) e 16 horas (SILZ3).

CCA com etanol: Baseado no trabalho de Lau et al.(1989) foram realizadas tentativas de síntese da ZSM-5 em um processo de baixo custo sem o uso do padrão, foi adicionado um co-direcionador (etanol) e semente (cristais de ZSM-5).

O silicato de sódio usado foi o mesmo descrito na etapa anterior. A nbutilamina não foi usada e no seu lugar foi acrescentado etanol $\left(\mathrm{C}_{2} \mathrm{H}_{6} \mathrm{O}\right)$ na proporção molar etanol/SiO $\mathrm{Si}_{2}=1$ para as amostras ETI, ETII, ETIII, ETIV e ETV, e proporção molar etanol $/ \mathrm{SiO}_{2}=0,5$ nas amostras ETVI e ETVII. Acrescentou-se cristais de ZSM-5 à 0,02 \% da massa de sílica.

Os íons sulfato e fluoreto alteram a química do gel e tamanho dos cristais na ZSM-5 de acordo com trabalho de Carvalho et al.(1992), por isso foi estudada também a variação do íon sulfato nesta etapa.

As amostras, todas com tempo de cristalização de 50 horas, foram preparadas de acordo com a Tabela 5. 
Tabela 5 - Relação das amostras sintetizadas com etanol.

Amostra

$$
\begin{aligned}
& \text { ET I } \\
& \text { ET II } \\
& \text { ET III } \\
& \text { ET IV } \\
& \text { ET V } \\
& \text { ET VI } \\
& \text { ET VII }
\end{aligned}
$$

Etanol/SiO ${ }_{2}$

0,25

0,25

0,25

1

1

1

0,25

Tempo
de
envelh
ecime
nto $(h)$
10
48
72
10
48
48
72

\subsection{Síntese da wolastonita}

O processo proposto para a obtenção da wolastonita é uma combinação da etapa hidrotérmica a baixa temperatura, seguido de tratamento térmico (recozimento) a alta temperatura, todos estão descritos no fluxograma da Figura 19. 


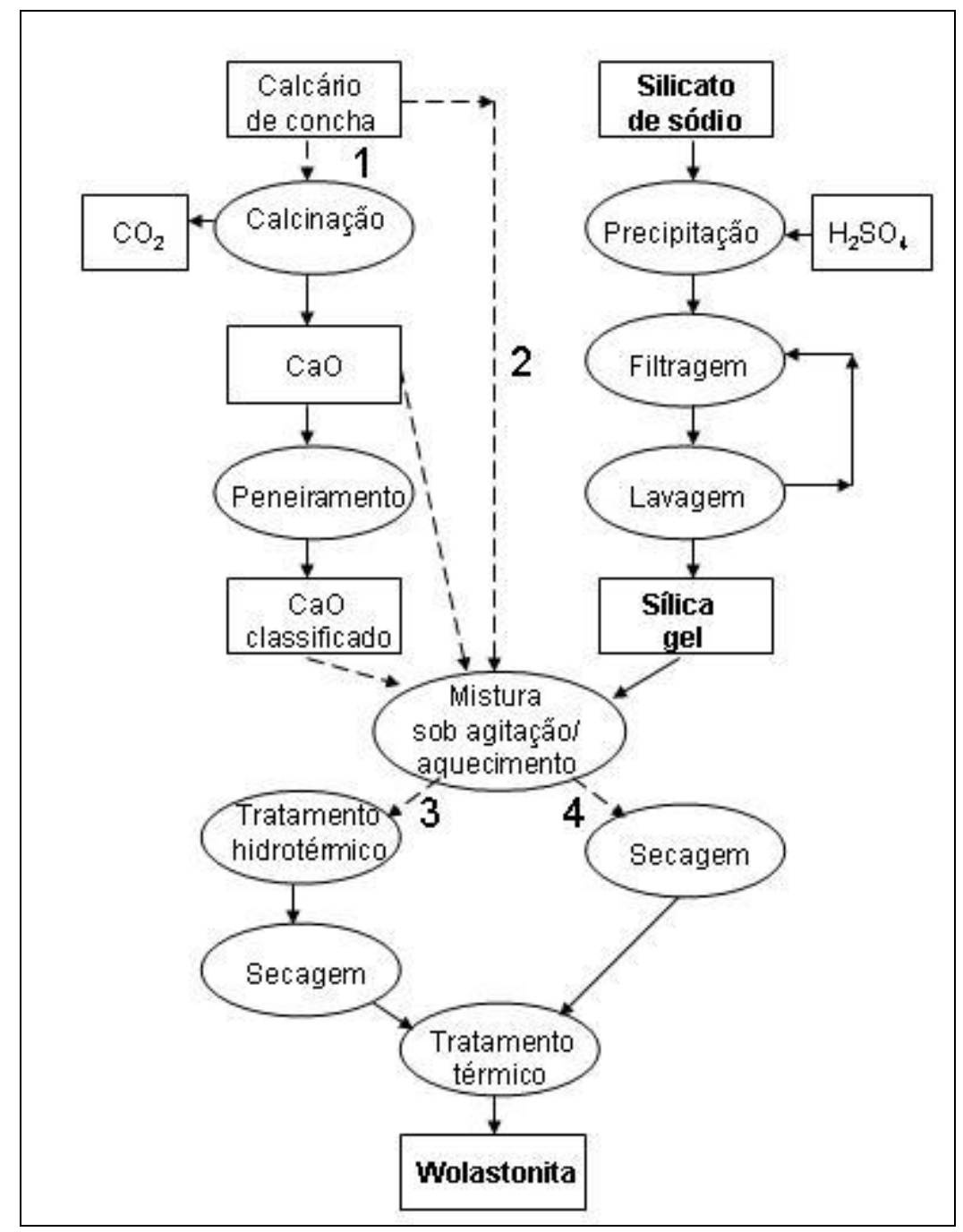

Figura 19 - Fluxograma de síntese da wolastonita.

A análise química do calcário de concha foi realizada. Assim como, experimentos com o objetivo de sintetizar uma fase única de wolastonita-2M com alto grau de cristalinidade, tendo como matéria-prima a CCA e o calcário de concha. Nos experimentos em laboratório as etapas 1, 2, 3 e 4 do fluxograma da Figura 19 foram combinadas:

Etapa 1 - Calcinação do calcário de concha em forno elétrico rotativo, com fluxo de ar de 4,0 L/h, por 1 hora. Com posterior mistura do $\mathrm{CaO}$ obtido com a sílica gel da CCA em solução aquosa sob agitação a $80^{\circ} \mathrm{C}$. Foi feito o balanço de massa do calcário de concha, na entrada e saída do forno, para quantificar a eficiência da calcinação.

Etapa 2 - Mistura direta, sob agitação do calcário de concha com a sílica gel em solução aquosa, à $80^{\circ} \mathrm{C}$. 
Etapa 3 - Tratamento hidrotérmico em autoclave de 2L, com controle de temperatura, pressão e tempo e secagem a $110^{\circ} \mathrm{C}$ por 3 horas até formar uma massa úmida.

Etapa 4 - Secagem da mistura $\mathrm{Ca}(\mathrm{OH})_{2} / \mathrm{SiO}_{2}$ por 3 horas e passagem direta para o recozimento, sem tratamento hidrotérmico.

Onze hidrossilicatos de cálcio diferentes ocorrem no sistema $\mathrm{Ca}(\mathrm{OH})_{2}-\mathrm{SiO}_{2}-\mathrm{H}_{2} \mathrm{O}$.

No recozimento este silicato de cálcio hidratado foi transformado em wolastonita-2M por recozimento em um forno elétrico.

A reação no processo total é:

$$
\mathrm{SiO}_{2}+\mathrm{CaCO}_{3} \rightarrow \mathrm{CaSiO}_{3}+\mathrm{CO}_{2} \uparrow
$$

Este processo visa um material bem cristalino, com área superfícial específica alcançando $100 \mathrm{~m}^{2} / \mathrm{g}$ e tamanho de partícula da ordem de 0,01-2 $\mu \mathrm{m}$. Uma baixa temperatura de recozimento favorece uma alta área superficial especifica.

A sílica foi extraída da CCA pelo processo igual ao das zeólitas com a posterior precipitação da mesma com ácido sulfúrico (98\%). A sílica gel é então lavada até $\mathrm{pH}=8 . \mathrm{O} \mathrm{pH}$ foi diminuído a um valor menor que 7 , nas amostras W7 em diante (Tabela 7), para garantir uma melhor lavagem, livre de $\mathrm{NaOH}$, sendo o sulfato de sódio mais fácil de lavar. A massa de sílica do gel é calculada pela perda de massa da CCA, sendo esta necessária para uma mistura estequiométrica $\mathrm{CaO} / \mathrm{SiO}_{2}=1$.

Para entender as diferentes rotas experimentadas na obtenção da wolastonita-2M, as amostras foram identificadas nas Tabela 6, 7 e 8.

Nas amostras das Tabelas 7 e 8 , na obtenção da sílica gel, o pH é diminuído pela adição de ácido sulfúrico e agitação até o valor de 6,5. Após este procedimento, a sílica gel é lavada.

Nas amostras da Tabela 8 o calcário de concha é decomposto por 1 hora, $900^{\circ} \mathrm{C}$ com leve vazão de ar. Depois foi peneirado a passante na malha \#42. Nas amostras W15, W16 e W17 foi realizado um outro peneiramento, descrito na Tabela 8.

A mistura $\mathrm{CaO} / \mathrm{SiO}_{2}$ é realizada na proporção estequiométrica por 1 hora à $80^{\circ} \mathrm{C}$ com agitação. Sendo em seguida aquecida à $150^{\circ} \mathrm{C}$ por 1 hora até formar uma massa úmida. As etapas posteriores são descritas na Tabela 8. 
O recozimento foi realizado a $900^{\circ} \mathrm{C}$ por 1 hora para todas as amostras.

Tabela 6 - Etapas no processo de síntese das amostras W1 até W6.

\begin{tabular}{|c|c|c|c|}
\hline Amostra & Etapa 1 & $\begin{array}{c}\text { Etapa } \\
2\end{array}$ & $\begin{array}{c}\text { Etapa } \\
3\end{array}$ \\
\hline W1 & $x$ & $\begin{array}{c}\text { Mistura } \\
\text { calcári } \\
0 \\
\mathrm{CaO} / \mathrm{Si} \\
\mathrm{O}_{2}=1\end{array}$ & $x$ \\
\hline W2 & $x$ & $\begin{array}{c}\text { Mistura } \\
\text { calcári } \\
\text { O } \\
\mathrm{CaO} / \mathrm{Si} \\
\mathrm{O}_{2}=1\end{array}$ & $\begin{array}{l}210^{\circ} \mathrm{C}, \\
29 \mathrm{Kgf} / \\
\mathrm{cm}^{2}, 2 \mathrm{~h}\end{array}$ \\
\hline W3 & $x$ & $\begin{array}{c}\text { Mistura } \\
\text { calcári } \\
\text { O } \\
\mathrm{CaO} \mathrm{Si} \\
\mathrm{O}_{2}=1\end{array}$ & $x$ \\
\hline W4 & $\begin{array}{c}900^{\circ} \mathrm{C}, 1 \mathrm{~h} \\
\mathrm{CaO} / \mathrm{SiO}_{2}=1,1\end{array}$ & $x$ & $x$ \\
\hline W5 & $\begin{array}{c}900^{\circ} \mathrm{C}, 1 \mathrm{~h} \\
\mathrm{CaO} / \mathrm{SiO}_{2}=0,9\end{array}$ & $x$ & $\begin{array}{l}210^{\circ} \mathrm{C}, \\
29 \mathrm{Kgf} / \\
\mathrm{cm}^{2}, 2 \mathrm{~h}\end{array}$ \\
\hline W6 & $\begin{array}{c}900^{\circ} \mathrm{C}, 1 \mathrm{~h} \\
\mathrm{CaO} / \mathrm{SiO}_{2}=0,9\end{array}$ & $x$ & $x$ \\
\hline
\end{tabular}

Tabela 7 - Etapas no processo de síntese das amostras W7 até W9.

\begin{tabular}{|c|c|c|c|}
\hline Amostra & Etapa 1 & $\begin{array}{c}\text { Etapa } \\
2\end{array}$ & $\begin{array}{c}\text { Etapa } \\
3\end{array}$ \\
\hline W7 & $\begin{array}{c}900^{\circ} \mathrm{C}, 1 \mathrm{~h} \\
\mathrm{CaO} / \mathrm{SiO}_{2}=1\end{array}$ & $x$ & $x$ \\
\hline W8 & $\begin{array}{c}900^{\circ} \mathrm{C}, 1 \mathrm{~h} \\
\mathrm{CaO} / \mathrm{SiO}_{2}=1 \\
\mathrm{Mistura} \mathrm{da} \\
\text { solução aq. } \\
90^{\circ} \mathrm{C}, 2 \mathrm{~h} \\
\end{array}$ & $x$ & $x$ \\
\hline W9 & $\begin{array}{c}900^{\circ} \mathrm{C}, 1 \mathrm{~h} \\
\mathrm{CaO} / \mathrm{SiO}_{2}=1 \\
\text { Mistura da } \\
\text { solução aq. } \\
90^{\circ} \mathrm{C}, 2 \mathrm{~h}\end{array}$ & $X$ & $\begin{array}{c}250^{\circ} \mathrm{C} \\
48 \mathrm{Kgf} \\
/ \mathrm{cm}^{2} \\
6 \mathrm{~h}\end{array}$ \\
\hline
\end{tabular}


Tabela 8 - Peneiramento e etapa 6 na síntese das amostras W10 até W17.

\begin{tabular}{|c|c|c|}
\hline Amostra & Peneiramento & Etapa 3 \\
\hline W10 & $\# 42$ & X \\
\hline W11 & $\# 42$ & $200^{\circ} \mathrm{C}, 2 \mathrm{~h}$, \\
& $\# 42$ & $24 \mathrm{Kgf} / \mathrm{cm}^{2}$ \\
\hline \multirow{2}{*}{ W12 } & \multirow{2}{*}{$\# 42 \mathrm{C}, 2 \mathrm{~h}}$, \\
& $43 \mathrm{Kgf} / \mathrm{cm}^{2}$ \\
\hline \multirow{2}{*}{ W13 } & \multirow{2}{*}{$\# 42$} & $200^{\circ} \mathrm{C}, 6 \mathrm{~h}$, \\
& & $25 \mathrm{Kgf} / \mathrm{cm}^{2}$ \\
\hline \multirow{2}{*}{ W14 } & \multirow{2}{*}{ \#80 > x \#100 } & $240^{\circ} \mathrm{C}, 6 \mathrm{~h}$, \\
& & $43 \mathrm{Kgf} / \mathrm{cm}^{2}$ \\
\hline \multirow{2}{*}{ W15 } & \multirow{2}{*}{ \#100 > x > \#325 } & $240^{\circ} \mathrm{C}, 6 \mathrm{~h}$, \\
& & $43 \mathrm{Kgf} / \mathrm{cm}^{2}$ \\
\hline \multirow{2}{*}{ W16 } & \multirow{2}{*}{ Passante \#325 } & $240^{\circ} \mathrm{C}, 6 \mathrm{~h}$, \\
& & $43 \mathrm{Kgf} / \mathrm{cm}^{2}$ \\
\hline \multirow{2}{*}{ W17 } & & $240^{\circ} \mathrm{C}, 6 \mathrm{~h}$, \\
& & $43 \mathrm{Kgf} / \mathrm{cm}^{2}$ \\
\hline
\end{tabular}

\subsection{Métodos de caracterização}

Todas as fases cristalográficas foram identificadas por difração de raios $X$ com um difratômetro Siemens, com radiação CuKa, no Instituto de Geociências da USP. $O$ ângulo $2 \theta$ variando de $3^{\circ}$ a $65^{\circ}$ com passo de $0,05^{\circ}$ e tempo de passo de $1 \mathrm{~s}$.

As análises químicas quantitativas dos pós foram feitas por fluorescência de raios X, em equipamento da PHILIPS, modelo PW 2400. As amostras são quarteadas, pulverizadas, homogeneizadas e secas a $110^{\circ} \mathrm{C}$. Sendo a varredura executada a partir da pastilha prensada. O método de varredura química consiste de análise semi-quantitativa por meio do software Semi-Q da PHILIPS. Os ensaios foram realizados no Departamento de Geologia da Universidade Federal do Paraná. Antes da análise química, os pós foram lavados sob agitação e filtrados. 
A análise química da solução de silicato de sódio foi realizada no laboratório de análises químicas e ambiental do Ipen. A técnica utilizada foi a ICPOES (Inductively coupled plasma - Optical emission spectrometry).

Os ensaios de área superficial específica e volume dos microporos foram realizados no laboratório de processamento químico no Ipen. Foi usado o aparelho GEMINI 2370 da Micrometrics com gás $\mathrm{N}_{2}$ na temperatura de $77 \mathrm{~K}$. $\mathrm{O}$ volume total de microporos foi obtido da isoterma de adsorção de nitrogênio a $P / P_{0}=1$ e a área superficial específica $(B E T)$ a $P / P_{0}=0,3$.

A morfologia foi estudada através do microscópio eletrônico de varredura $(\mathrm{MeV})$ do Ipen.

O ensaio de troca iônica foi realizado em Santa Catarina pela empresa Quimivale. É importante estabelecer condições de equilíbrio com um cátion específico no qual o produto sintético tem uma alta seletividade; considerando:

$$
A Z+B_{a q}=B Z+A_{a q}
$$

No equilíbrio o cátion $A$, na zeólita $Z$, é deslocado pela seletividade do cátion $B$ na fase aquosa. $O$ seguinte procedimento foi realizado em que o cátion $B$ é o íon amônio:

1 - Pesar alíquotas apropriadas de zeólita em tubos de polietileno selados.

2 - Adicionar volumes iguais, de uma solução de nitrato de amônio de concentração conhecida, nos tubos e misturar a temperatura ambiente. A relação volumétrica sólido/solução deve ser no mínimo 1/20.

3 - Em intervalos de tempo apropriados, remover cada tubo é determinar a concentração do cátion A na solução.

4 - Construir um gráfico da concentração de A na solução em função do tempo. O eixo vertical pode ser expresso em capacidade fracional do equilíbrio assumindo como $100 \%$ a capacidade teórica calculada.

A Quimivale realizou um teste industrial com $2 \mathrm{~kg}$ de zeólita $\mathrm{A}$, preparada da CCA, como aditivo de sabão em pó. 


\section{RESULTADOS}

\subsection{Extração da Sílica}

A análise química da casca queimada à baixa temperatura foi de $87 \%$ de teor de sílica e a queimada à alta temperatura em $94 \%$. A análise por difração de raios $X$ teve como resultado, sílica na forma amorfa e como cristobalita (Figura 20) somente na CCA queimada à alta temperatura. Na CCA queimada a baixa temperatura somente a fase amorfa.

$\mathrm{Na}$ lixiviação da CCA, queimada a baixa temperatura, ainda possui uma grande quantidade de matéria orgânica, sendo esta lixiviada junto do silicato, formando uma solução de cor âmbar.

$\mathrm{Na}$ CCA queimada a alta temperatura apesar de formar uma pequena fase de cristobalita (DRX), a matéria orgânica é quase totalmente eliminada, resultando em um silicato incolor e tendo um alto grau de extração (ver gráfico da Figura 21). 


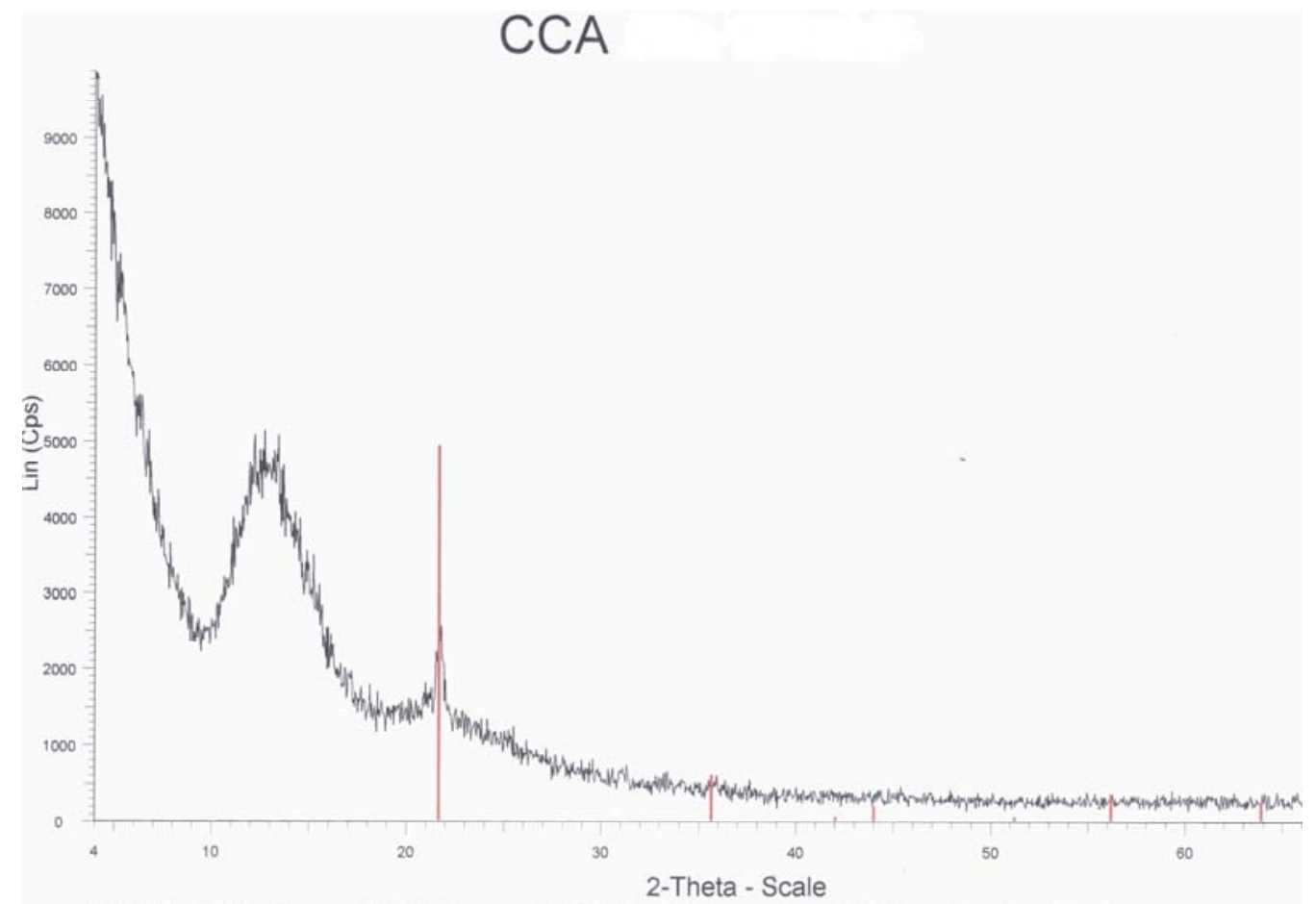

Figura 20 - Difratograma de raio $X$ da CCA queimada a $1100^{\circ} \mathrm{C}$. O padrão em vermelho é referente a fase cristobalita.

CCA Uruguaiana-RS 94\% sílica

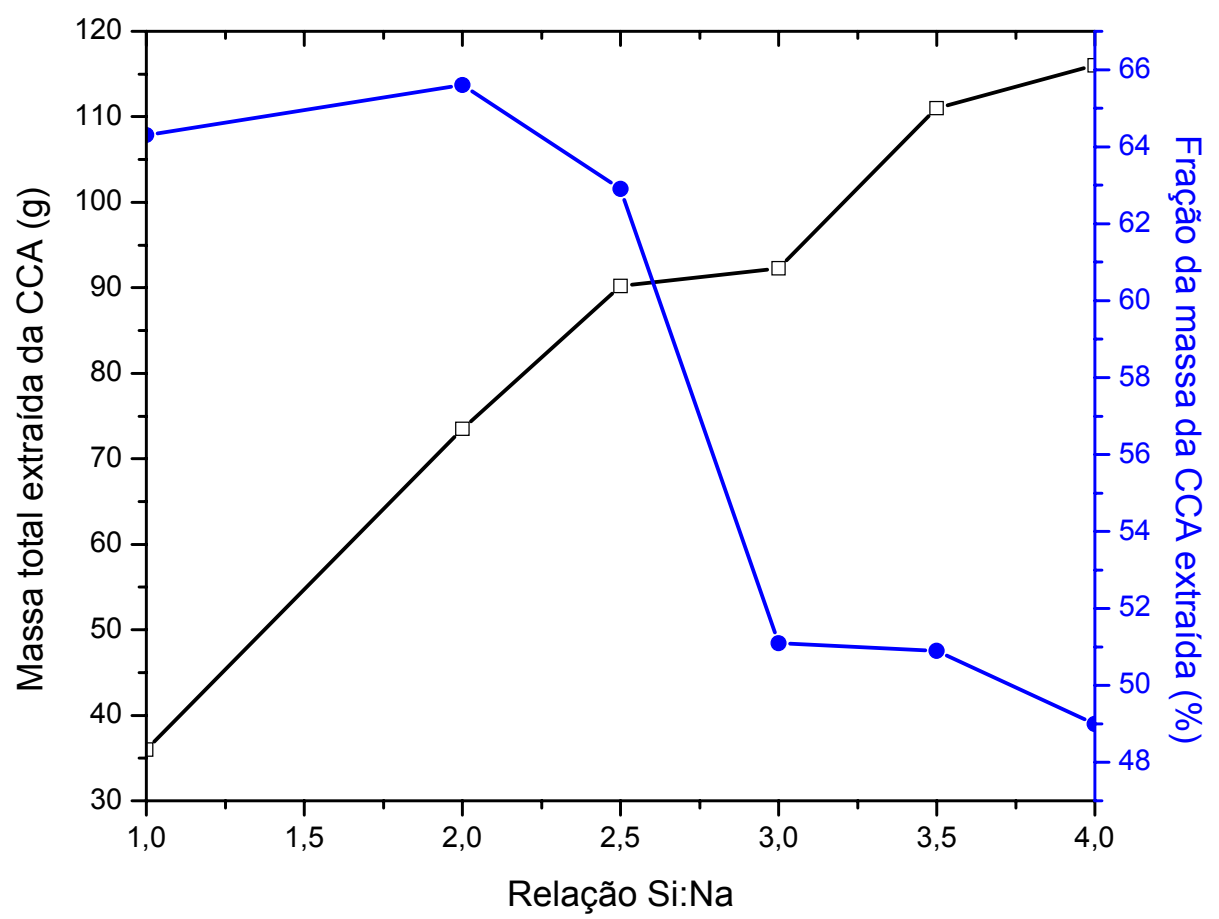

Figura 21-Massa de sílica extraída, em valor absoluto e porcentagem da CCA, queimada a alta temperatura, em função das diferentes relações de silício e sódio. 
No gráfico da Figura 21, pode-se reparar que existe uma condição ótima da extração da sílica na relação $\mathrm{Si} / \mathrm{Na}$ de 4,0. Acima disto, a massa de sílica extraída não aumenta e em termos percentuais diminui consideravelmente. Nas relações 4,5 e 5,0 a quantidade de massa total extraída foi 122 e $124 \mathrm{~g}$ respectivamente, com frações de massa extraída de 40 e $36 \%$.

$\mathrm{Na}$ Tabela 4 estão os resultados do silicato de sódio para as diferentes relações Si/Na do gráfico da Figura 21.

Tabela 9: Resultados das soluções de silicato de sódio.

\section{Relação}

em

massa

$\mathrm{Na}_{2} \mathrm{O}(\%)$

$\mathrm{SiO}_{2}(\%)$

$\mathrm{H}_{2} \mathrm{O}$ (\%)

\section{Sólidos}

Totais (\%)

$$
\begin{gathered}
\text { Relação } \\
\text { molar } \\
\mathrm{SiO}_{2} I \\
\mathrm{Na}_{2} \mathrm{O}
\end{gathered}
$$


A comparação de densidades entre a solução com o silicato comercial analítico e o silicato obtido da CCA foi realizado com sucesso. Pode-se ver na Figura 22 que os gráficos estão em concordância, validando o cálculo de massa através da diferença de massa da CCA e fornecendo uma relação densidade/concentração.

Há apenas uma pequena diferença para sólidos totais, em função das diferentes relações Si/Na no silicato de sódio, isto é, o sódio calculado pode estar em solução como cátion ou $\mathrm{Na}_{2} \mathrm{O}$ no silicato.

Também em baixas quantidades de CCA lixiviada ocorreu um desvio nos gráficos. Talvez devido à baixa precisão nos cálculos com pequenas massas.

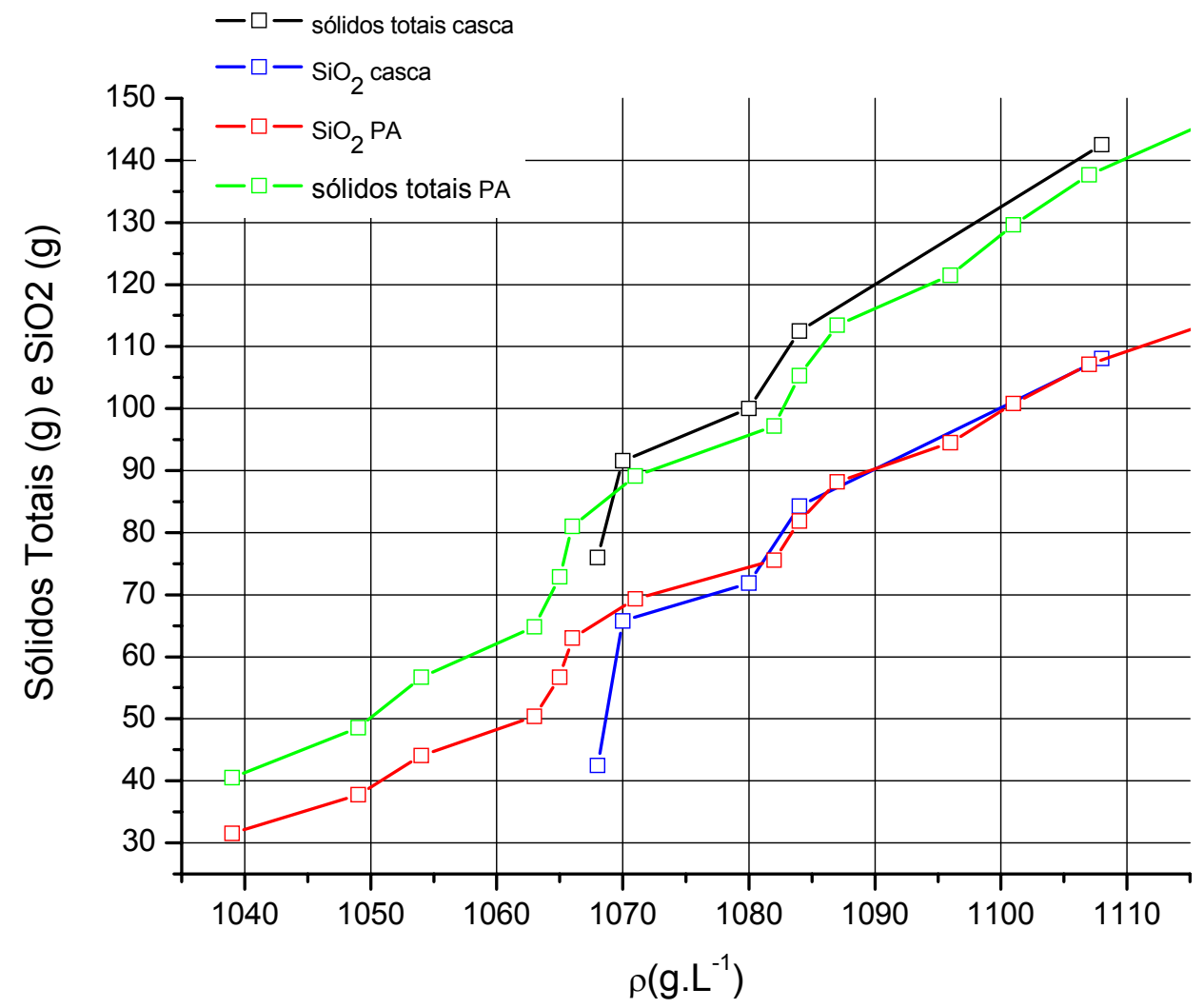

Figura 22- Gráfico de densidade entre o silicato de sódio (P.A.) e o silicato obtido da CCA.

\subsection{Síntese da zeólita A}

\subsubsection{Difração de raios $X$.}


O resultado da difração de raios $X$ na amostra $A 1$ mostrou a formação da fase zeólita $X$ (Figura 23) bem cristalina e definida, sem uma segunda fase. A zeólita $X$ tem fórmula $\mathrm{Na}_{86}\left[\left(\mathrm{AlO}_{2}\right)_{86}\left(\mathrm{SiO}_{2}\right)_{106}\right] .264 \mathrm{H}_{2} \mathrm{O}$, relação Si/Al entre 1 e 1,5, a SBU é a D6R. Sua estrutura é formada de 12 anéis de 7,4 $\AA$ e 6 anéis de 2,2 $\AA$.

$\mathrm{Na}$ amostra A2 a zeólita A apareceu como fase concorrente da zeólita X (Figura 24).

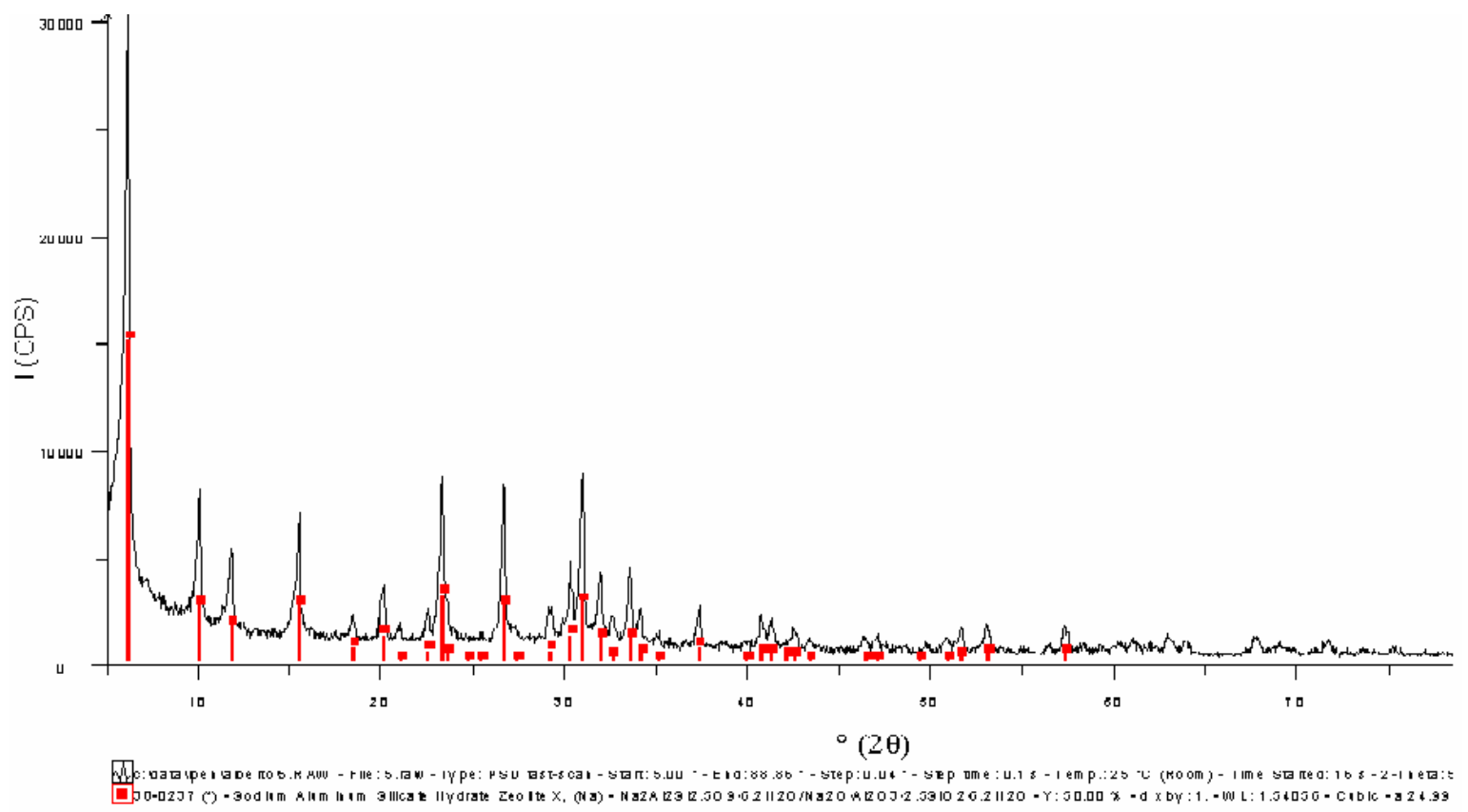

Figura 23 - Difratograma de raios $X$ da amostra $A 1$, que mostra a nucleação da zeólita $X$. O padrão em vermelho é referente a fase zeólita $X$. 


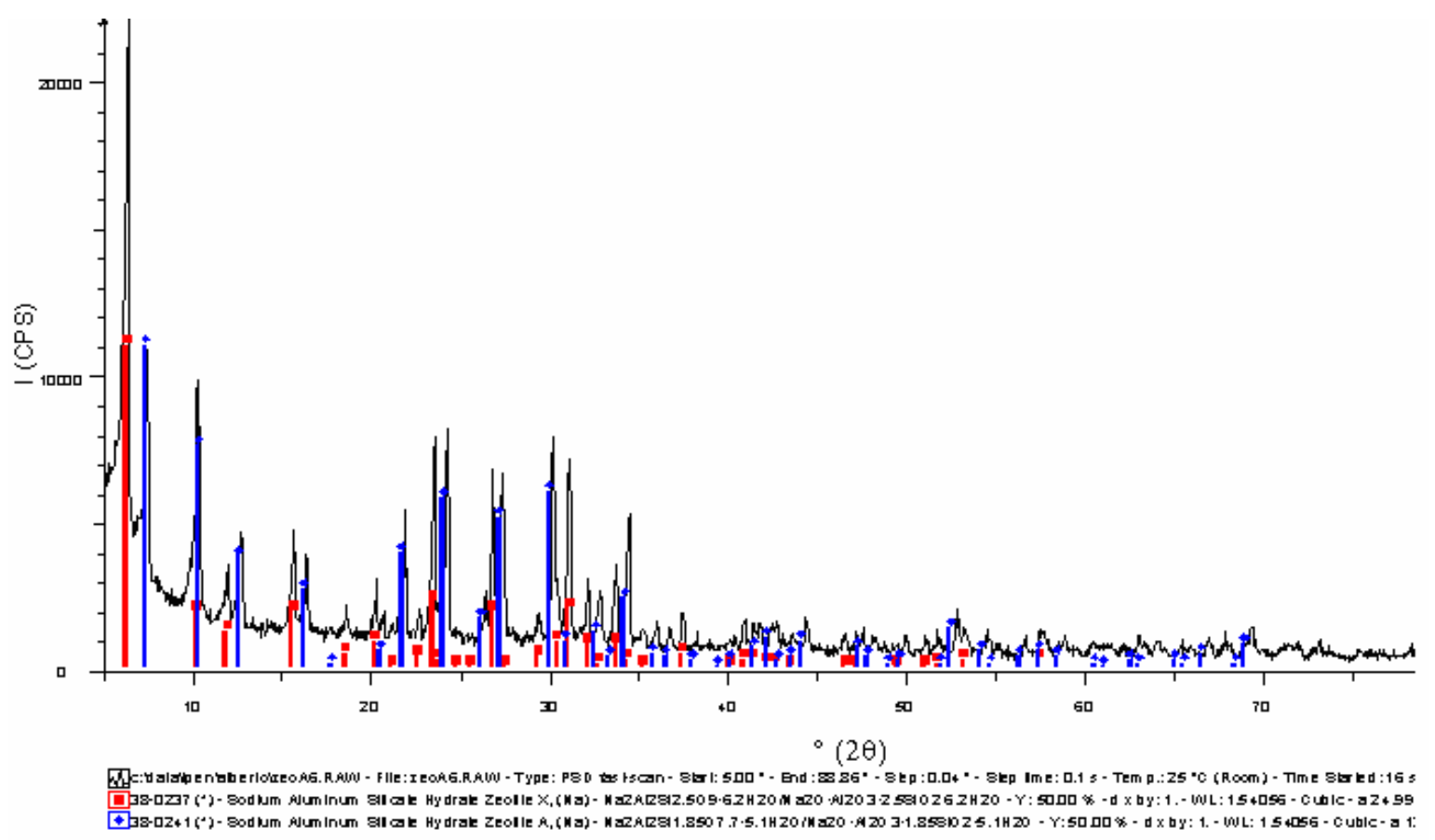

Figura 24: Difratograma de raios $X$ da amostra $A 2$, que mostra a nucleação das fases A e X. O padrão em vermelho é referente a fase zeólita X, e o azul, a zeólita A.

Na amostra $A 3$ obtivemos a formação somente da zeólita $A$ com um alto grau de cristalinidade (Figura 25). A amostra $A 4$ cristalizou a fase $P$ somente (Figura 26). A amostra A5 cristalizou a fase A com baixa cristalinidade (Figura 27), e a amostra A6 teve um baixo índice de cristalização sendo difícil identificar alguma fase formada (Figura 28). 


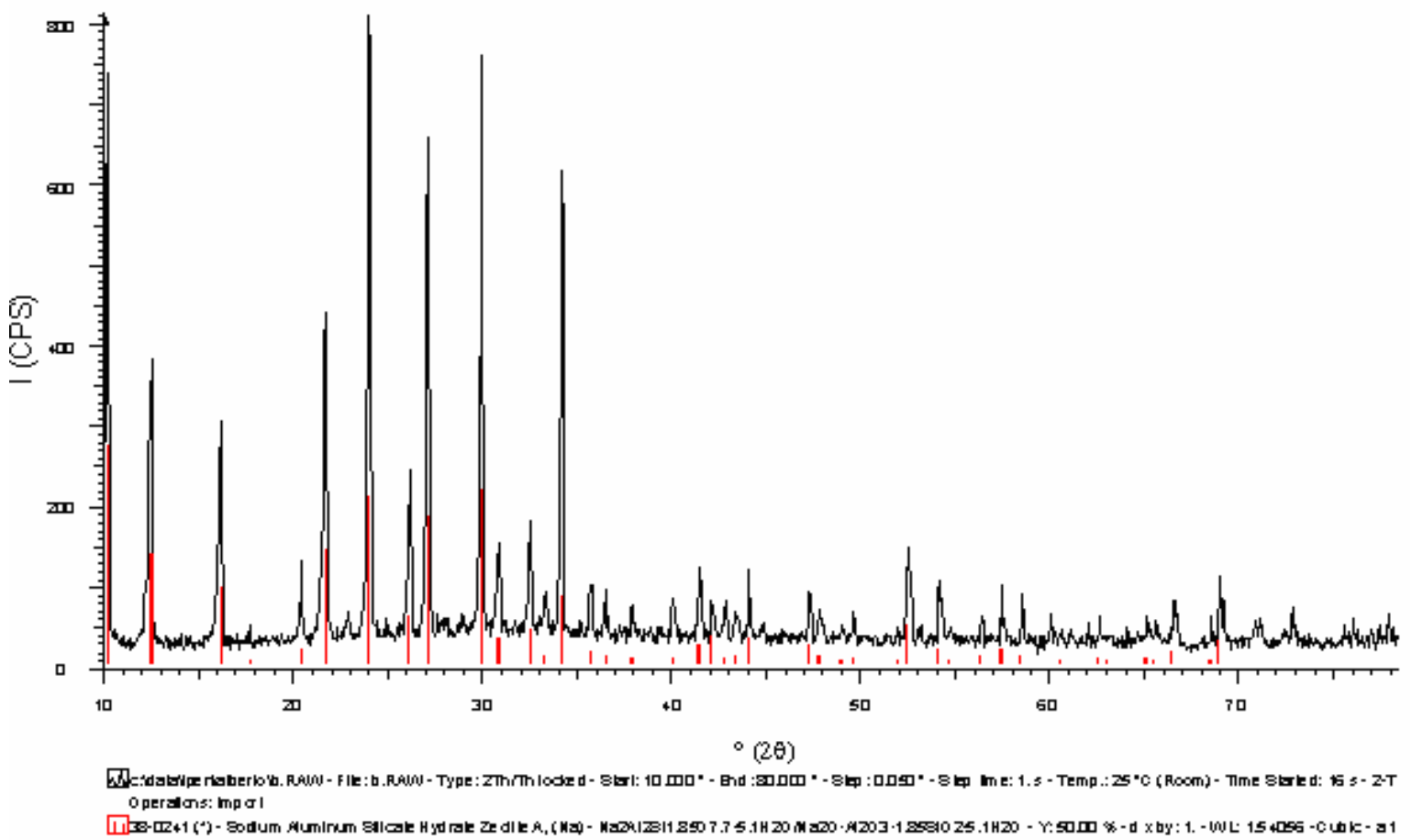

Figura 25- Difratograma de raios $X$ da amostra $A 3$, que mostra a zeólita $A$. $O$ padrão em vermelho é referente a fase zeólita $A$.

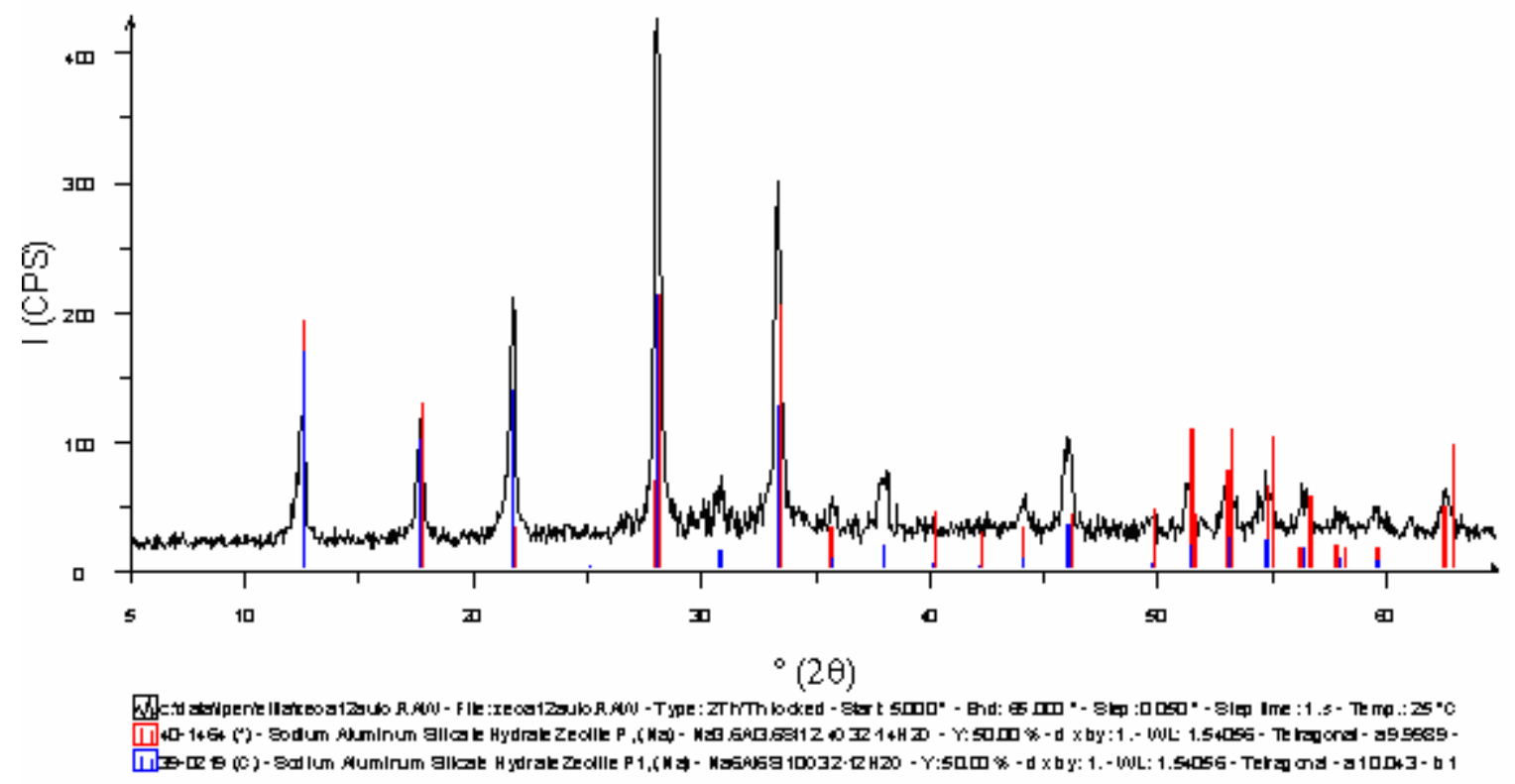

Figura 26- Difratograma de raios $X$ da amostra A4 com cristalização da zeólita $P$. $\mathrm{O}$ padrão em vermelho é referente a fase zeólita $\mathrm{P}$, e o azul à $\mathrm{P} 1$. 


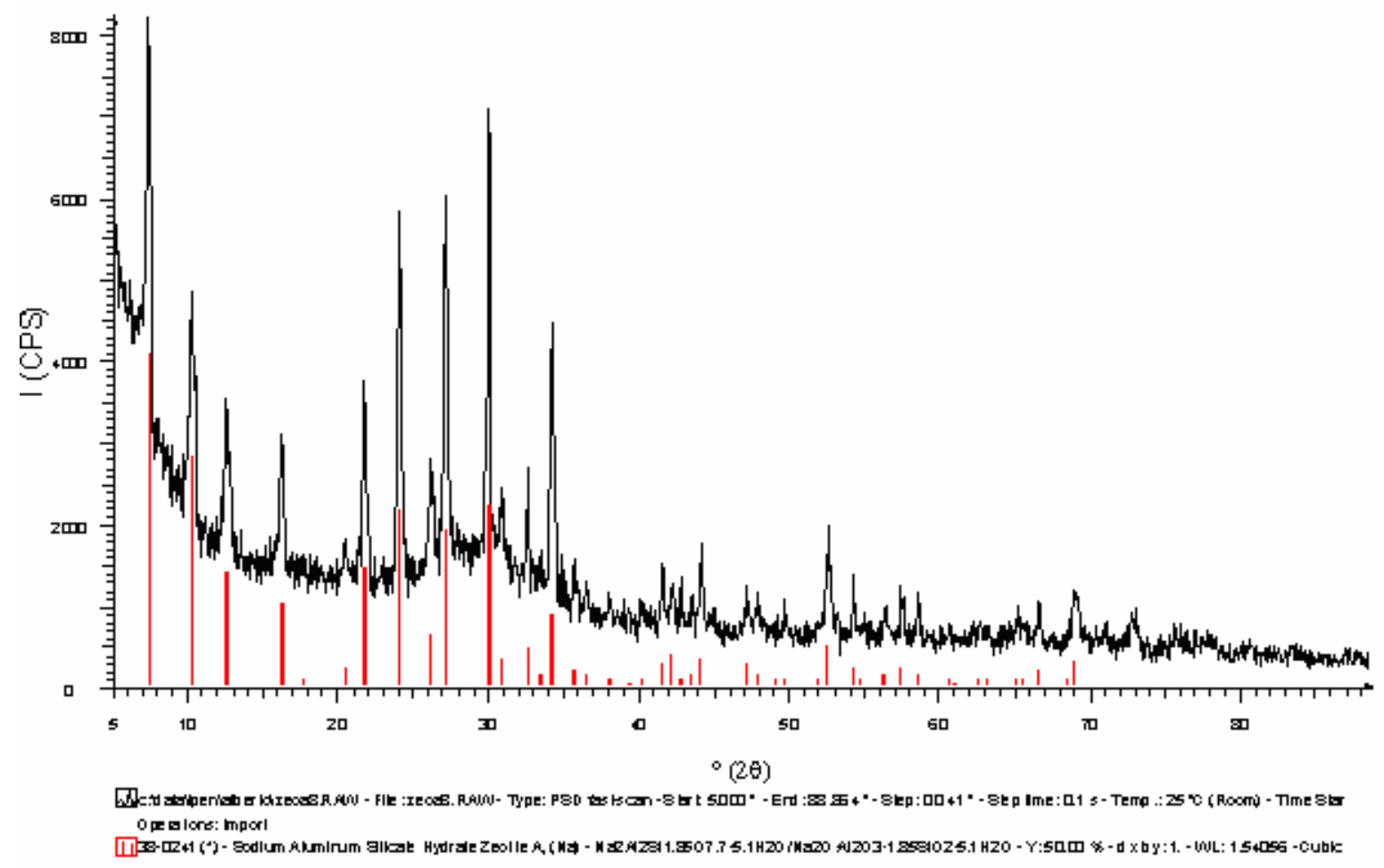

Figura 27 - Difratograma de raios $X$ da amostra A5. O padrão em vermelho é referente a fase zeólita $A$.

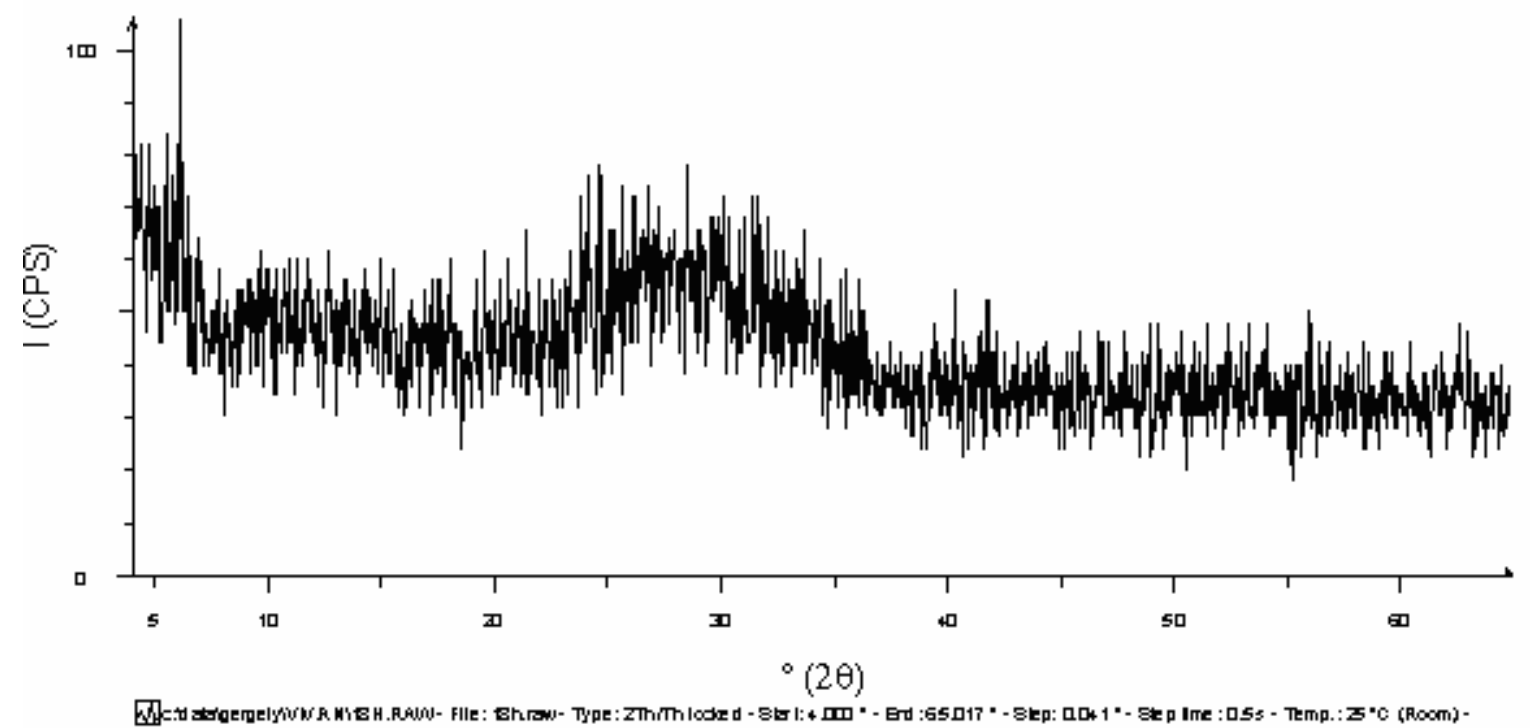

Figura 28 - Difratograma de raios $\mathrm{X}$ da amostra A6.

\subsubsection{Medidas físicas e químicas}

A medida química por fluorescência de raios $X$ da amostra $A 3$ é relacionado na Tabela 10, comparando com a composição teórica para a zeólita A 
com fórmula $\mathrm{Na}_{10,7}\left[\left(\mathrm{AlO}_{2}\right)_{10,7}\left(\mathrm{SiO}_{2}\right)_{13,3} \cdot 30 \mathrm{H}_{2} \mathrm{O}(\right.$ Breck., 1984). Os valores estão em porcentagem de peso em relação aos óxidos.

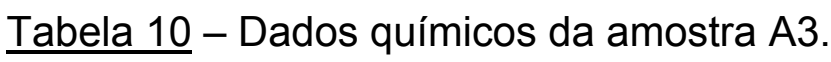

$\begin{array}{ccccc} & \mathrm{SiO}_{2} & \mathrm{Al}_{2} \mathrm{O}_{3} & \mathrm{Na}_{2} \mathrm{O} & \mathrm{CaO} \\ \begin{array}{c}\text { Amostra } \\ \text { A3 }\end{array} & 37,15 & 29,20 & 18,35 & 0,08 \\ \begin{array}{c}\text { Teórico } \\ \text { Zeólita } \\ \text { A }\end{array} & 36 & 28,5 & 18,82 & - \\ & & & & \end{array}$

A área superficial específica da amostra A3 foi de $280 \mathrm{~m}^{2} / \mathrm{g}$. O ensaio de troca iônica da amostra A3 teve como resultado um valor de $180 \mathrm{meq} / 100 \mathrm{~g}$. Um ótimo valor para o ensaio a temperatura ambiente.

A amostra de $2 \mathrm{~kg}$ feita no vaso de pressão de $20 \mathrm{~L}$ foi aprovada no teste industrial.

\subsubsection{Microscopia eletrônica de varredura (MEV)}

$\mathrm{O}$ estudo morfológico para a amostra $\mathrm{A} 3$, foi realizado utilizando um microscópio eletrônico de varredura (MEV). Mostrado nas figuras 29 e 30.

A morfologia esta de acordo com a literatura para zeólita A. Os cristais em forma de esfera são cristais de zeólita $P$.

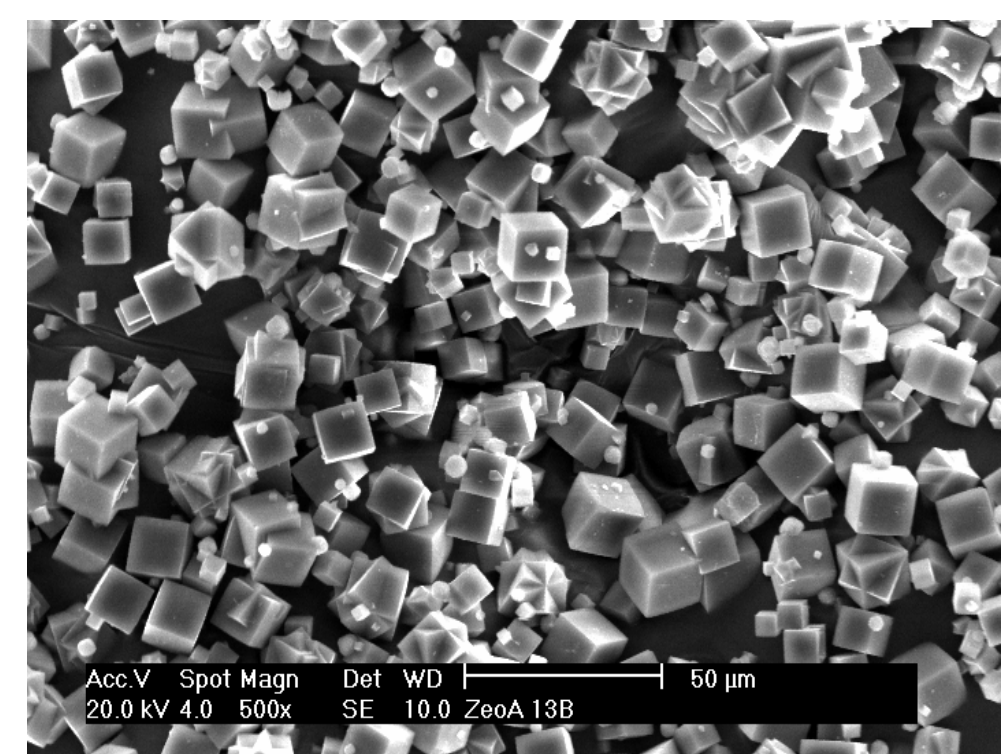

Figura 29 - Representação fotográfica do MEV para a amostra A3 com um aumento de 500x. 


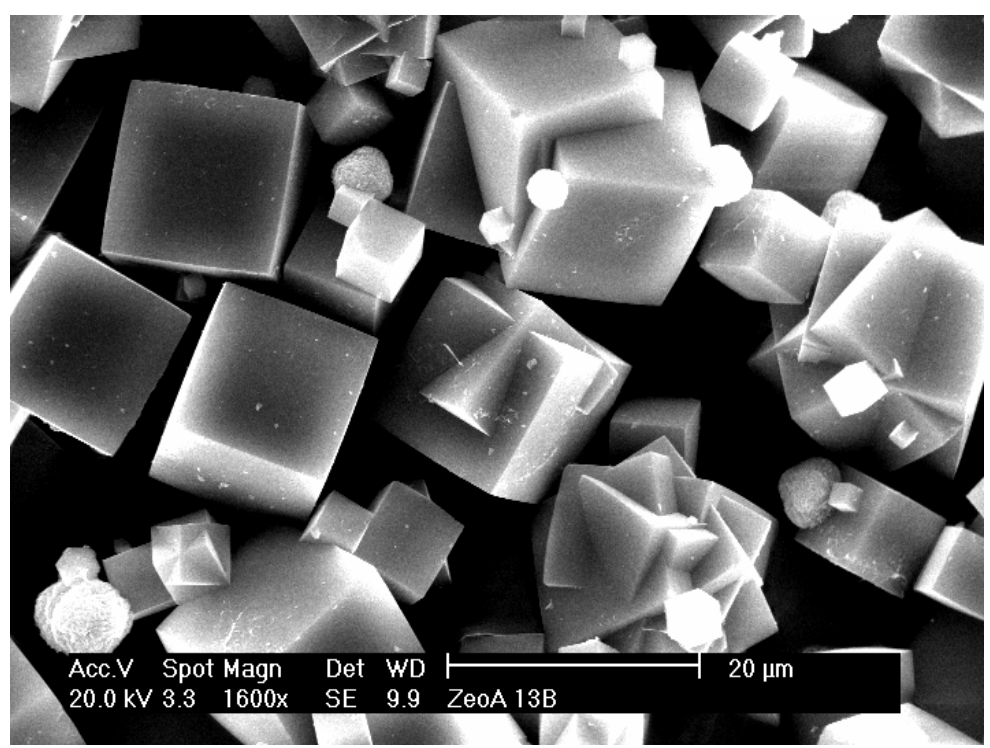

Figura 30 - Representação fotográfica do MEV para a amostra A3 com um aumento de 1600x.

\subsection{Síntese da zeólita ZSM-5}

\subsubsection{Difração de raios $X$}

Na primeira etapa, usando a sílica xerogel da CCA nas amostras Z1, Z2 e Z3, não obtivemos para nenhuma amostra uma cristalização. Na DRX o espectro é totalmente amorfo.

Para as amostras A, B, C e DZSM-5, usando o trisilicato de sódio P.A., obtivemos a fase ZSM-5 (Figura 31) bem cristalina e identificada. Os difratogramas das 4 amostras não tiveram nenhuma diferença significativa.

Nas amostras Zeo1, 2 e 3 sintetizadas à partir da CCA foi bem identificada a fase ZSM-5 (Figura 32), e apenas esta, com alto grau de cristalinidade. Não houve diferença para nenhuma das três amostras. O mesmo aconteceu para as amostras SILZ1, SILZ2 e SILZ3, com menor tempo de envelhecimento. Os difratogramas de raio $X$ mostraram a fase ZSM-5 bem definida e com alta intensidade dos picos.

Nas amostras sintetizadas sem a adição de padrão orgânico e uso do etanol tivemos a formação de ZSM-5 e mordenita (Si/AI=5, 5-1sbus, $\left.\mathrm{Na}_{8}\left[\left(\mathrm{AlO}_{2}\right)_{8}\left(\mathrm{SiO}_{2}\right)_{40}\right] .24 \mathrm{H}_{2} \mathrm{O}\right)$ nas amostras ETI (Figura 33), ETII (Figura 34) e ETIII. Na amostra ETI houve um fundo amorfo, o que não aconteceu nas amostras ETII e III.

Nas amostra ETIV e ETV (Figura 35) houve a formação de ZSM-5, mordenita e keniaita $\left(\mathrm{NaSiO}_{2} \cdot 5(\mathrm{OH}) \cdot 4,3 \mathrm{H}_{2} \mathrm{O}\right)$. 
Nas amostras ETVI e ETVII ocorreu apenas a formação da fase ZSM-5 com alto grau de cristalinidade. Não houve diferença significativa entre os dois gráficos e os gráficos das amostras Zeo 1,2 e 3.

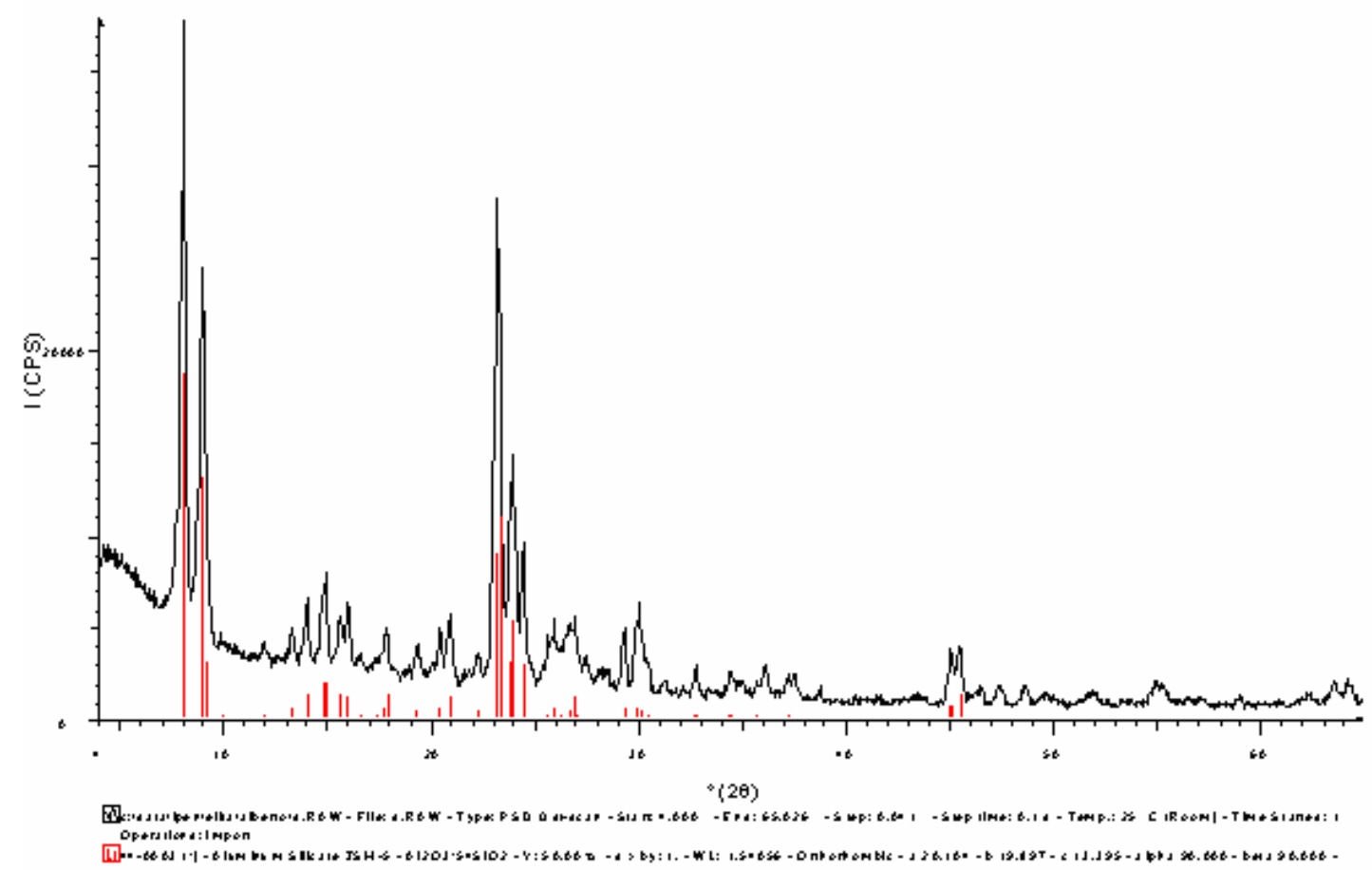

Figura 31 - Difratograma de raios $X$ da amostra AZSM-5. O padrão em vermelho é referente a fase ZSM-5.

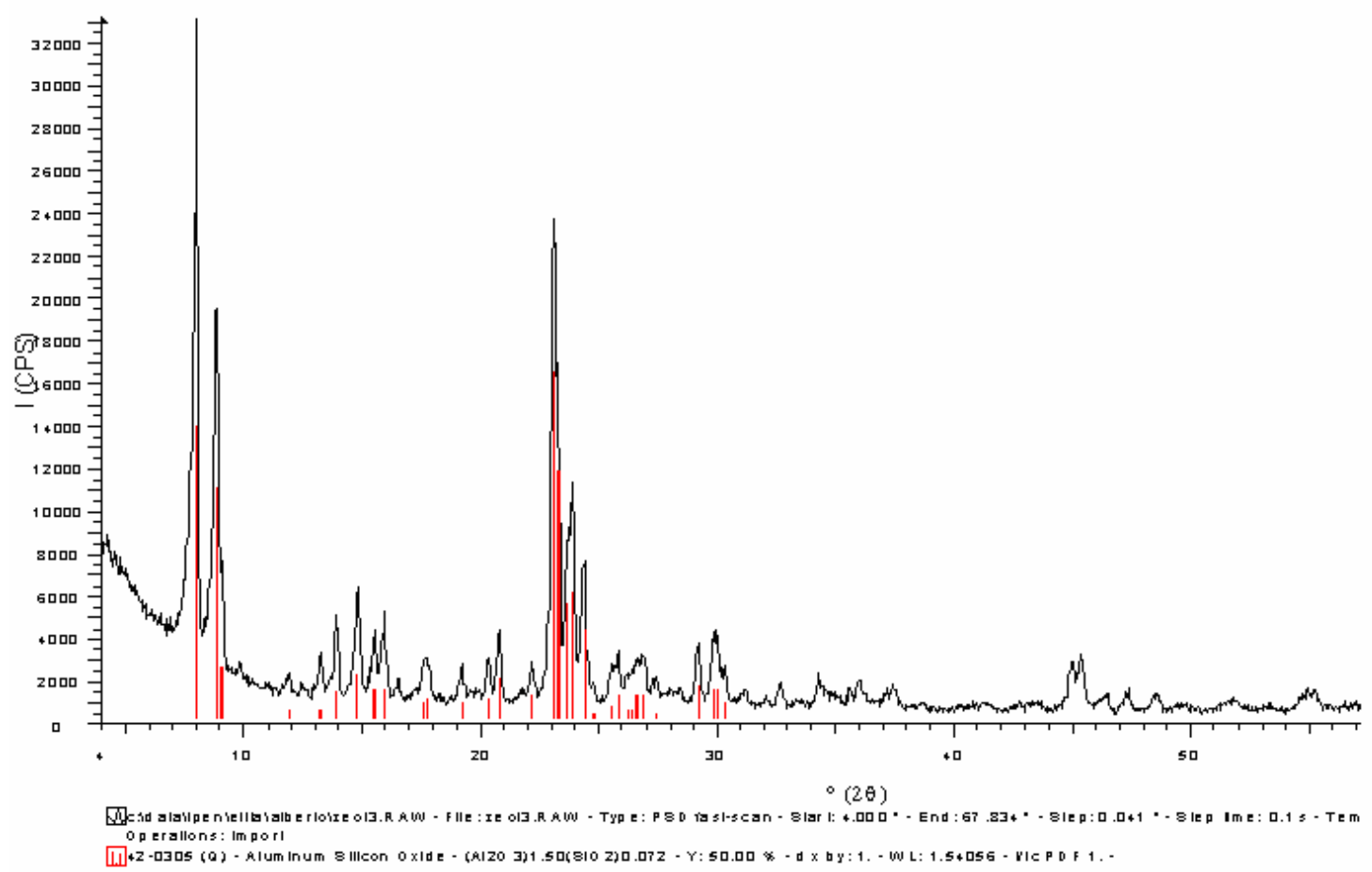

Figura 32 - Difratograma de raios $X$ da amostra Zeo2. O padrão em vermelho é referente a fase ZSM-5. 


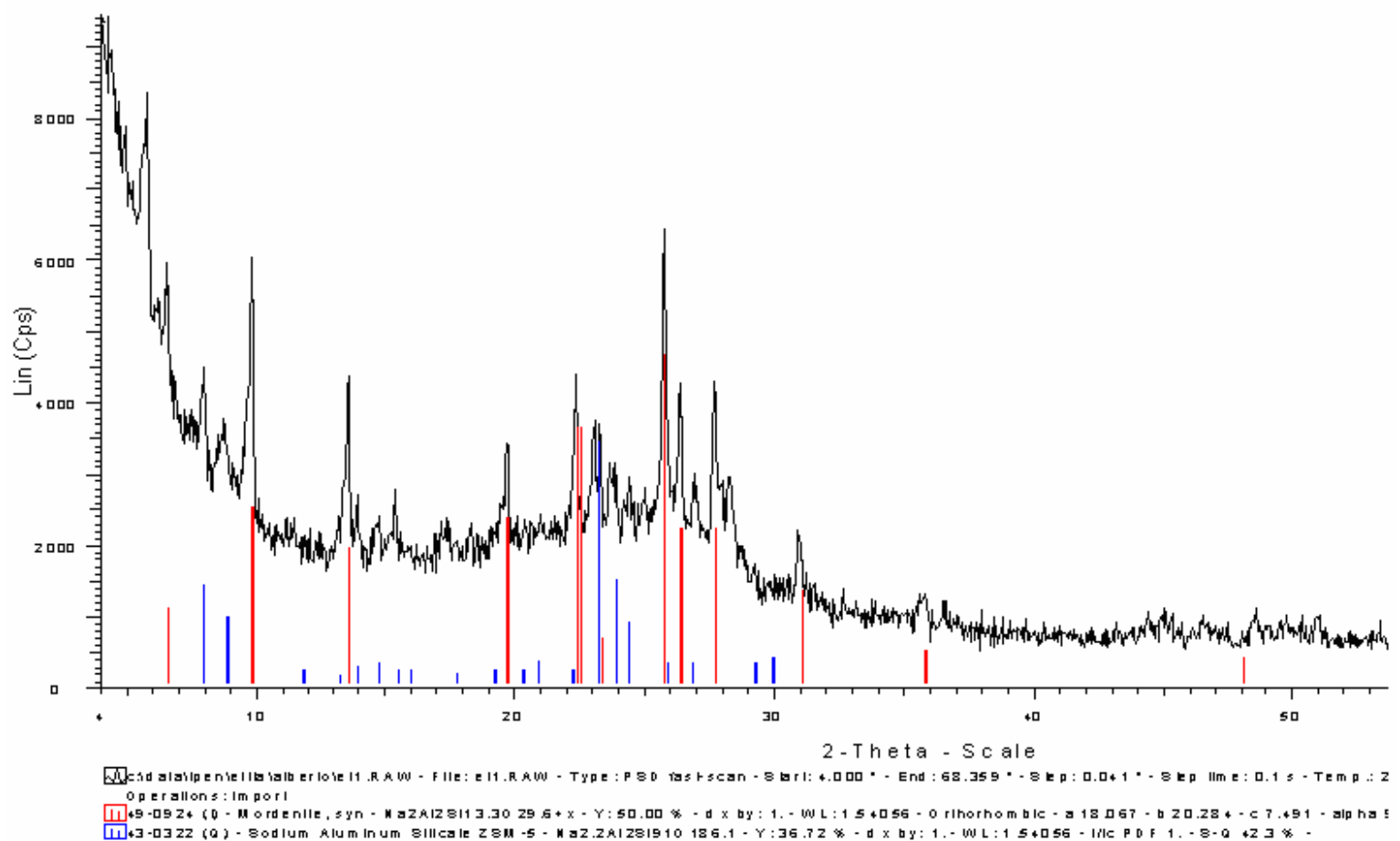

Figura 33 - Difratograma de raios $X$ da amostra ET I. O padrão em vermelho é referente a fase mordenita, e o azul, a fase ZSM-5.

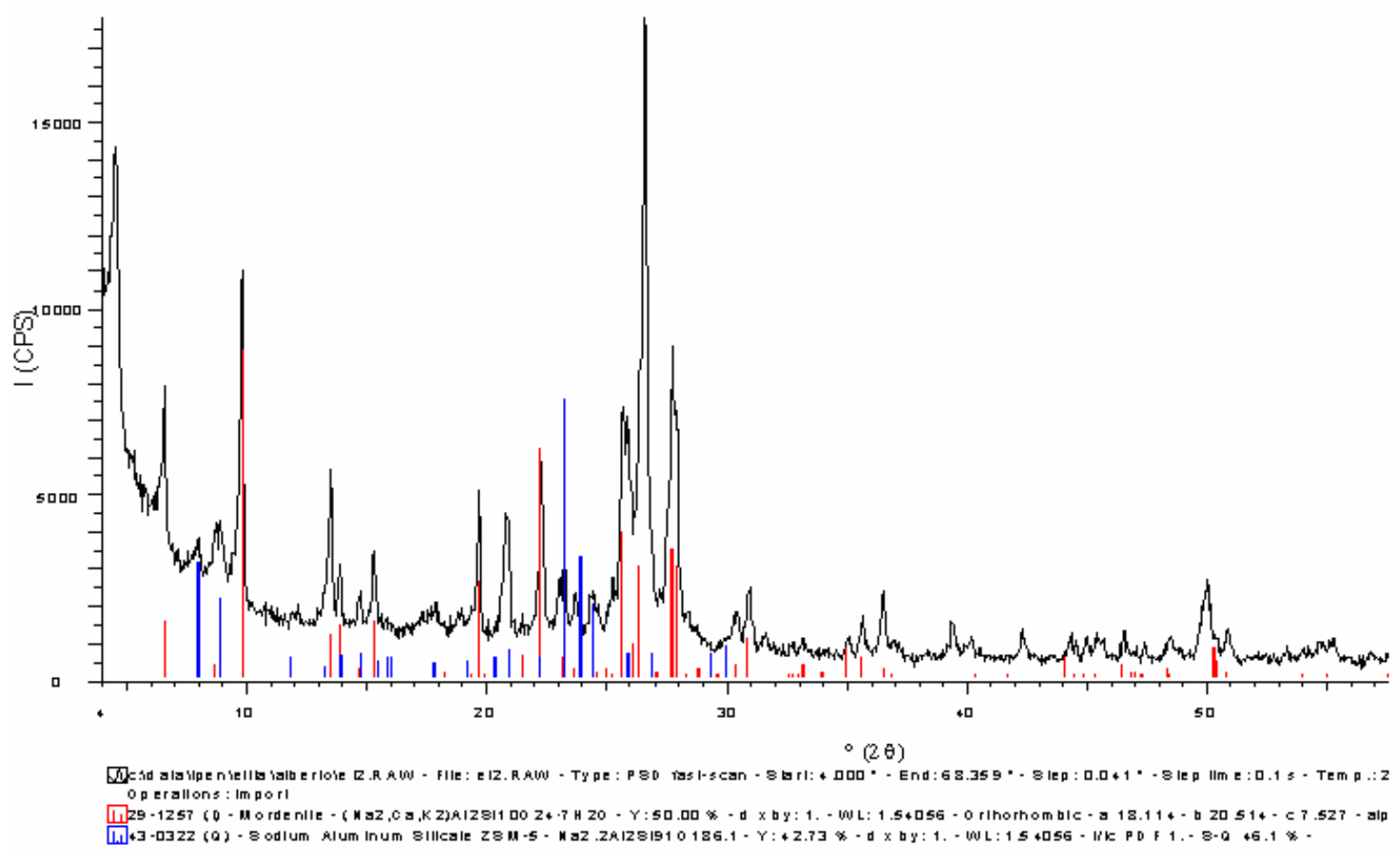

Figura 34 - Difratograma de raios $X$ da amostra ET II. O padrão em vermelho é referente a fase mordenita, e o azul, a fase ZSM-5. 


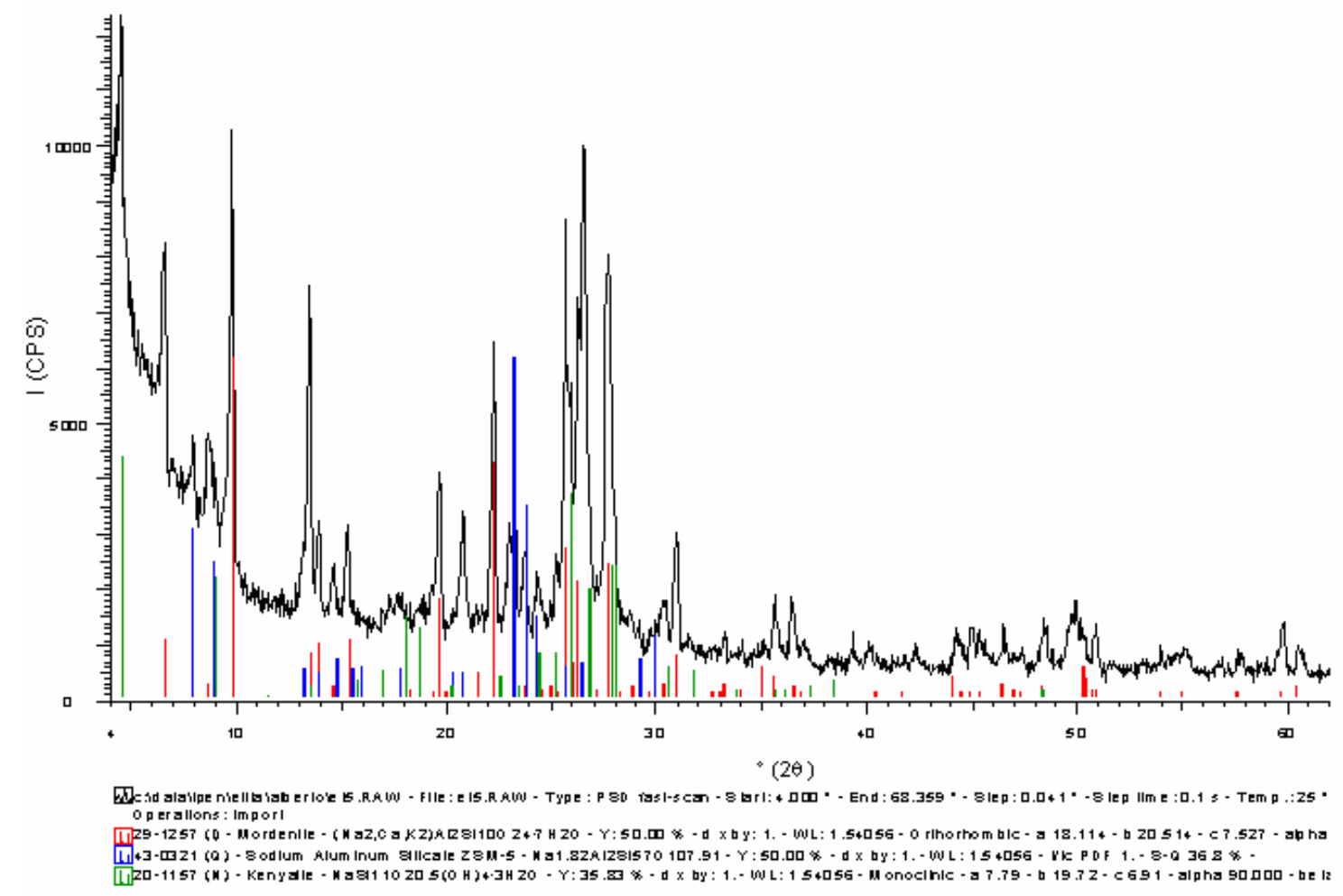

Figura 35 - Difratograma de raios $x$ da amostra ET V. O padrão em vermelho é referente a fase mordenita, o azul, a fase ZSM-5, e o verde, a fase keniaita.

\subsubsection{Isotermas de nitrogênio.}

Os valores das propriedades de superfície, tais como: área superficial específica e volume de microporos específico das amostras estão na Tabela 11. A concentração de impurezas em todas as amostras não passou de 100 ppm, sendo as principais $\mathrm{Fe}$, $\mathrm{Ti}$ e $\mathrm{Ca}$.

Tabela 11 - Análise química e física das amostras de zeólita ZSM-5.

\begin{tabular}{|c|c|c|c|}
\hline & Si/AI & $\begin{array}{c}\text { Área } \\
\text { superfici } \\
\text { al } \\
\text { específic } \\
\text { a }\left(\mathrm{m}^{2} / g\right)\end{array}$ & 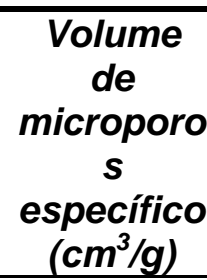 \\
\hline $\begin{array}{c}\text { AZSM- } \\
5\end{array}$ & 33,47 & 300,1 & 0,1624 \\
\hline $\begin{array}{c}\text { BZSM- } \\
5 \\
\end{array}$ & 32,74 & 305,6 & 0,1642 \\
\hline $\begin{array}{c}\text { CZSM- } \\
5 \\
\end{array}$ & 33,09 & 312,7 & 0,1680 \\
\hline $\begin{array}{c}\text { DZSM- } \\
5 \\
\end{array}$ & 32,42 & 320,7 & 0,1730 \\
\hline Zeo1 & 19,08 & 301,8 & 0,1642 \\
\hline
\end{tabular}




\begin{tabular}{|r|r|r|r|}
\hline Zeo2 & 19,82 & 302,5 & 0,1652 \\
\hline Zeo3 & 18,60 & 315,1 & 0,1733 \\
\hline SILZ1 & 18,76 & 274,6 & 0,1561 \\
\hline SILZ2 & 19,54 & 288,8 & 0,1590 \\
\hline SILZ3 & 18,55 & 262,5 & 0,1522 \\
\hline
\end{tabular}

\subsubsection{Microscopia eletrônica de varredura (MEV)}

As Figuras a seguir $(36,37$ e 38$)$ mostram as imagens das amostra DZSM-5, Zeo2 e SILZ2 obtidas por MEV. A morfologia é típica do cristal da ZSM5 para as três amostras, que é detalhado no capítulo 6. A amostra Zeo2 mostra a partícula mais alongada no plano\{100\}.

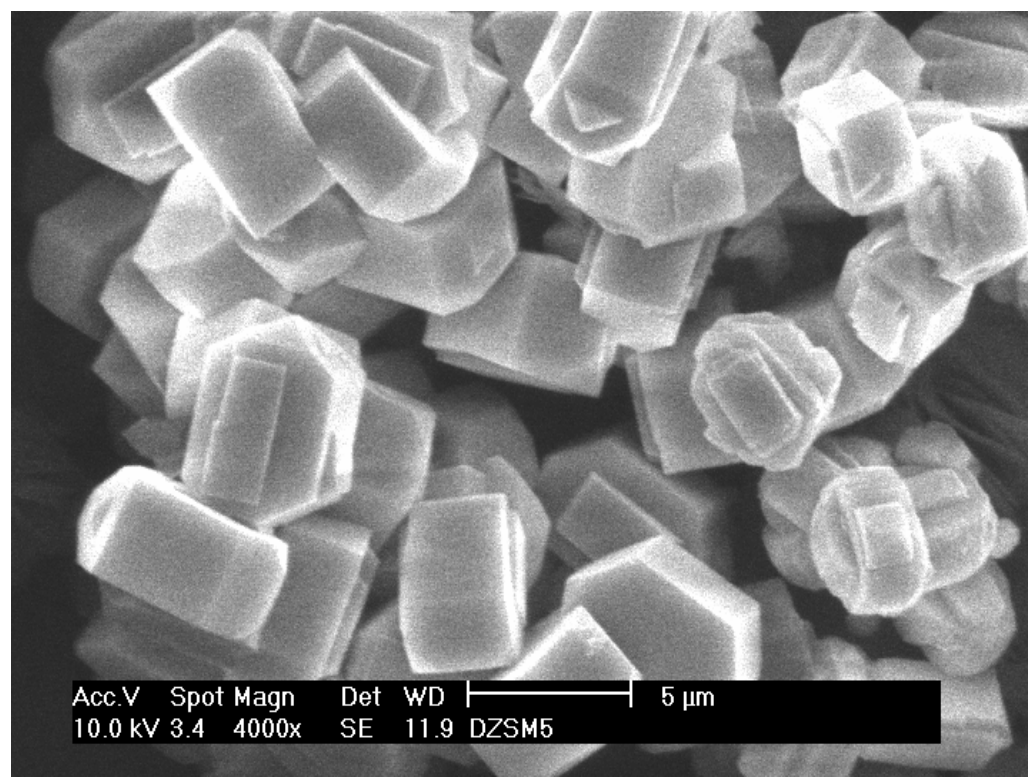

Figura 36 - Representação fotográfica do MEV da amostra DZSM-5 com aumento de 4000X. 


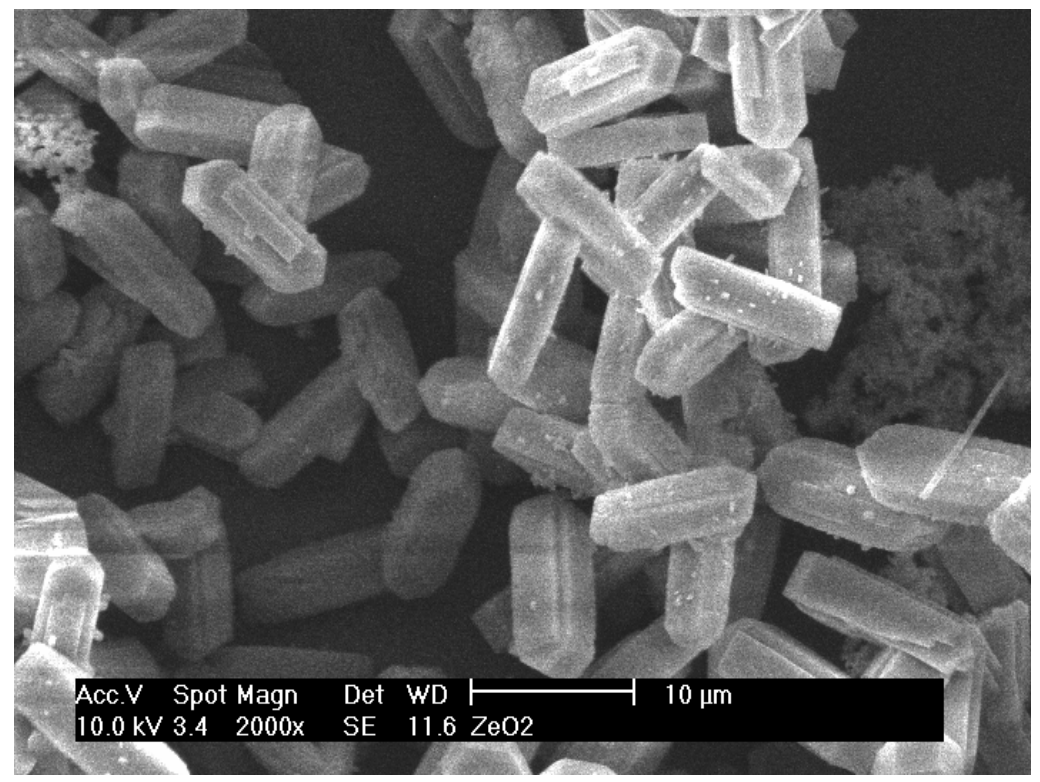

Figura 37 - Representação fotográfica do MEV da amostra Zeo2 com aumento de 2000X.

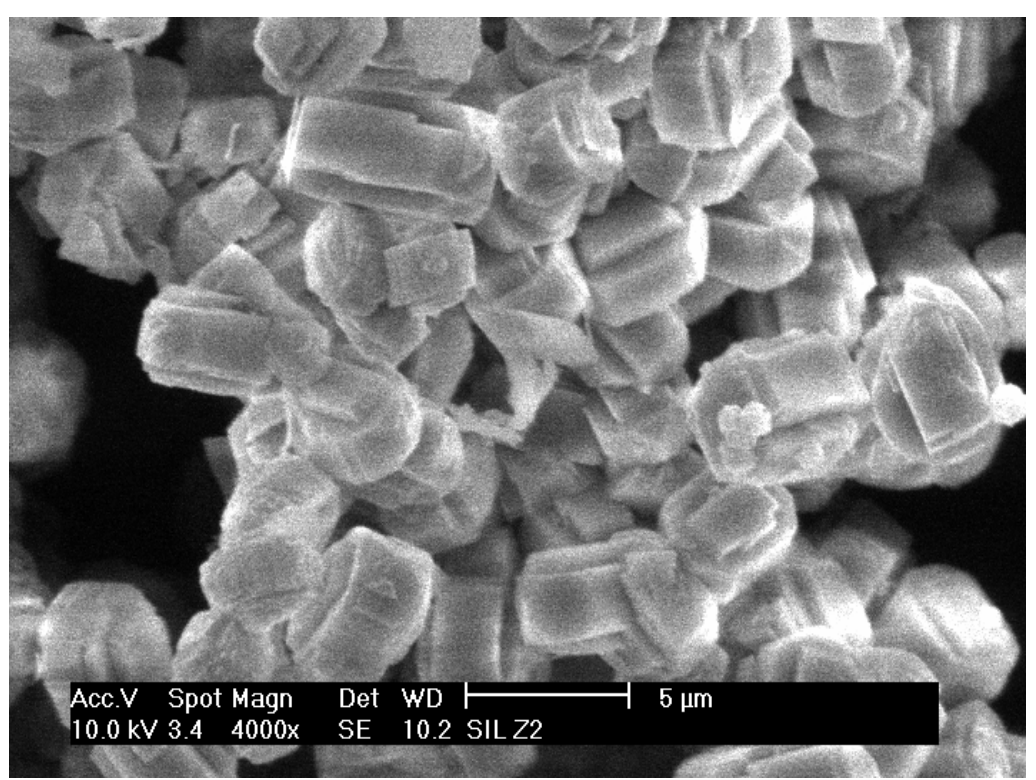

Figura 38 - Representação fotográfica do MEV da amostra SILZ2 com aumento de $4000 x$.

\subsection{Síntese da wolastonita}

$\mathrm{Na}$ análise do calcário de concha utilizado com $96 \%$ de $\mathrm{CaCO}_{3}$, foi encontrado $\mathrm{MgO}=0,17 \%, \mathrm{P}_{2} \mathrm{O}_{5}=0,023 \%$ e $\mathrm{B}_{2} \mathrm{O}_{3}=0,015 \%, \mathrm{Cu}=5 \mathrm{ppm}, \mathrm{Mn}=28$ ppm, Mo $=14$ ppm e $Z n=11$ ppm. Sendo o restante de fases que são eliminadas na perda ao fogo.

\subsubsection{Difração de raios $X$}


Nas análises de DRX para as amostra W1, W2 e W3 (Figura 39) houve a formação de wolastonita-2M, mas junto com diversas outras fases como o $\mathrm{CaCO}_{3}$ (calcita) que não foi totalmente decomposto, e tridimita $\left(\mathrm{SiO}_{2}\right)$ proveniente da sílica amorfa que não reagiu e cristalizou à alta temperatura. Nas amostra W2 e W3 também não reagiu o $\mathrm{Ca}(\mathrm{OH})_{2}$ (portlandita). 


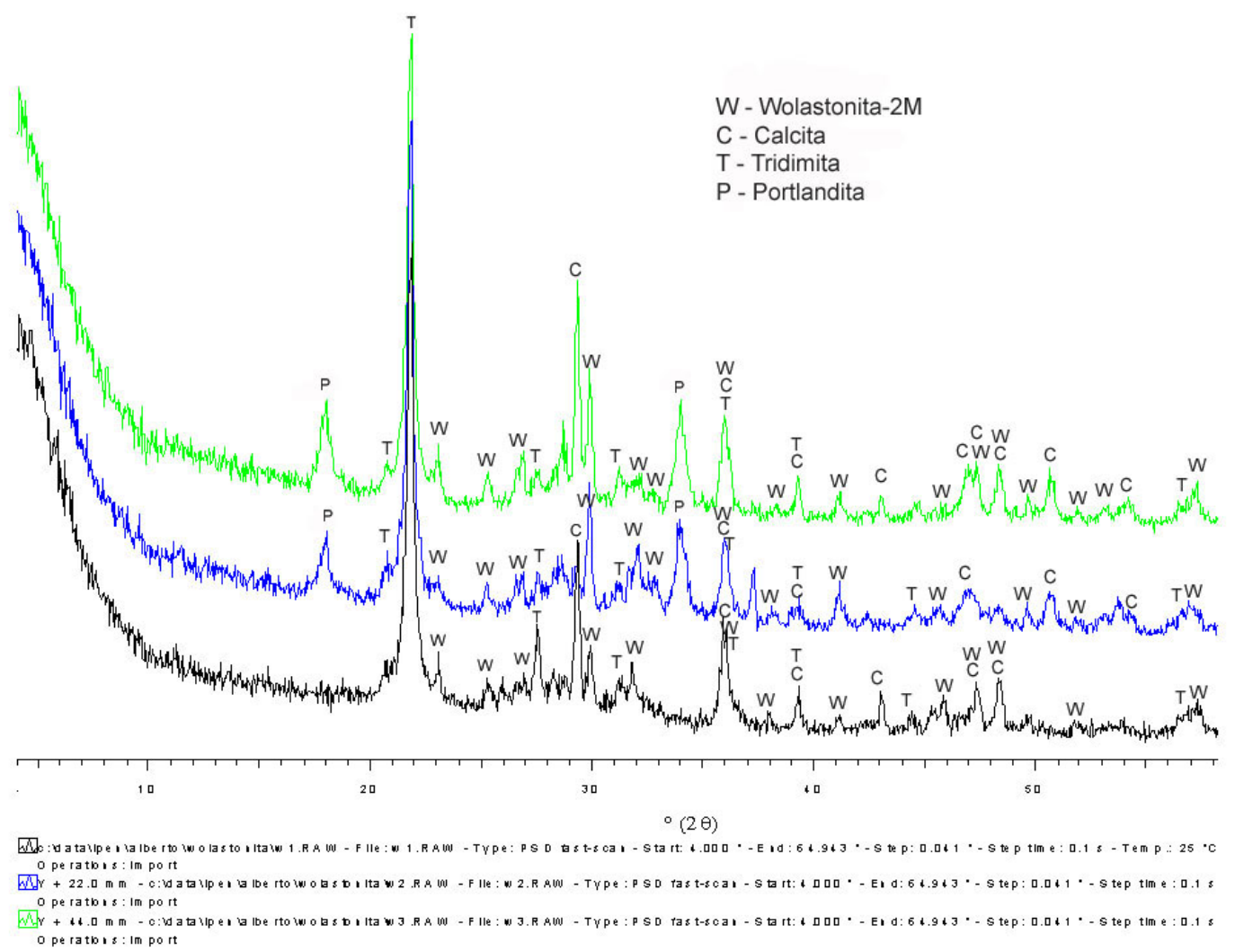

Figura 39: Difratogramas de raios $X$ das amostras W1 (preto), W2 (azul) e W3 (verde).

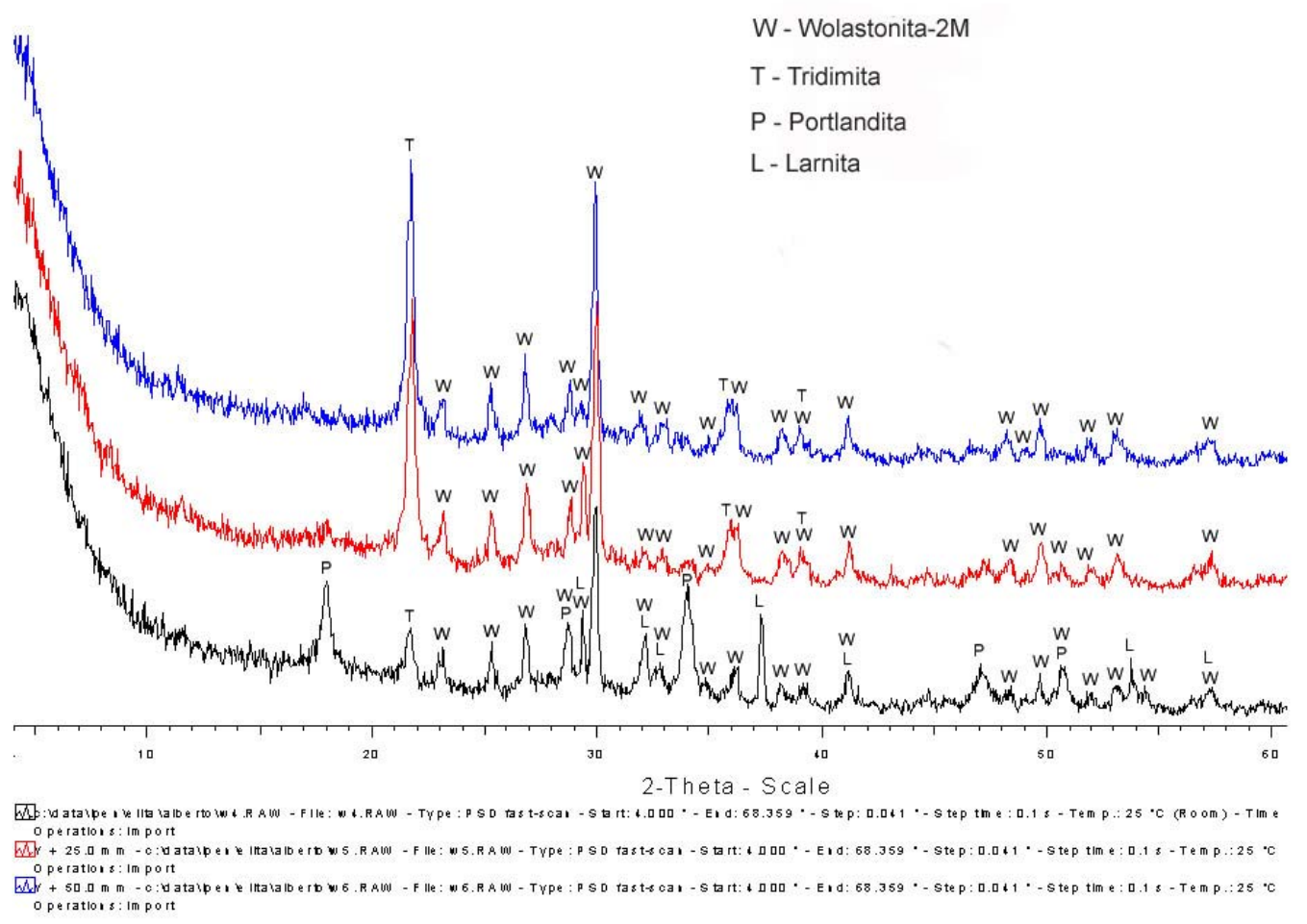

Figura 40: Difratogramas de raios $X$ das amostras W4 (preto), W5 (vermelho) e W6 (azul). 
Nas amostras W4, W5 e W6 (Figura 40) com a calcinação inicial do calcário de concha houve uma maior cristalização de wolastonita-2M, principalmente para as amostras W5 e W6.

$\mathrm{Na}$ amostra W4 houve formação de wolastonita-2M, $\mathrm{Ca}(\mathrm{OH})_{2}$ não reagido e Larnita $\left(\mathrm{Ca}_{2} \mathrm{SiO}_{4}\right)$.

Nas amostras W5 e W6 os picos da wolastonita-2M ficaram com maior intensidade e houve a formação também de tridimita $\left(\mathrm{SiO}_{2}\right)$, somente estas duas fases foram identificadas.

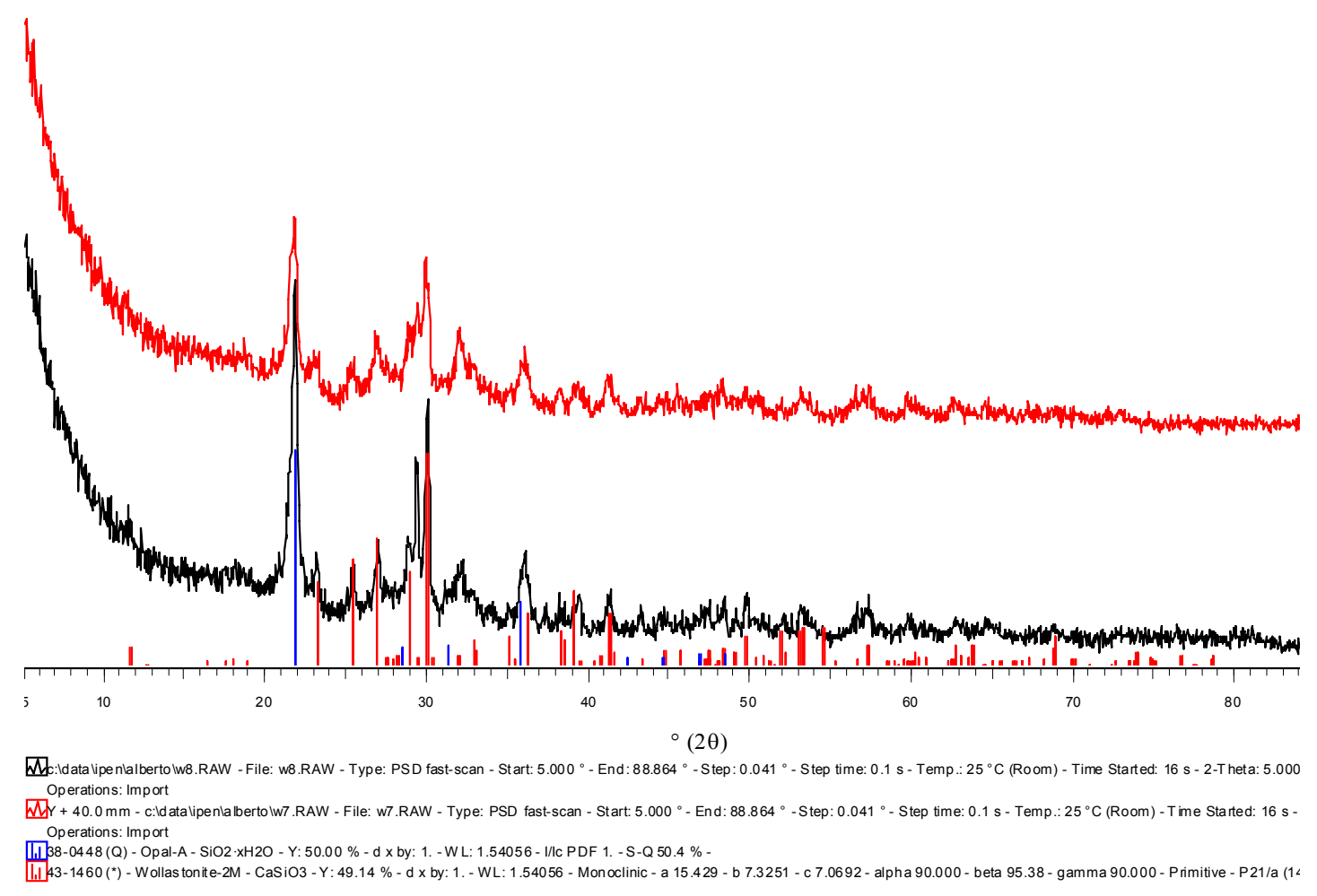

Figura 41: Difratogramas de raios $X$ das amostras W8 (preto) e W7 (vermelho). O padrão em vermelho é referente a fase wolastonita, e o azul, a fase tridimita.

Nas amostra W7 e W8 (Figura 41) e W9, houve forte formação de wolastonita-2M e tridimita. Os espectros são similares com as amostras W5 e W6. $\mathrm{Na}$ amostra W7 os picos de tridimita foram mais intensos.

$\mathrm{Na}$ amostra W10 os picos da wolastonita-2M ficaram muito bem definidos e com forte cristalinidade, houve uma formação pequena de tridimita (Figura 42).

As amostra W11, W12, W13 e W14 (Figura 43) apresentaram difratogramas semelhantes, com a formação, somente esta identificada, da fase wolastonita-2M com alta cristalinidade. 


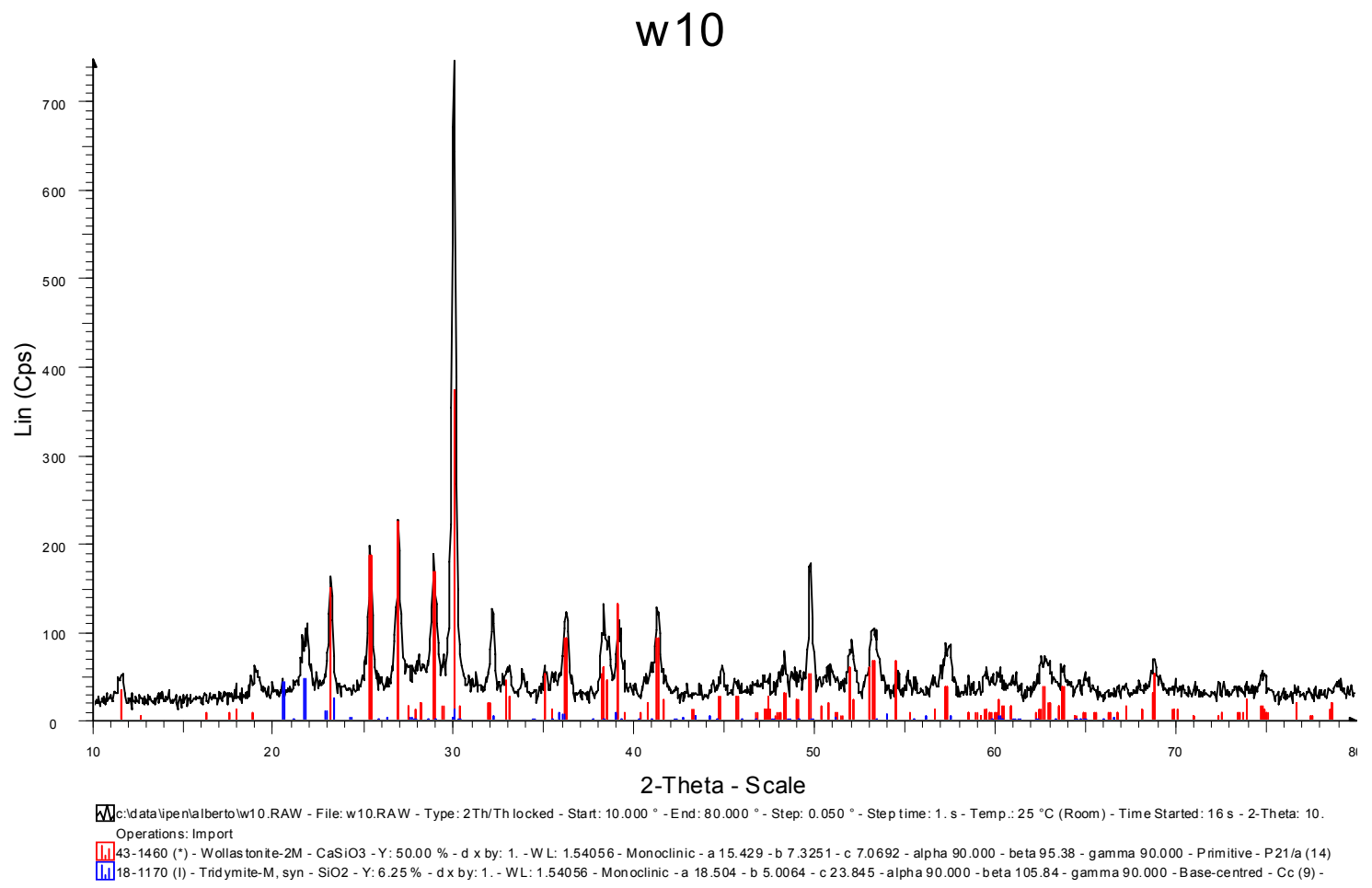

Figura 42 - Difratograma de raios $X$ da amostra W10. O padrão em vermelho é referente a fase wolastonita, e o azul, a fase tridimita.

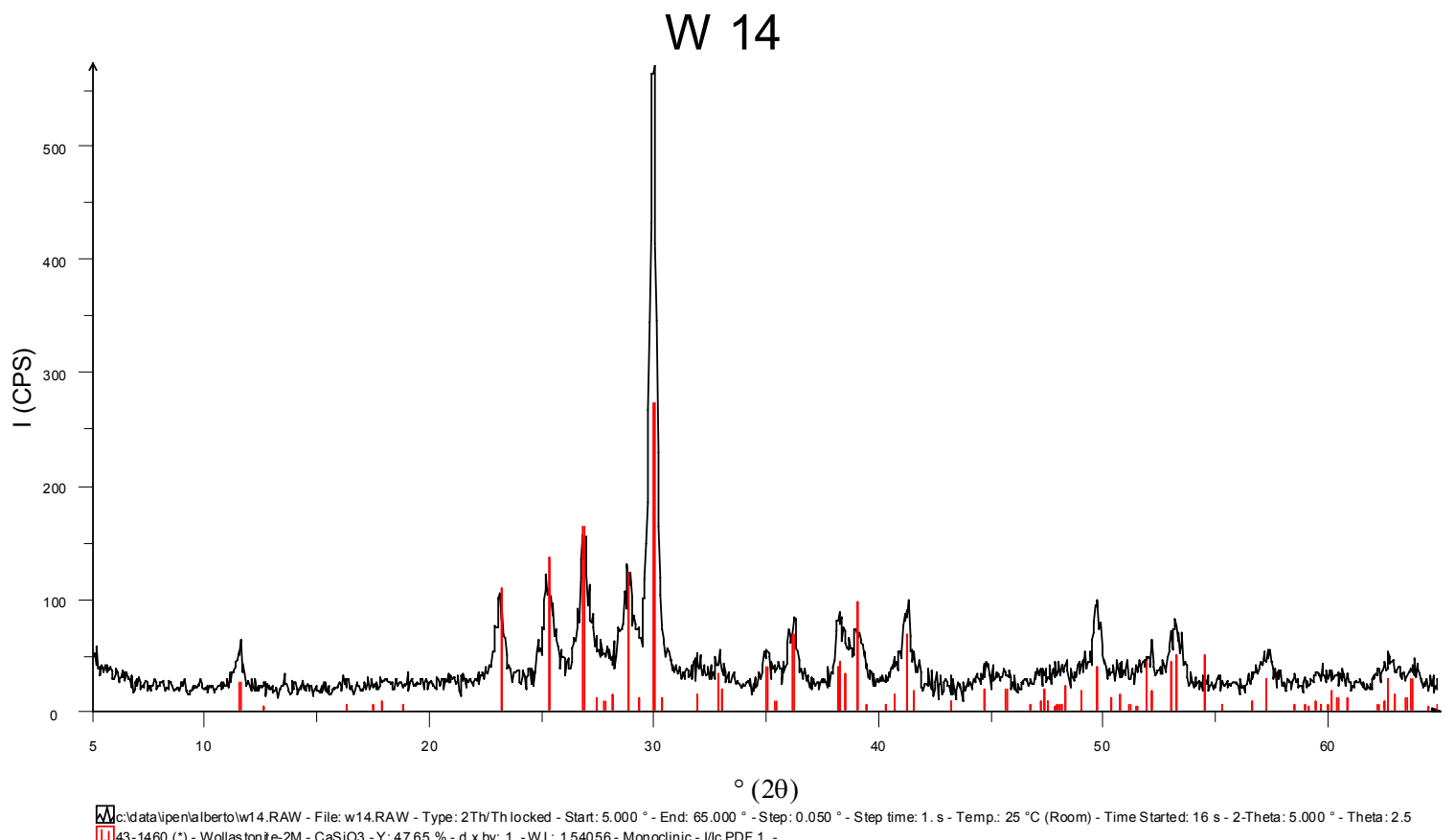

Figura 43 - Difratograma de raios $X$ da amostra W14. O padrão em vermelho é referente a fase wolastonita. 
Para as amostras W15, W16 e W17 houve a formação bem cristalina da fase wolastonita-2M, outras fases não foram identificadas nos difratogramas.

\subsubsection{Análise química quantitativa}

A análise química quantitativa das amostras W4 até W17 em relação a proporção em massa $\mathrm{SiO}_{2} / \mathrm{CaO}$ são mostradas no gráfico da Figura 44. A relação ideal é 1,07. As amostras W1, W2 e W3 não foram analisadas devido ao fato de formarem várias fases de acordo com a DRX. A concentração total de impurezas para todas as amostras não passou de 200 ppm. As amostras foram lavadas antes da análise química. Nas amostra W4, W5 e W6 houve uma grande concentração de $\mathrm{Na}(\sim 1 \%)$.

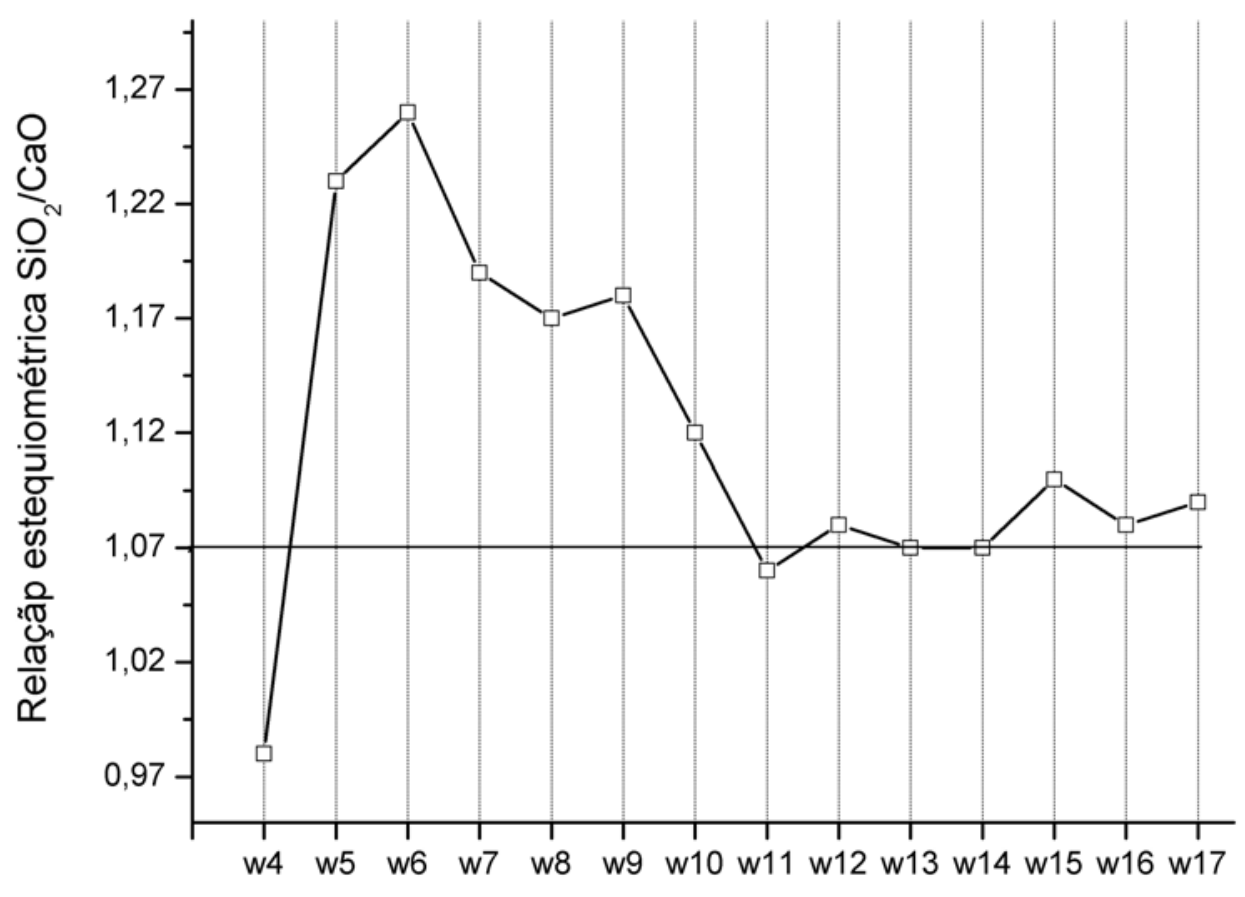

Amostra

Figura 44 - Gráfico representativo dos resultados obtidos de análise química quantitativa das amostras W4 até W17 em relação a proporção em peso $\mathrm{SiO}_{2} / \mathrm{CaO}$. Sendo 1,07 o valor teórico.

\subsubsection{Microscopia eletrônica de varredura (MEV)}

Foram tiradas fotografias de MEV nas amostra W4 até a amostra W17. Em todas as amostras o formato das partículas se apresentou igual, partícula arredondadas sem 
o caráter acicular da wolastonita natural (1A) e formando aglomerados que se desfazem com uma moagem.

Houve uma grande diferença no tamanho dos aglomerados entre o grupo de amostras W4-W9 e o grupo W10-W17. No último grupo em que houve o peneiramento os aglomerados foram maiores da ordem de $500 \mu \mathrm{m}$. E, no primeiro grupo foi da ordem de $30 \mu \mathrm{m}$.

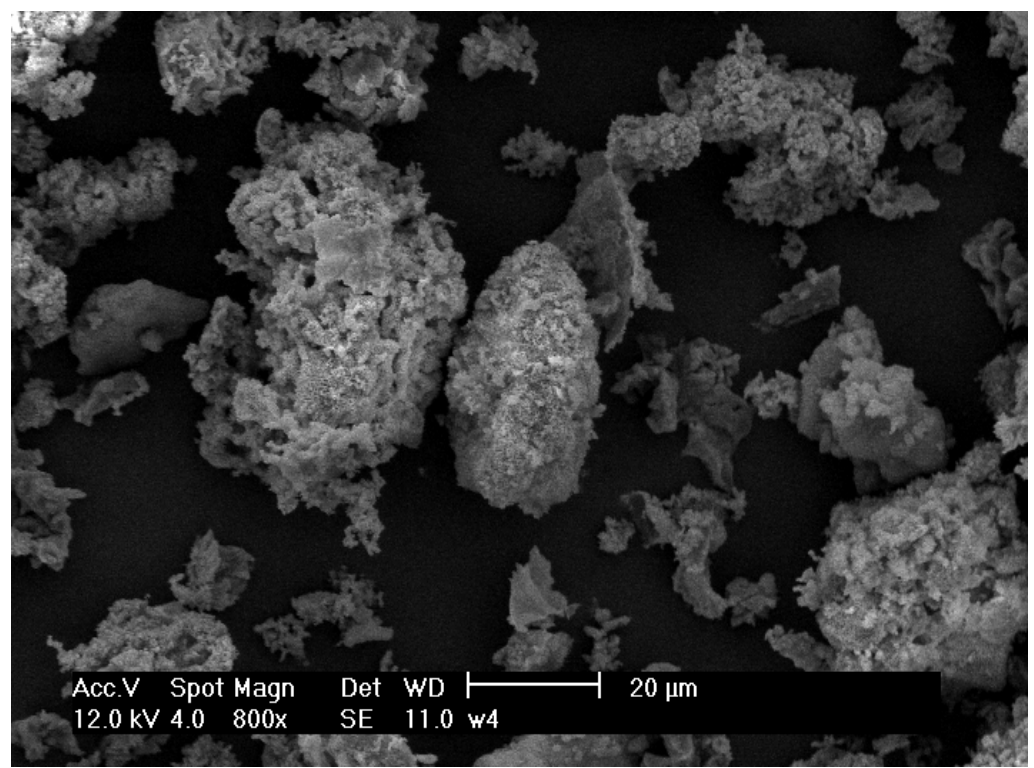

Figura 45 - Representação fotográfica de MEV da amostra W5 com aumento de 1600X.

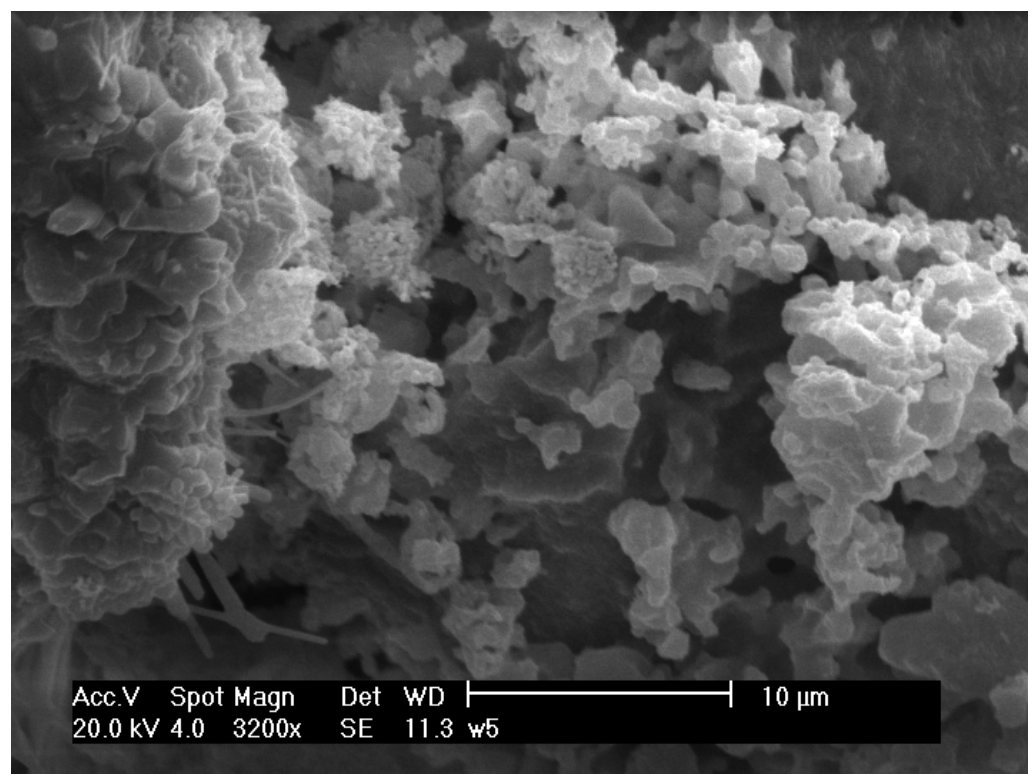

Figura 46 - Representação fotográfica de MEV da amostra W5 com aumento de 3200X. 


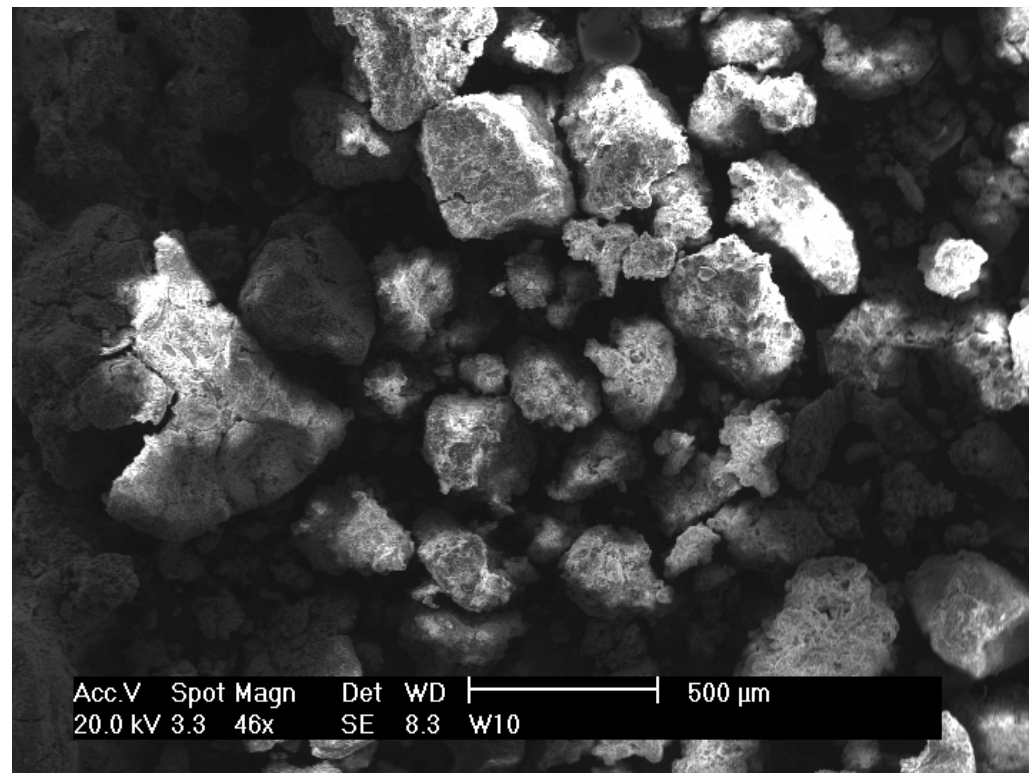

Figura 47 - Representação fotográfica da amostra W10 com aumento de 46X.

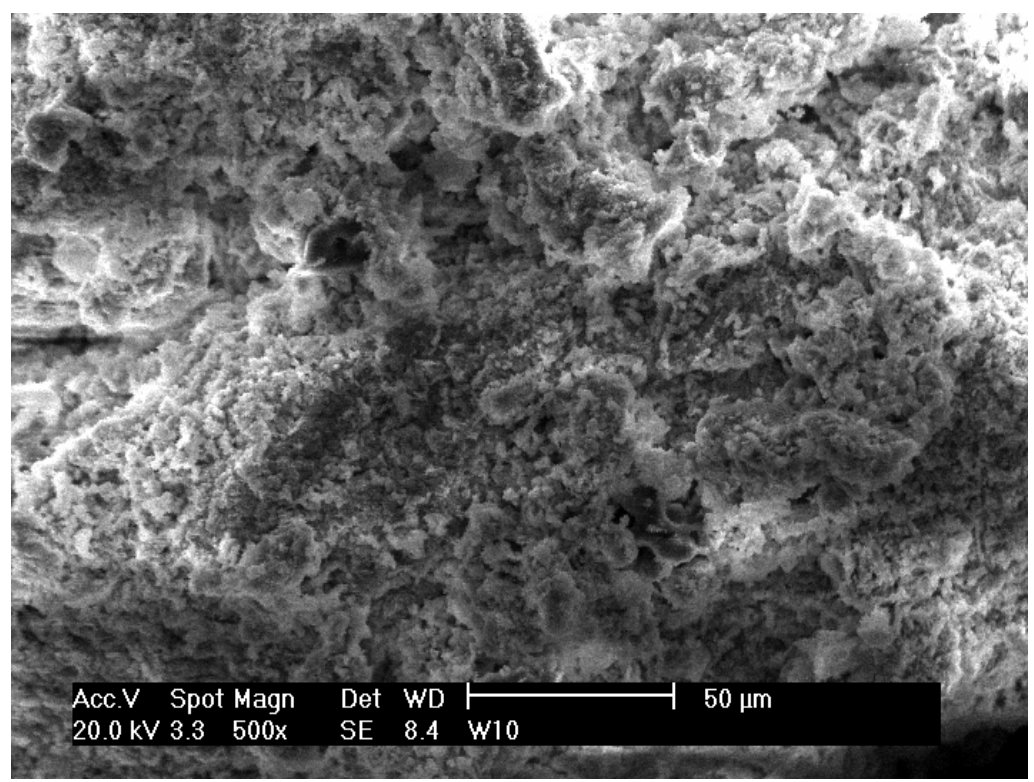

Figura 48 - Representação fotográfica da amostra W10 com aumento de 500X. 


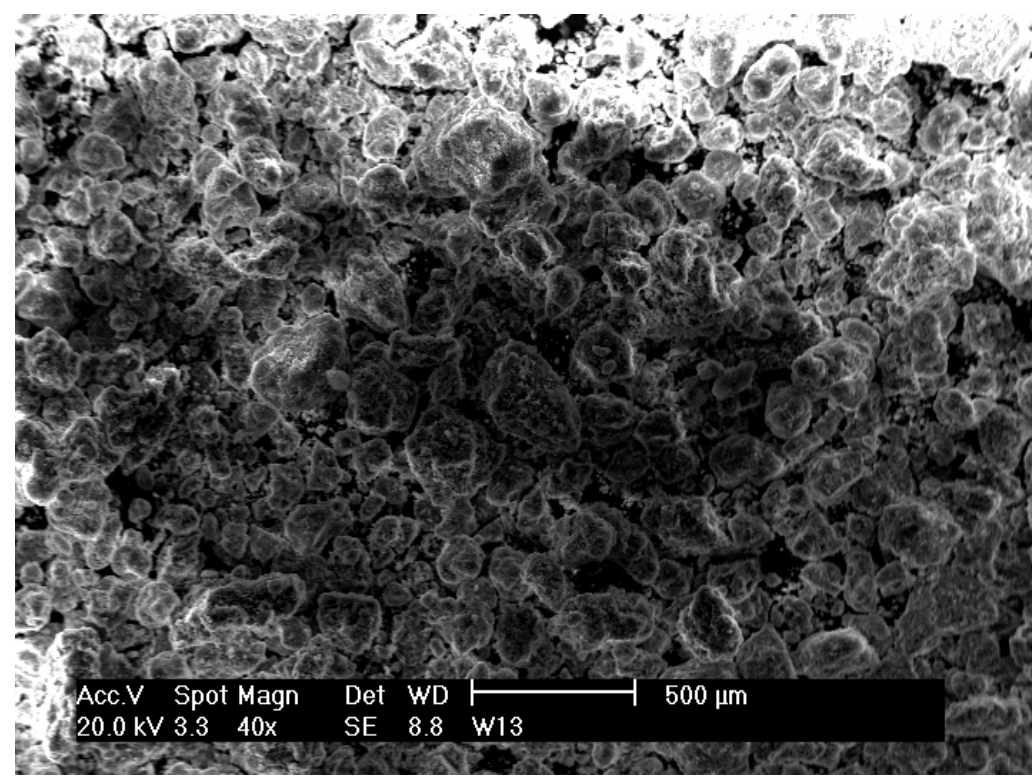

Figura 49 - Representação fotográfica da amostra W13 com aumento de 40x.

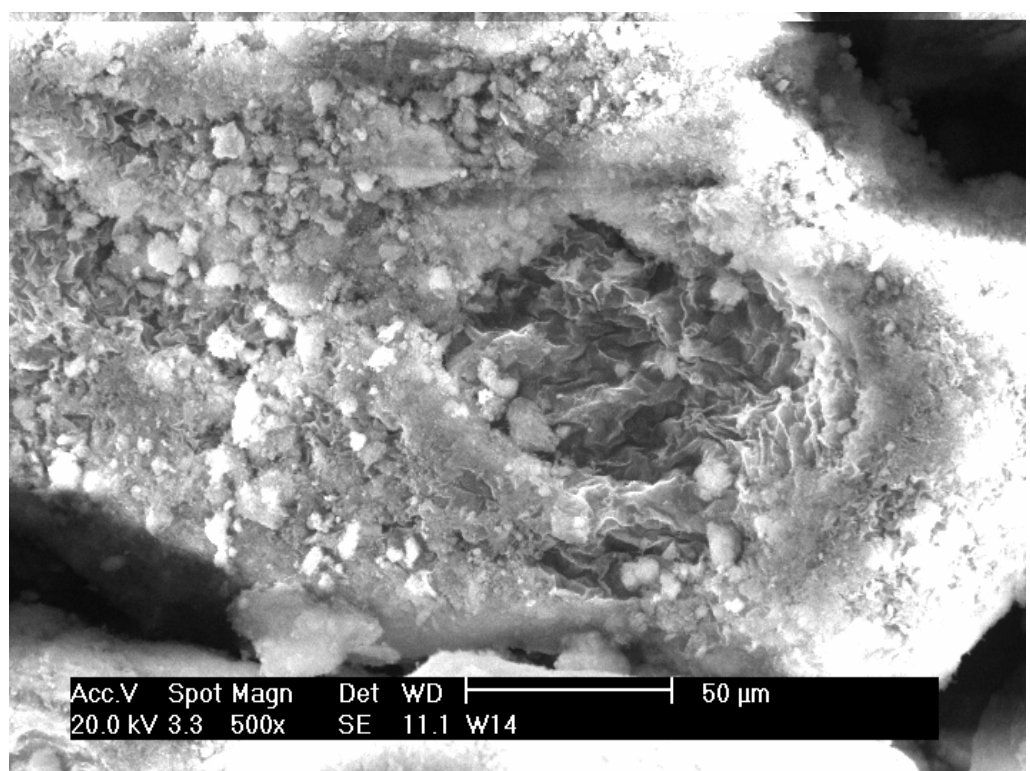

Figura 50 - Representação fotográfica da amostra W14 com aumento de 500x. 


\section{DISCUSSÃO}

\subsection{Extração da sílica da CCA}

A lixiviação da sílica com o hidróxido de sódio é governada pela seguinte equação:

$\mathrm{nSiO}_{2}+2 \mathrm{NaOH} \rightarrow \mathrm{Na}_{2} \mathrm{O} \cdot \mathrm{nSiO}_{2}+\mathrm{H}_{2} \mathrm{O}$

Em que o maior valor possível de $n$ é 3,8.

Na relação de extração 4:1 obtivemos um valor perto do ideal $(3,24)$, indicando uma grande eficiência de extração no aproveitamento da soda cáustica. Para relações maiores que $4: 1$, a porcentagem de massa reagida cai consideravelmente, tendo como resultado pouca eficiência. Junto a isto existem problemas operacionais como agitação e homogeneização da polpa.

Uma possível alternativa para se obter maior eficiência de extração é a lixiviação sob condições hidrotérmicas.

As condições de queima da casca, devem ser tal, que a fase orgânica se reduza ao máximo, isto é, com alta temperatura (o que cristaliza a sílica). A fase orgânica mostrou-se de fácil lixiviação, quando existente, resultando em uma cor âmbar na solução de silicato de sódio. Apesar da síntese da zeólita ZSM-5 (quando usando padrão) e wolastonita terem etapas de queima a temperaturas relativamente altas, o que eliminaria a fase orgânica proveniente da CCA, isto não acontece na zeólita A. Além do fato da fase orgânica influenciar a cinética e termodinâmica das reações resultando em produtos com menor cristalinidade e maior tempo de cristalização. Em um estudo sobre as condições ótimas de queima da casca, as variáveis importantes seriam: temperatura, tempo de queima e pressão parcial de oxigênio.

Existem estudos em que a fase orgânica é eliminada da CCA com uma lixiviação ácida antes da extração da sílica.

\subsection{Zeólita A}

Diferentes características do padrão de DRX do pó podem ser explorados na caracterização do material. É claro, os dados de difração são mais usados como uma "impressão digital" do material, mas outras informações podem se juntar conforme a Tabela 12. 
Neste trabalho pioneiro da síntese da zeólita A à partir da CCA, a alta reatividade da sílica coloidal extraída, mostrou-se efetiva na síntese.

Tabela 12 - Informações em um padrão de DRX.

\section{Característica}

Posição do pico $(2 \theta)$

Linhas não indexáveis

Ruído de fundo

Largura do pico

Intensidade do pico

\section{Informação}

Dimensão da célula unitária

Presença de impurezas cristalinas

Presença de material amorfo

Tamanho do cristalito

Tensão/deformação

Falha por empilhamento

Estrutura cristalina

A alta reatividade é evidente na amostra A4 em que o relativo pouco tempo de cristalização (12 h) já nucleia a segunda fase mais estável, a zeólita P. E em um tempo bem curto de cristalização para a amostra A5 (2h) têm-se quase a totalização da cristalização.

Foi sintetizada também na amostra $A 1$ a zeólita $X$, que tem grande interesse industrial. Uma evidência da alta reatividade da sílica gel é o fato da zeólita $\mathrm{X}$ cristalizar em 4 horas, tempo que na literatura, à $100^{\circ} \mathrm{C}$, não é maior que 8 horas para a completa cristalização.

A mistura do gel reacional objetivando uma completa homogeneização se torna evidente na amostra A6.

Nas fotos obtidas pelo MEV da amostra A3 (Figuras 30 e 31), os cristais de zeólita A estão bem cúbicos e definidos em concordância com a literatura. Com alguns cristais mostrando a "penetração casada" relacionada em uma rotação de $60^{\circ}$. Houve alguma formação de zeólita $P$ (partículas esferoidais), que pode ter cristalizado devido a picos de temperatura ou diferentes concentrações localizadas no gel reacional.

As partículas pequenas da maior parte das zeólitas sintéticas não são ideais para uso na maior parte das aplicações tradicionais, como resultado, o cristal deve ser agregado em partículas maiores policristalinas para ser usado em colunas de adsorção ou processos catalíticos. Partículas muito pequenas, ou nanocristais, tem despertado o interesse recente em aplicações de filmes e membranas. 


\subsection{ZSM-5}

A tentativa de síntese pelo método de Cardoso et al.(1995) (amostras Z1, Z2 e Z3) se mostrou infrutífero, não havendo cristalização. A sílica é atacada pelo $\mathrm{NaOH}$ formando silicato de sódio que permanece assim na mistura reacional, não havendo a formação do sol-gel reacional amorfo.

No ponto onde os reagentes da síntese são inicialmente misturados um gel visível é freqüentemente formado. Isto é descrito geralmente como a fase primária amorfa. Esta fase representa o produto inicial e imediato dos reagentes e está fora do equilíbrio, e provavelmente contendo produtos heterogêneos como: (a) aluminosilicatos precipitados amorfos, (b) sílica coagulada e alumina precipitada e (c) reagentes não modificados. $\mathrm{O}$ pH desta mistura não é usualmente uma medida útil, desde que ele depende de circunstâncias particulares e se modificará com o envelhecimento.

Após algum tempo, a mistura passará por transformações devido a reações de equilíbrio e é convertida a um estado intermediário chamado fase amorfa secundária. A relação entre as fases sólidas e líquidas aproximam-se de um equilíbrio e a distribuição característica dos ânions de silicato e aluminosilicato são estabelecidas. Na técnica de Cardoso a primeira fase sol-gel não se formou.

Com a precipitação da sílica, usando ácido sulfúrico, já a partir do experimento usando o silicato de sódio P.A. (amostras A, B, C e D-ZSM-5) é formado um gel compacto e reativo que resultou em amostras ZSM-5 bem cristalinas. Esta técnica da precipitação da sílica se mostrou também eficiente com as amostras usando o silicato de sódio da CCA. (amostras Zeo 1,2,3 e SILZ1, Z2 e Z3).

Nos difratogramas de DRX não houve uma diferença significativa nas amostras sintetizadas com o silicato comercial e o silicato obtido da CCA. O que foi conseguido com o silicato da CCA é a cristalização da ZSM-5 em tempo muito curto de envelhecimento (10 horas), tempo que na literatura não é menor que 40 horas.

A Tabela 11 mostra uma relação entre o aumento do tempo de envelhecimento com o aumento da área superficial específica e o volume de microporos, o que pode ser relacionado a maior concentração de núcleos formados. Não há nenhuma relação entre a composição química Si/Al e a área superficial específica. 
Apesar de dobrar a concentração de alumínio na mistura reacional entre os experimentos com silicato comercial (amostras AZSM-5 até DZSM-5) e utilizando a CCA (Zeo1 até 3 e SILZ1 até 3) a concentração de alumínio na zeólita aumenta, mas não dobra, mostrando que o núcleo é formado por tetraedros de sílica.

A morfologia dos cristais de ZSM-5 se mostrou de acordo com a literatura (Figura 51) com os referidos planos de clivagem. As amostras Zeo1, 2 (Figura 37) e 3 tiveram uma maior razão de aparência.
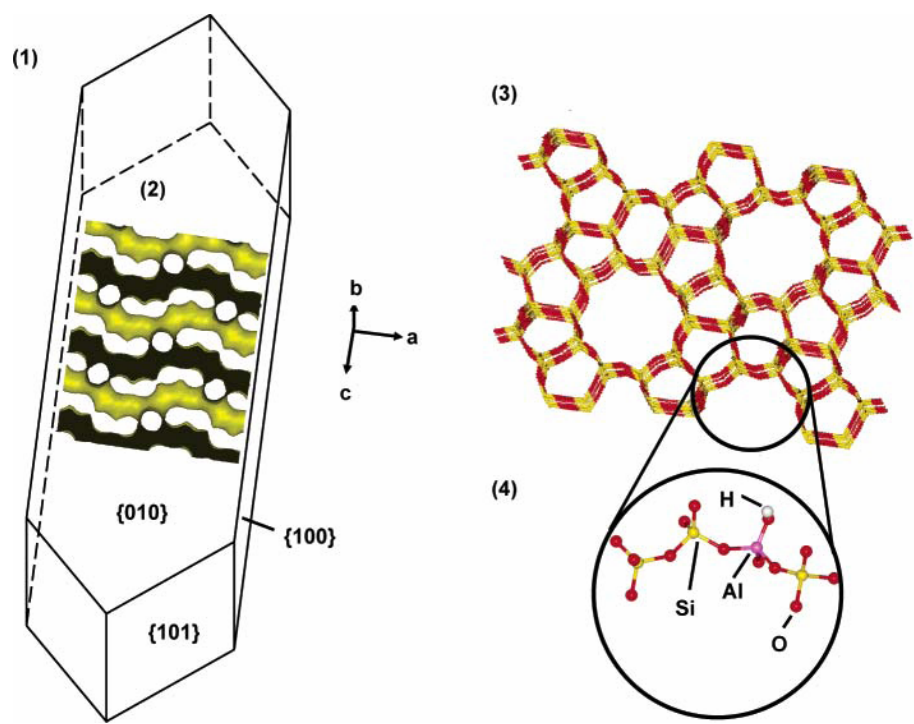

Figura 51 - Planos de clivagem do cristal de ZSM-5(Cundy \& Cox., 2003).

A razão de aparência do cristal de ZSM-5 é afetada pelas condições de reação, uma única face do cristal pode responder diferentemente a mudanças no sistema. Em uma composição constante um maior aumento na relação comprimento/largura são vistos com o aumento da temperatura de reação. $E$ mudanças similares também são função da composição. Nas amostras Zeo1, 2 e 3 uma maior concentração de Al pode ter fornecido a maior razão de aparência, fenômeno que não ocorreu nas amostras SILZ1, 2 e 3 devido ao pequeno tempo de envelhecimento.

O sucesso na síntese da ZSM-5, com relação $\mathrm{Si} / \mathrm{Al}>15$, sem o uso de padrão (amostras ETVI e ETVII) demonstra um processo inovador. O etanol não pode estar em grande concentração pois altera a química do sol-gel. O íon sulfato não se mostrou efetivo na síntese. 


\subsection{Wolastonita}

A calcinação do calcário de concha é uma etapa fundamental para se obter uma maior proporção final da fase wolastonita. O hidróxido de cálcio que se forma pela equação:

$\mathrm{CaO}+\mathrm{H}_{2} \mathrm{O} \rightarrow \mathrm{Ca}(\mathrm{OH})_{2}$

é fundamental na formação das fases xonolita e tobermorita que irão resultar na wolastonita durante o recozimento. Nas amostras W2 e W3 os picos de wolastonita estão mais evidenciados, mostrando que a temperatura de $830^{\circ} \mathrm{C}$ é baixa para o recozimento.

A alta reatividade da sílica amorfa obtida da CCA demonstrou ser extremamente eficiente em obter uma wolastonita com alto grau de cristalinidade.

Nas amostras W4, W5 e W6 notou-se as evidentes conseqüências de se fugir de uma mistura estequiométrica. A formação da larnita e a ausência da calcita na comparação entre as amostras W1,2,3 e W4,5,6 mostra a importância da decomposição do calcário de concha.

Na comparação das amostra W7 com a W8 e W9, a mistura e secagem a uma maior temperatura $\left(150^{\circ} \mathrm{C}\right)$, nas duas últimas, evidenciou picos de wolastonita maiores, mais definidos (mais linhas) e mais estreitos, indicando uma melhor temperatura para a formação das fases intermediárias. Apesar disto houve a formação de tridimita nas três amostras.

O tratamento hidrotermal em autoclave não se mostrou eficiente em maiores ganhos de cristalinidade e pureza da fase wolastonita até a amostra W9. A subtração desta etapa se mostrou evidente para todos estes experimentos e comparações.

Na comparação da amostra W10 com a W11 até a W14 o tratamento hidrotermal se mostrou eficiente na não formação da fase tridimita indesejada. Esta etapa junto com o controle do tamanho de partícula do $\mathrm{CaO}$ se mostrou eficiente na completa transformação das fases intermediárias que formam a wolastonita. Condições mais severas no tratamento hidrotermal não se mostraram efetivas.

Uma granulometria mais fina para o $\mathrm{CaO}$, nas amostras W15, 16 e 17, também não se mostrou melhor, do que a granulometria das amostras W11 até W14, para a formação da wolastonita pura. 
A morfologia arredondada, sem o caráter acicular, evidência a formação da wolastonita $2 \mathrm{M}$ em todas as fotos de MEV.

As amostras, em que o $\mathrm{CaO}$ foi peneirado, formaram aglomerados maiores (W10-17) no produto final. Isto pode ter ocorrido devido aos grão mais definidos, em virtude a um processo de crescimento mais homogêneo. 


\section{CONCLUSÕES GERAIS}

Os processos propostos para a produção de zeólita e wolastonita, minerais estes que a exploração é economicamente inviável no país, se mostraram efetivos. No caso das zeólitas sintetizadas neste trabalho elas só existem na versão sintética no mundo, não existindo similar natural.

O foco em processos simples e baratos, com o uso de um resíduo agro-industrial, se mostrou exeqüível.

Os objetivos deste trabalho tiveram as seguintes conclusões:

- A sílica coloidal obtida da CCA se mostrou com alta reatividade sendo possível seu uso em processos não antes imaginados. Sua obtenção com baixo custo energético e a partir de um resíduo danoso ao meio ambiente demonstra as grandes vantagens em seu uso.

- O sucesso no teste industrial da zeólita A, na Quimivale em Santa Catarina, na fórmula do sabão em pó, substituindo um material importado, demonstra a importância do trabalho para o país se levarmos em conta a abundância da matéria prima. Tendo como base os parâmetros usados na síntese dos $2 \mathrm{~kg}$ de zeólita A para testes industriais podemos fazer uma extrapolação em uma planta industrial tendo como insumo a CCA. Para se produzir uma tonelada de zeólita A seriam usados 2,2 ton de CCA, 0,92 ton de $\mathrm{NaOH}$ e 1,75 ton de aluminato de sódio.

- Na produção da zeólita ZSM-5, sem o uso de padrão e utilizando matéria prima de baixo valor, foi obtido um processo novo, que pode ser $70 \%$ mais barato que o processo tradicional. Este trabalho foi publicado na revista Materials Science Fórum - "A low coast ZSM-5 zeolite obtained from rice hull ash"Vols.498-499 (November 2005) pp.676-680-Trans Tech Publications, Switzerland.

- A síntese de wolastonita-2M, tendo como resultado somente esta fase é inédita. E o fato de ser quase completa, sem a etapa hidrotérmica, demonstra um processo de baixo custo, em que o sucesso se deve a alta reatividade da sílica coloidal da CCA. Técnica especiais de moagem podem tornar a morfologia da wolastonita com alta razão de aparência (comprimento/largura), que é necessária para algumas aplicações. 


\section{PERSPECTIVAS}

Como sugestões de trabalhos futuros pode-se citar:

- Estudo de técnicas mais efetivas na extração da sílica da CCA.

- Refinamento da caracterização da ZSM-5 sintetizada com etanol e testes como catalisador.

- Estudos da obtenção da wolastonita-2M sem a etapa hidrotérmica e com controle granulométrico dos reagentes.

- Testes industriais da wolastonita.

- Mensurar o grau de cristalinidade dos produtos obtidos pela técnica de comparação com amostra industrial. 


\section{REFERÊNCIAS BIBLIOGRÁFICAS}

Alizadeh, P.; Marghussian, V.; "Effect of nucleating agents on the crystallization behaviour and microstruture of $\mathrm{SiO}_{2}-\mathrm{CaO}-\mathrm{MgO}\left(\mathrm{Na}_{2} \mathrm{O}\right)$ glass ceramics", Journal of the European Ceramic Society -Vol.20, p-775-782 (2000).

Atalay, S.; Adiguzel, H.; Atalay, F.; "Infrared absorption study of $\mathrm{Fe}_{2} \mathrm{O}_{3}-\mathrm{CaO}-\mathrm{SiO}_{2}$ glass ceramics", Material Science and Engineering -Vol.304, p-796-799 (2001).

Baerlocher, C.; Meier, W.; Olson, D.; "Atlas of Zeolite Framework Types", 5th ed., Elsevier: Amsterdam, (2001).

Bauer, R.; Copeland, J.; Santini, K.; "Wollastonite", Industrial Minerals and Rocks, p-1119-1128 (1997).

Bedelean, I.; Ivan I.; Racatoian P.; "The production of synthetic wollastonite and diopside by using silica-rich natural raw materials", Tile \& Brick International- Vol. 16, No. 2 (2000).

Bransom, S.; Br. Chem. Eng. 5 , p-838 (1960).

Breck, D.; "Zeolite Molecular Sieves", Robert E. Krieger Publishing Company Malabar, Florida (1984).

Brinker, C.; Scherer, G.; "The physics and chemistry of Sol-Gel processing", Academic Press, San Diego CA, p-839-880 (1990).

Buckley, H.; "Crystal grow”; Wiley, New York, (1950).

Byrappa, K.; Yoshimura, M; "Handbook of hydrothermal technology", William Andrew Publishing, LLC - Norwich, New York. U.S.A. (2001).

Cardew, P.; Davey, R.; "Zeolite crystal grow”; Proc. R. Soc. London Ser. -398, p415 (1985).

Cardoso, D.; Almeida, F.; Francisco, R.; “Utilização de sílica dispersa na síntese da zeólita ZSM-5", Anais IBP -Vol.2, p-295-302 (1995).

Carvalho, C.; Silva, M.; Cardoso, M.; Cardoso, D.; "Influência dos Ânions na Síntese da Zeólita ZSM-5" $7^{\circ}$ Seminário Brasileiro de Catálise - IBP, p236-246. (1992).

Ciullo, P.; Robinson, S.; "Wollastonite a versatile functional filler", Paint \& Coating Industry - May (2002).

Coker, E.; Dixon A.; Sacco A.; "Zeolite synthesis in unstirred batch reactors II. Effect of non-uniform pre-mixing on the crystalliztion of zeolites $A$ and $X "$, Microporous Materials- Vol. 3, p-637-646 (1995).

Cook, J.; Thompson, R.; Zeolites 8 - p-322 (1988). 
Cox, P. Cundy, C.; "The hydrotermal synthesis of zeolites: Precursors, intermediates and reaction mechanism" Microporous Materials -Vol.82, p1-78 (2005).

Cundy, C.; Cox, P.; "The hydrotermal synthesis of zeolites: History and development from earliest days to the present", Chemical Review Vol.103, p-663-701 (2003).

Davies, C.; Jones, A.; "Crystal grow”; Trans. Faraday Soc.- 51, p-812 (1955).

Degnan T.; Chitnis G.; Schipper P.; "History of ZSM-5 Fluid Catalytic Cracking Additive Development at Mobil", Microporous and Mesoporous Materials - $\mathrm{n}^{\circ}$ 35-36, p-245-252 (2000).

Della, V.; Kühn, I.; Hortza, D.; "Caracterização de cinza de casca de arroz para uso como matéria-prima na fabricação de refratários de sílica”, Química Nova -Vol. 24, n6, p-778-782 (2001).

Dyer, A.; "An Introduction to Zeolite Molecular Sieves", John Wiley \& Sons University of Salford, Reino Unido (1988).

Falamaki, C.; Edrissi, M.; Sohrabi, M.; Zeolites 19, p-2 (1987).

Fernandes, V.; Pacheco, H.; Jewur, S.;"Síntese,e Caracterização e testes catalíticos das Zeólitas $A, X$ e $Y^{\prime \prime}, 3^{\circ}$ Seminário Brasileiro de Catálise IBP, p-297-311. (1988).

Folleto, E.; Kuhnen N.; José, H.; "Síntese da zeólita ZSM-5 e suas propriedades estruturais após troca iônica com cobre”, Cerâmica-Vol.46, p-300 (2000).

Glasser F.; Hong S.; "Phase relations in the CaO-SiO $-\mathrm{H}_{2} \mathrm{O}$ system to $200^{\circ} \mathrm{C}$ at saturated steam pressure ", Cement and Concrete Research - n ${ }^{\circ} 2483$, August (2003).

Gomes, R. C.; Visconte, L.L.; Furtado, C. R.; "Cinza da casca de arroz em composições poliméricas”, Revista de Química Industrial-ABQN $-\mathrm{n}^{\circ} 716$, p15-18 (2000).

Grieken R.; Sotelo J.; Melero J.; "Anomalous crystallization mechanism in the synthesis of nanocrystalline ZSM-5", Microporous and Mesoporous Materials - $n^{\circ} 39, p-135-147$ (2000).

Hahn A.; "Catalisadores: Crescimento dos zeólitos", Química e Derivados - Abril (2000).

Hamdan, H.; Ramli, Z.; Muhid, M.; “ ${ }^{29}$ Si MAS NMR, XRD and FESEM studies of rice husk silica for the synthesis of zeolites", Journal of Non-Crystalline Solides -Vol.211, p-126-131 (1997).

Holmes, D.; "Zeolites”, Industrial Minerals and Rocks, p-1129-1158 (1997). 
Ibañez A.; Sandoval F.; "Producing synthetic wollastonite by autoclaving", American Ceramic Society Bulletin - September (1998).

Iwamoto, M.; Mizuno, N.; Yahiro, H.; “Cu-ZSM-5” Journal of Japan Petroleum Institute -Vol.43 n5, p-375-390 (1991).

Kalapathy, U.; Proctor, A.; Shultz, J.; "A simple method for production of pure silica from rice hull ash”, Bioresource Technology -Vol.73, p257-262 (2000).

Kerr, G.; "Forty years of zeolite research" ,40 Seminário Brasileiro de Catálise IBP, p-1-15. (1989).

Kingery, W.; Bowen, H.; Uhlmann, D. "Introduction to ceramics”, Jonh Wiley \& Sons - MIT (1976).

Kotsis, L.; Balogh A.; "Synthesis of wollastonite", Ceramics International - Vol. 15, p-79-85 (1989).

Kühl, G.; "Source materials for zeolite synthesis", Verified Synthesis of Zeolitic Material - p-19-20 (2001).

Lai, R.; Gavalas, G.; "ZSM-5 membrane synthesis with organic-free mixtures", Microporous and Mesoporous Materials -Vol.38, p-239-245 (2000).

Lau, L.; Fernandes, S.; Nogueira, L.; "Estudo de Mecanismo de Formação de Zeolito tipo ZSM-5, o uso de CO-direcionador" ,4 ${ }^{\circ}$ Seminário Brasileiro de Catálise - IBP, p-12-23. (1989).

Lechert, $\mathrm{H}$.; "Possibilities and limitations of the prediction of the Si/Al ratios of zeolites from the batch composition", Microporous and Mesoporous Materials -Vol.40, p-181-196 (2000).

Lechert, H.; "The $\mathrm{pH}$-value and its importance for the crystallization of zeolites", Verified Synthesis of Zeolitic Material - p-33-38 (2001).

Lesley, S.; Moore, E.; "Solid State Chemistry and Introduction”, Chapman \& Hall London (1992).

Luz, A.; Damasceno, E.; "Zeólitas: propriedades e usos industriais", Brasil Mineral $-n^{0} 134, p-48-51$. (1995).

Mansaray, K.; Ghaly, A.; "Thermal degradation of rice husks in nitrogen atmosphere", Bioresource Technology-Vol.65, p-13-20 (1998).

Martinelli, J.; Bressiani, A.; "Síntese de materiais cerâmicos a partir da pirólise da palha de arroz", Anais do $9^{\circ}$ CBECIMAT, p-514-516. (1990).

Martinelli, J.; Bressiani, A.; Bonetti, M.; "Conversão de palha de arroz em nitreto de silício" , Anais do 10 CBECIMAT, p-126-128. (1992).

Mi, G.; Hanada M.; "Mechanochemical synthesis of tobermorite by wet grinding in a planetary ball mill", Powder Technology - Vol. 93, p-77-81 (1997). 
Mihailova, B.; Konstantinov, L.; Dinolova, E.; "Cluster-approximation modelling of infrared and Raman spectra of crystalline and vitreous $\mathrm{CaSiO}_{3}$ ”, Journal of Non-crystalline solids -Vol.191, p-79-84 (1995).

Miller, S.; "Method for Making ZSM-5 Zeolites", United States Patent - US 6,261,534 - Jul. 17 (2001).

Munhoz, A.; Rodrigues, S.; "Síntese e Caracterização de $\mathrm{NH}_{4} Z S M 5$ e sua utilização como catalisador", $\mathbf{7}^{0}$ Seminário Brasileiro de Catálise - IBP, p107-116. (1992).

Ohnemuller, W.; Solf, A.; "Synthetic wollastonite and a process for its manufacture", United States Patent - US 3,967,974 - July 6, (1976).

Persegil, M.; Souza, M.; Magalhães, W.; "Silica derived from burned rice hulls", Materials Research -Vol.5, $n^{\circ} 4, \mathrm{p}-467-474$ (2002).

Rabo, J.;"Zeolite Chemistry and Catalysis", American Chemical Society Washigton D.C. (1976).

Rakoczy, R.; Traa Y.; "Nanocrystalline zeolite A: synthesis, ion exchange and dealumination", Microporous and Mesoporous Materials - Vol. 60, p-6978 (2003).

Reiber, R.; Mallow, W.; Conner, J.; "Production of soluble silicates from biogenetic silica”, United States Patent - US 5,833,940 - November 10, (1998).

Rubin, M.; Rosinsky, E.; Plank, C.; "Synthesizing low Sodium Crystalline Aluminossilicate Zeolites with Primary Amines", United States Patent - US 4,151,189 - Apr. 24 (1979).

Sefcik, J.; McCormick, A.; "Prediction of crystallization diagrams for synthesis of zeolites", Chemical Engineering Science -Vol.54, p-3513-3519 (1999).

Souza, M.; Batista, P.; "Rice hull derived silica: Applications in Portland Cement and Mullite Whiskers", Materials Research -Vol.3, n², p-25-30 (2000).

Strassen, H.; Rauschenfels, E.; "Method for the production of synthetic wollastonite material”, United States Patent - US 4,165,991 - Aug. 28 (1979).

Stephens, D.; Wellen, C.; Smith, J; "Precipitated silicas, silicas gel with and free deposited carbon from caustic biomass ash solutions", United States Patent - US 6,375,735 - Apr. 23 (2002).

Thompson, R.; "Nucleation, growth, and seeding in zeolite synthesis", Verified Synthesis of Zeolitic Material - p-21-23 (2001).

Tome, R.; Tissler, A.; Schmidt, E.; "Synthetic Crystalline Aluminossilicate, method for its preparation as well as use", United States Patent - US 5,385,714 Jan. 31 (1995). 
Tsunematsu S.; Inoue H.; Yamada, H.; "Improvement of acid resistance of calcium silicate hydrate by thermal treatment", Cement and Concrete Research 34, pp-717-720 (2004).

Van Grieken, R.; Sotelo, J.; Menéndez J.; Melero J.; "Anomalous crystallization mechanism in the synthesis of nanocrystalline ZSM-5", Microporous and Mesoporous Materials -Vol.39, p-135-147 (2000).

Vempati, R; "ZSM-5 made from siliceous ash", United States Patent - US 6,368,571 - Apr. 9 (2002).

Virta R.; "Wollastonite", U.S. Geological Survey Minerals Yearbook - 2002.

Wilson, S.; "Templating in molecular sieve synthesis", Verified Synthesis of Zeolitic Material - p-27-31 (2001).

Withiam, M.; Conley, D.; Yannul, E.; "Calcium metasilicates and methods for making”, United States Patent - US 6,610,266 - Aug. 26 (2003). 
